
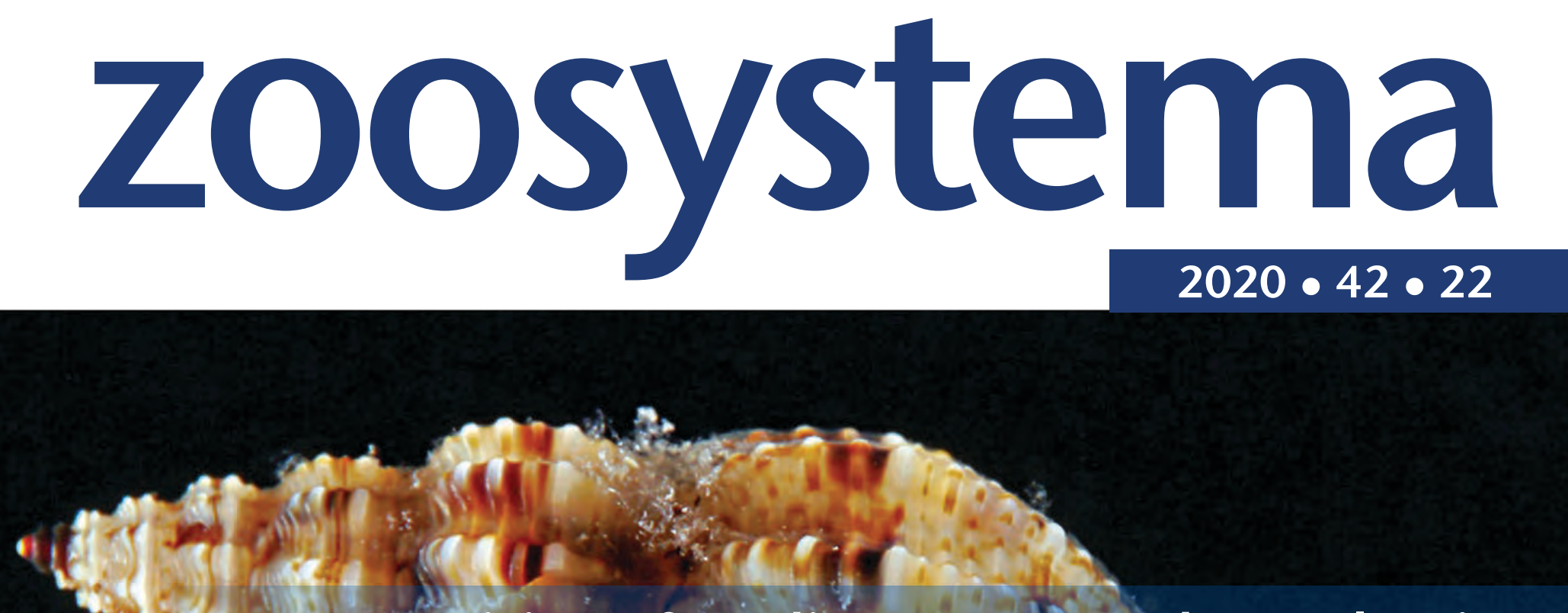

Revision of Mediterranean and NE Atlantic Raphitomidae (Gastropoda, Conoidea) 8: The genus Leufroyia Monterosato, 1884
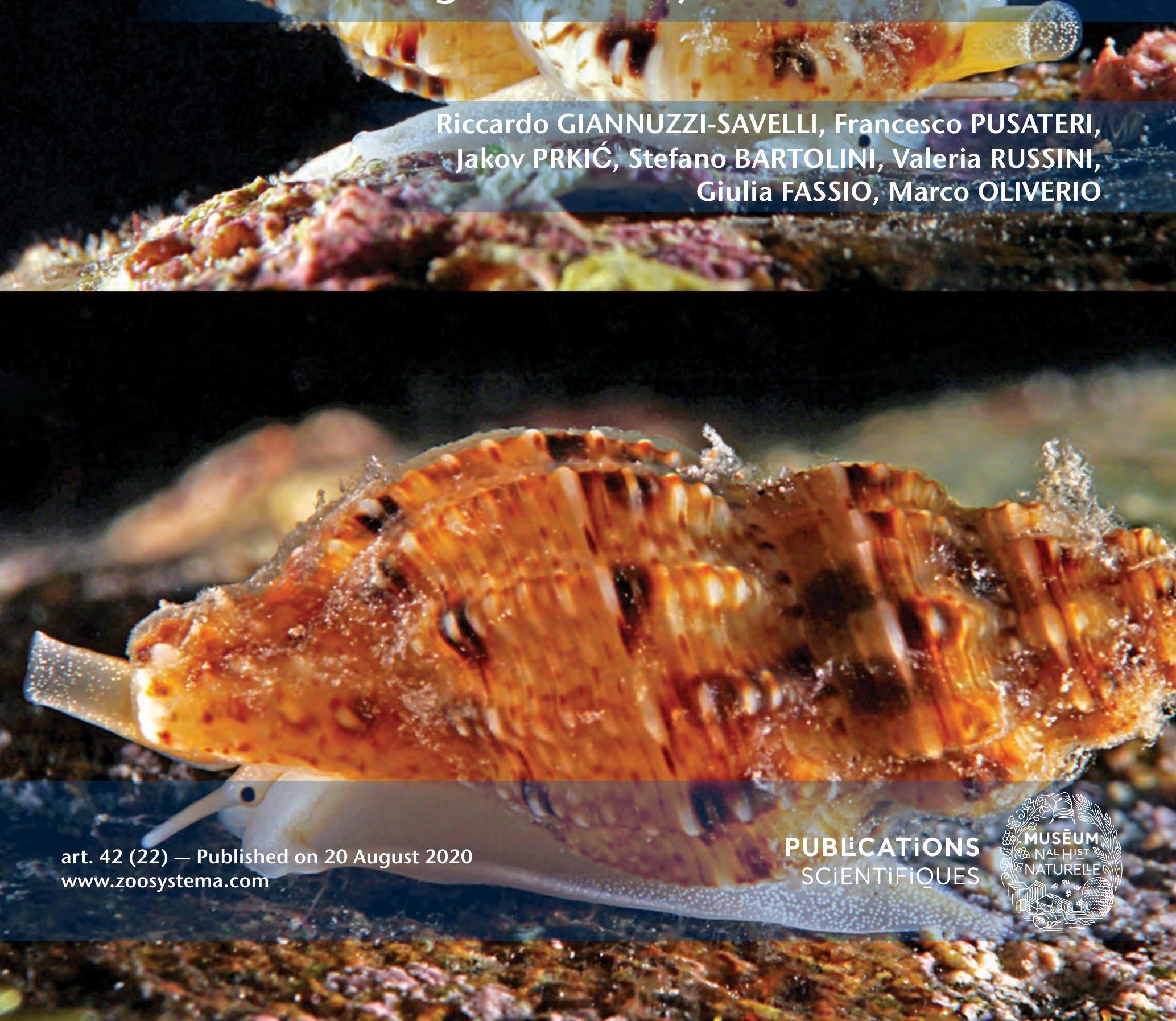
Directeur de LA publication / Publication diRECTOR: Bruno David

Président du Muséum national d'Histoire naturelle

RÉDACTRICE EN CHEF / EDITOR-IN-CHIEF : Laure Desutter-Grandcolas

AsSISTANTE DE RÉDACTION / AsSISTANT EDITORS: Anne Mabille (zoosyst@mnhn.fr)

Mise en PAge / Page Layout: Fariza Sissi

COMITÉ SCIENTIFIQUE / SCIENTIFIC BOARD:

James Carpenter (AMNH, New York, États-Unis)

Maria Marta Cigliano (Museo de La Plata, La Plata, Argentine)

Henrik Enghoff (NHMD, Copenhague, Danemark)

Rafael Marquez (CSIC, Madrid, Espagne)

Peter $\mathrm{Ng}$ (University of Singapore)

Norman I. Platnick (AMNH, New York, États-Unis)

Jean-Yves Rasplus (INRA, Montferrier-sur-Lez, France)

Jean-François Silvain (IRD, Gif-sur-Yvette, France)

Wanda M. Weiner (Polish Academy of Sciences, Cracovie, Pologne)

John Wenzel (The Ohio State University, Columbus, États-Unis)

COUVERTURE / COVER:

The raphitomid neogastropod Leufroyia leufroyi (Michaud, 1828). Two living specimens photographed in situ at Cap d'Antibes, France, 13-17 m depth.

Photo courtesy: Dominique Horst.

Zoosystema est indexé dans / Zoosystema is indexed in:

- Science Citation Index Expanded (SciSearch $\left.{ }^{\circledR}\right)$

- ISI Alerting Services ${ }^{\circledR}$

- Current Contents ${ }^{\circledR} /$ Agriculture, Biology, and Environmental Sciences ${ }^{\circledR}$

- Scopus ${ }^{\circledR}$

Zoosystema est distribué en version électronique par / Zoosystema is distributed electronically by:

- BioOne ${ }^{\circledR}$ (http://www.bioone.org)

Les articles ainsi que les nouveautés nomenclaturales publiés dans Zoosystema sont référencés par / Articles and nomenclatural novelties published in Zoosystema are referenced by:

- ZooBank ${ }^{\circledR}$ (http://zoobank.org)

Zoosystema est une revue en flux continu publiée par les Publications scientifiques du Muséum, Paris / Zoosystema is a fast track journal published by the Museum Science Press, Paris

Les Publications scientifiques du Muséum publient aussi / The Museum Science Press also publish:

Adansonia, Geodiversitas, Anthropozoologica, European Journal of Taxonomy, Naturae, Cryptogamie sous-sections Algologie, Bryologie, Mycologie, Comptes Rendus Palevol.

Diffusion - Publications scientifiques Muséum national d'Histoire naturelle

CP 41 - 57 rue Cuvier F-75231 Paris cedex 05 (France)

Tél. : 33 (0)1 40794805 / Fax: 33 (0)1 40793840

diff.pub@mnhn.fr / http://sciencepress.mnhn.fr

(C) Publications scientifiques du Muséum national d'Histoire naturelle, Paris, 2020

ISSN (imprimé / print) : 1280-9551/ ISSN (électronique / electronic): 1638-9387 


\section{Revision of Mediterranean and NE Atlantic Raphitomidae (Gastropoda, Conoidea) 8: The genus Leufroyia Monterosato, 1884}

Riccardo GIANNUZZI-SAVELLI Via Mater Dolorosa 54, 90146 Palermo (Italy) malakos@tin.it

Francesco PUSATERI

Via Castellana 64, 90135 Palermo (Italy) francesco@pusateri.it

Jakov PRKIĆ Getaldićeva 11, 21000 Split (Croatia) jakov.prkic1@inet.hr

Stefano BARTOLINI Via E. Zacconi 16, 50137 Firenze (Italy) stefmaria.bartolini@libero.it

\section{Valeria RUSSINI \\ Giulia FASSIO \\ Marco OLIVERIO}

Department of Biology and Biotechnologies "Charles Darwin”, Sapienza University of Rome, Viale dell'Università 32, 00185 Rome (Italy) valeria.russini@uniroma1.it giulia.fassio@uniroma1.it marco.oliverio@uniroma1.it (corresponding author)

Submitted on 5 March 2020 | Accepted on 6 July 2020 | Published on 20 August 2020

KEY WORDS

Northeastern Atlantic, Mediterranean Sea, integrative taxonomy.

MOTS CLÉS Atlantique Nord-Est, mer Méditerranée, taxonomie intégrative.
ABSTRACT
The four recent species of the genus Leufroyia Monterosato, 1884 are revised based on an integrative taxonomy approach: L. leufroyi (Michaud, 1828), L. concinna (Scacchi, 1836), L. erronea Monterosato, 1884 and L. villaria (Pusateri \& Giannuzzi-Savelli, 2008).

\section{RÉSUMÉ}

Révision des Raphitomidae de la Méditerranée et de l'Atlantique NE (Gastropoda, Conoidea) 8: Le genre Leufroyia Monterosato, 1884.

Les quatre espèces actuelles du genre Leufroyia Monterosato, 1884 sont révisées sur la base d'une approche de taxonomie intégrative : L. leufroyi (Michaud, 1828), L. concinna (Scacchi, 1836), L. erronea Monterosato, 1884 et L. villaria (Pusateri \& Giannuzzi-Savelli, 2008). 


\section{INTRODUCTION}

The Raphitomidae Bellardi, 1875 are a well-supported clade of the Conoidea Fleming, 1822 (Bouchet et al. 2011) worthy of family ranking. It is probably the most diverse family of Conoidea, in terms of species richness, ecological range and anatomical disparity (Kantor \& Taylor 2002). We are currently revising the Raphitomidae of the Mediterranean Sea and adjacent Atlantic coasts, which we provisionally estimated $c a .47$ Mediterranean extant species, some of which still undescribed. The taxon Raphitomidae Bellardi, 1875 is based on the genus Raphitoma Bellardi, 1847 which was introduced as comprising 34 fossil and Recent species (Bellardi, 1847: 85), previously classified in various genera (such as Pleurotoma Lamarck, 1799 and Clathurella Carpenter, 1857).

The systematics of several Mediterranean and North-East Atlantic conoidean species, traditionally ascribed to the genus Raphitoma Bellardi, 1847, have been revised by Fassio et al. (2019) based on molecular data. Three major lineages have been identified, considered as worthy of genus ranking: Raphitoma, Cyrillia Kobelt, 1905 and Leufroyia Monterosato, 1884. Here we have revised the Recent species of the genus Leufroyia Monterosato, 1884.

\section{MATERIAL AND METHODS}

Specimens studied in this work are housed in private and public collections. Many of the specimens were found alive, attached to the underside of small and mediumsized stones at $0-40 \mathrm{~m}$ depth, where they were manually collected during snorkelling or scuba diving. Empty shells were found crabbed mostly under stones at $0-40 \mathrm{~m}$ depth during diving, sorted out of bioclastic sediment samples collected manually at 1-30 m depth, by dredging from soft and mixed bottoms at 20-400 m depth, or in the residuals of material collected during red coral fishing at $60-100 \mathrm{~m}$ depth by scuba divers.

SEM images were taken with a Hitachi TM400 Plus by Nanovision s.r.l. (Brugherio). Light photographs were taken by the authors if not otherwise stated.

Scheme of the shell parameters are given in Fig. 1. The number of protoconch whorls has been counted according to the method of Verduin (1977).

The number of spiral cords on the body whorl, reported in this work, includes both cords and cordlets, and also threads on the subsutural ramp.

We have used a standardised format for the citation of specimen data in Type Material and Other Material Examined sections, as described by Chester et al. (2019).

\section{SPECIES DELIMITATION}

Most ITS-2 and COI sequences used in the present work, have been derived after the works by Fassio et al. (2019) and Russini et al. (2020). We have added hereby the sequences from additional specimens. DNA was extracted from a small piece of foot tissue using a modified Proteinase k-Phenol-Cloroform protocol (Oliverio \& Mariottini, 2001). We amplified one nuclear marker (the internal transcribed spacer 2 of the ribosomal cluster, ITS2, $-500 \mathrm{bp}$ with primers ITS-3d and ITS-4r (Oliverio \& Mariottini 2001)), and the mitochondrial cytochrome $c$ oxidase subunit I (COI), with primers LCO1490 and HCO 2198 (Folmer et al. 1994), corresponding to the standard barcode fragment $(658 \mathrm{bp}$ ) or with primers HCO2198 and mlCOIint-F (5'-GGWACWGGWTGAACWGTWTAYCCYCC-3') designed to amplify a shorter fragment (ca. $300 \mathrm{bp}$ ) and employed in meta-barcoding works (Leray et al. 2013). PCR product were purified using Exosap-IT (USB Corporation) and Sanger sequenced by Macrogen Inc. (Spain).

Sequences were aligned using Geneious 11 (Kearse et al. 2012) or the online version of MAFFT 7 (Katoh et al. 2017; Kuraku et al. 2013) with the Q-INS-I algorithm. Intraspecific genetic distance for each putative species were estimated with MEGA 7 (Kumar et al. 2016), with the Kimura-2 parameters (K2p) model for easier comparison with standard DNA-barcoding studies.

We have adopted here an Integrative Taxonomy approach: all shells and live collected specimens were preliminarily defined by using shell characters to identify putative species (Preliminary Species Hypotheses, PSH), based on the most recent taxonomy of the group (Giannuzzi-Savelli et al. 2017, 2018a, 2018b; Pusateri et al. 2012, 2013, 2016, 2018). The PSH were then tested by a multi-step molecular approach: 1 ) the distance-based Automatic Barcode Gap Discovery (ABGD, available at https://bioinfo.mnhn.fr/abi/public/abgd/), was used to group specimens after an analysis of the distribution of pairwise distances in a COI alignments (Puillandre et al. 2012); 2) the species hypotheses retained aftert the ABGD analyses were eventually tested for their reciprocal monophyly by performing Maximum Likelihood (ML) and Bayesian inference (BI) phylogenetic analyses on single-gene alignments and on a concatenated dataset (COI + ITS2), using Conus consors G.B. Sowerby I, 1833 and C. bandanus Hwass in Bruguière, 1792 as outgroup for the Raphitomidae (Nam et al. 2009); 3) diagnostic nucleotides were identified on the COI and the ITS2 alignments by the r-package SPIDER (Brown et al. 2012). Nodes with Bootstraps support (BS) of $70-90 \%$ and Posterior Probabilities (PP) of 0.90-0.95 have been considered as moderately supported; BS $>90 \%$ and PP $>0.95$ have been considered as highly supported (Hillis \& Bull 1993; Alfaro \& Holder 2006).

\section{ABBREVIATIONS}

\section{Institutions}

BAU

CGS

HUJ

MCZR

MNHN

MDCL
Department of Biology and Biotechnologies, 'Sapienza' University, Rome;

Can Geyran Seashells Center, Istanbul;

Hebrew University, Jerusalem;

Museo Civico di Zoologia, Roma;

Musée Nationale Histoire Naturelle, Paris;

Musée des Confluences, Lyon; 


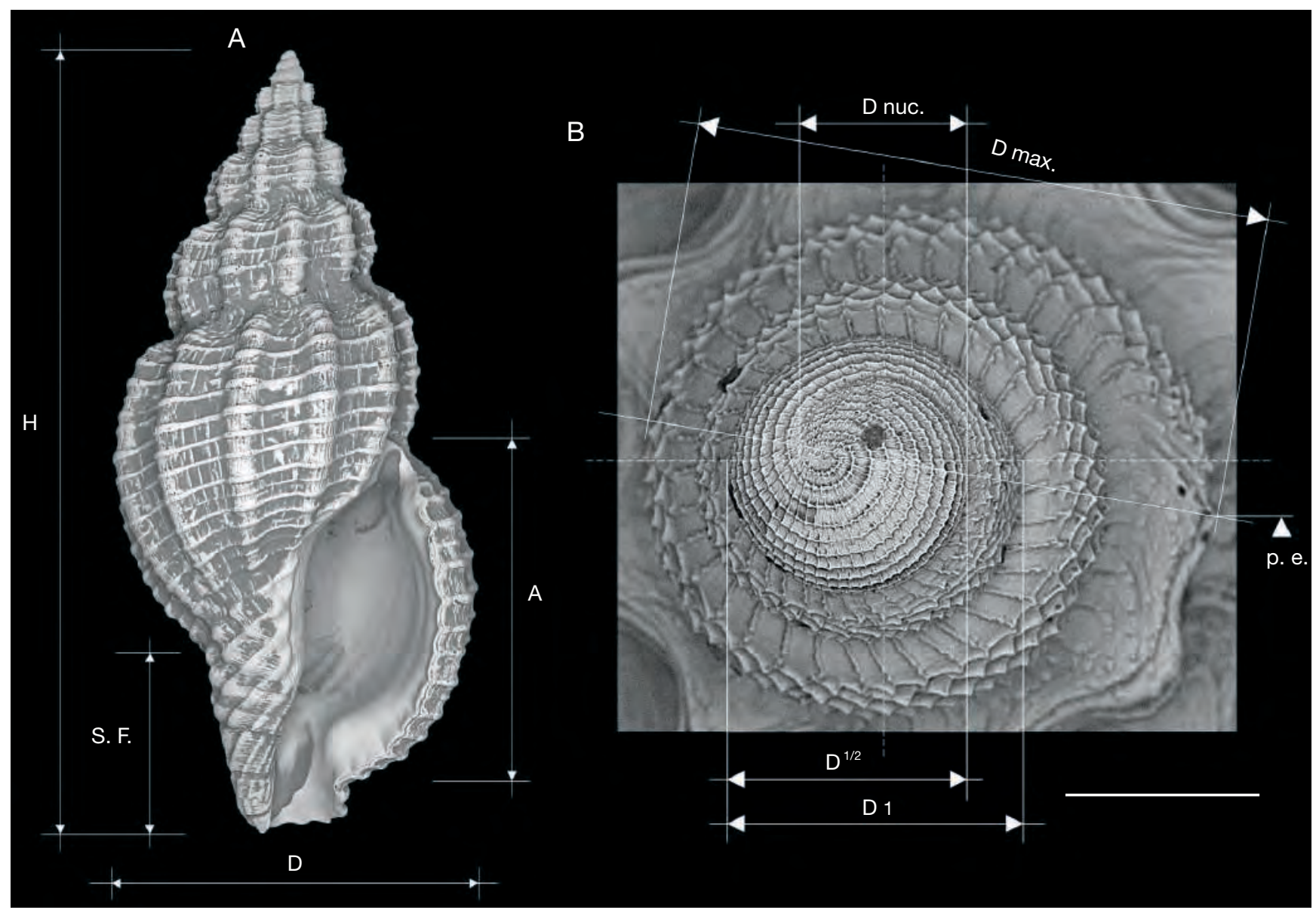

FIG. 1. - A, Scheme of the shell parameters. B, measurements taken on protoconch (according to Verduin 1977). Abbreviations: A, aperture; W, width; $\mathrm{H}$, height; S. F., siphonal fasciole; Dnuc, diameter of nucleus; D1/2, diameter of first half-whorl; D1, diameter of first whorl; max. D, maximum diameter; p.e., protoconch end. Scale bar: $200 \mu \mathrm{m}$.

MHNG Muséum d'histoire Naturelle de Genève, Genève; MRSNT Museo Regionale Storia Naturale, Terrasini, Palermo; NMR Natural History Museum, Rotterdam;

NMW National Museum of Wales, Cardiff;

SMNH Swedish Museum of Natural History, Stockholm;

USNM United States National Museum (Smithsonian),

ZMBN Zoological Museum, Bergen.

\section{Private collections}

coll. AGA Franco Agamennone, Pescara;

coll. ARD Roberto Ardovini, Roma;

coll. BAL Giovanni Balena, Livorno;

coll. BAR Stefano Bartolini, Firenze;

coll. BIN Gianluigi Bini, Città di Castello;

coll. CAM Enzo Campani, Livorno;

coll. CAR Alberto Caruso, Sapri;

coll. CRO Paolo Crovato, Napoli;

coll. DIN Antonio Di Nisio, Pescara;

coll. DSC Christiane Delongueville \& Roland Scaillet, Bruxelles;

coll. DUR Sergio Duraccio, Napoli;

coll. FEN David Fenwick, Penzance;

coll. FIO

coll. FUM

Angelo Fiorita, Porto Cesareo;

coll. GER

Bruno Fumanti, Sabaudia;

coll. GIR coll. GON coll. GOR coll. GUB coll. HOA coll. HOU coll. KEL coll. KON coll. LET coll. MAC coll. MAR coll. MEL coll. MIF coll. NAP coll. NOT coll. OCC coll. OLI coll. OZT coll. PAG coll. PAO coll. PIE coll. PIS coll. PRK coll. PUS coll. REP coll. RON coll. SER coll. SMR coll. SPM
César Fernandez Gonzàlez, Vigo;

Sandro Gori, Livorno;

Franco Gubbioli, Marbella;

André Hoarau, Fréjus;

Juan Horro, Vigo;

Lars David Kellner, Munich;

Costas Kontadakis, Athens;

Neven Lete, Split;

Gabriele Macrì, Scorrano;

Alessandro Margelli, Santa Maria a Monte;

Nicola Melone, Giovinazzo;

Constantin Mifsud, Rabat, Malta;

Andrea Nappo, Pomezia;

Giuseppe Notaristefano, Milazzo;

Rosario Occhipinti, Ragusa;

Marco Oliverio, Roma;

Bilal Oztürk, Izmir;

Attilio Pagli, Sovigliana;

Paolo Paolini, Livorno;

Angela Pierullo, Anzio;

Michele Pisanu, Cagliari;

Jakov Prkić, Split;

Francesco Pusateri, Palermo;

Gianni Repetto, Alba;

Francesco Roncone, Cosenza;

Gabriele Sercia, Roma;

Carlo Smriglio, Roma;

Maria Teresa Spanu, Alghero; 
A

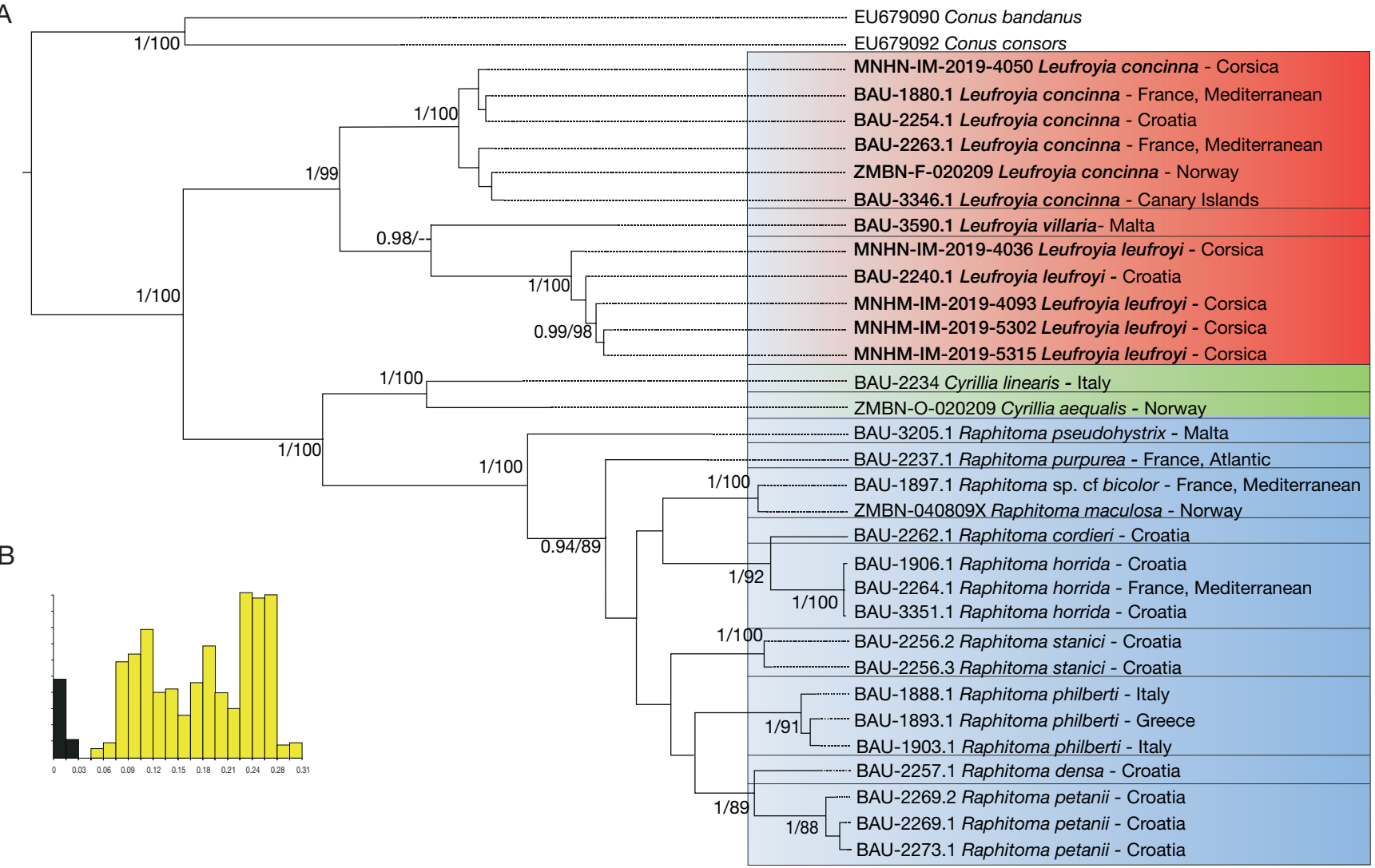

FIG. 2. - Relationships and genetic divergence among species of Raphitomidae Bellardi, 1875. A, Bayesian topology on the COI alignment. Numbers at nodes are posterior probabilities after a Bayesian analysis, and bootstrap supports after Maximum likelihood analysis on 1000 pseudoreplicates; only values higher than $75 \%$ bootstrap support and 95\% posterior probability are reported. The boxes comprise the species hypotheses as defined by the ABGD analysis. B, Distribution of the pairwise genetic distances $(\mathrm{K} 2 \mathrm{p})$ among the $\mathrm{COI}$ sequences (black bars on the left, intraspecific comparisons; on the right, interspecific comparisons).

coll. STA

coll. STH

coll. TIS

coll. TRI

coll. UGA

coll. VAZ

Rino Stanić, Split;

Peter Stahlschmidt, Rohrbach

Morena Tisselli, San Zaccaria;

Lionello Tringali, Roma;

Pero Ugarković, Split;

Angelo Vazzana, Reggio Calabria.

$\begin{array}{ll}\text { Morphometrics (Fig. 1) } \\ \text { H } & \text { height; } \\ \text { H/W } & \text { height/width ratio; } \\ \text { PW } & \text { protoconch whorls; } \\ \text { SD } & \text { Standard Deviation; } \\ \text { TW } & \text { teleoconch whorls; } \\ \text { W } & \text { width. }\end{array}$

\section{RESULTS}

SPECIES DELIMITATION

For this work we obtained only the shorter COI barcode sequences (ca. $300 \mathrm{bp}$ ) from a specimen (BAU 3590.1) morphologically identified as Leufroyia villaria (Pusateri \& Giannuzzi-Savelli, 2008) from Malta and from a specimen (BAU 3346.1) from Canary Islands of uncertain morphological identification. Furthermore, we obtained an ITS-2 sequence from the specimen BAU 3590.1. These sequences, along with $5 \mathrm{COI}$ barcode sequences (658 bp) from Corsican specimens (provided by Nicolas Puillandre, MNHN), were eventually aligned with sequences from GenBank (after Fassio et al. 2019 and Russini et al. 2020), and used for a molecular phylogenetic analysis of all available Leufroyia sequences. The new sequences (seven COI and one ITS2) have been deposited in GenBank (acc. nos. MT611531, MT606166, MT606167, MT606161-MT606165).

The recursive ABGD analysis on the COI alignment identified 3 putative species (Fig. 2) among the assayed Leufroyia specimens. In particular, the specimen BAU 3590.1 morphologically identified as L. villaria was consistently regarded as distinct from Mediterranean specimens identified as L. leufroyi (Michaud, 1828) (BAU 1742.1, BAU 2240.1, MNHN-IM-2019-4036, MNHN-IM-2019-4093, MNHNIM-2019-5302, MNHN-IM-2019-5315) and from Mediterranean and Atlantic specimens identified as L. concinna (Scacchi, 1836) (Mediterranean: BAU 2237.1, BAU 2254.1, MNHN-IM-2019-4050; Atlantic: ZMBN 020209-F, ZMBN E-23-67, ZMBN H-3-69a). The last group included also the specimen BAU 3346.1 from Canary Islands, of uncertain morphological identification

In the phylogenetic analyses, the single-gene and combineddataset trees showed broadly similar topologies (Figs 2, 3), with only lower node support values in the single-gene trees. Leufroyia was consistently monophyletic, including also 
A

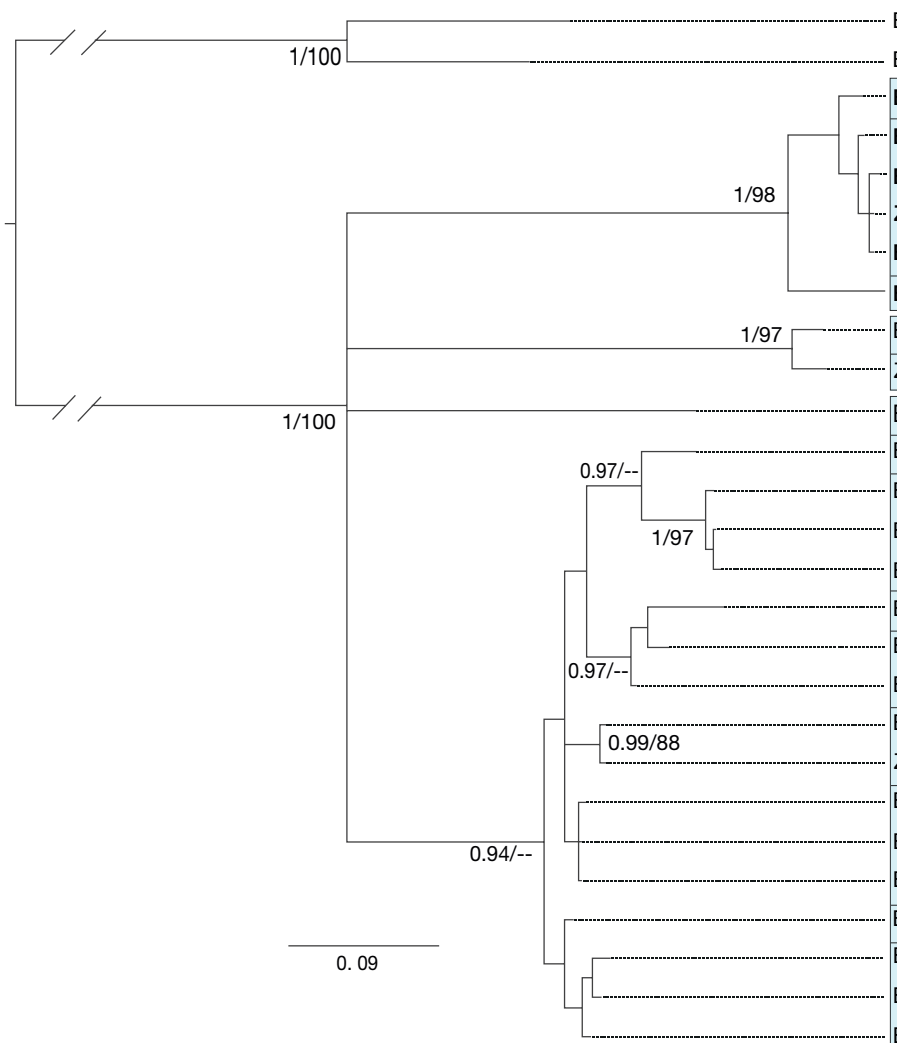

EU679090 Conus bandanus EU679092 Conus consors

BAU-3590.1 Leufroyia villaria- Malta

BAU-2254.1 Leufroyia concinna - Croatia

BAU-2263.1 Leufroyia concinna - France, Mediterranean

ZMBN-F-020209 Leufroyia concinna - Norway

BAU-1880.1 Leufroyia concinna - France, Mediterranean

BAU-2240.1 Leufroyia leufroyi - Croatia

BAU-2234 Cyrillia linearis - Italy

ZMBN-O-020209 Cyrillia aequalis - Norway

BAU-3205.1 Raphitoma pseudohystrix - Malta

BAU-2262.1 Raphitoma cordieri - France, Mediterranean

BAU-1906.1 Raphitoma horrida - Croatia

BAU-2264.1 Raphitoma horrida - France, Mediterranean

BAU-3351.1 Raphitoma horrida - Croatia

BAU-2237.1 Raphitoma purpurea - France, Atlantic

BAU-2256.2 Raphitoma stanici - Croatia

BAU-2256.3 Raphitoma stanici - Croatia

BAU-1897.1 Raphitoma sp. cf bicolor - France, Mediterranean

ZMBN-040809X Raphitoma maculosa - Norway

BAU-1903.1 Raphitoma philberti - Italy

BAU-1893.1 Raphitoma philberti - Greece

BAU-1888.1 Raphitoma philberti - Italy

BAU-2257.1 Raphitoma densa - Croatia

BAU-2269.2 Raphitoma petanii - Croatia

BAU-2273.1 Raphitoma petanii - Croatia

BAU-2269.1 Raphitoma petanii - Croatia

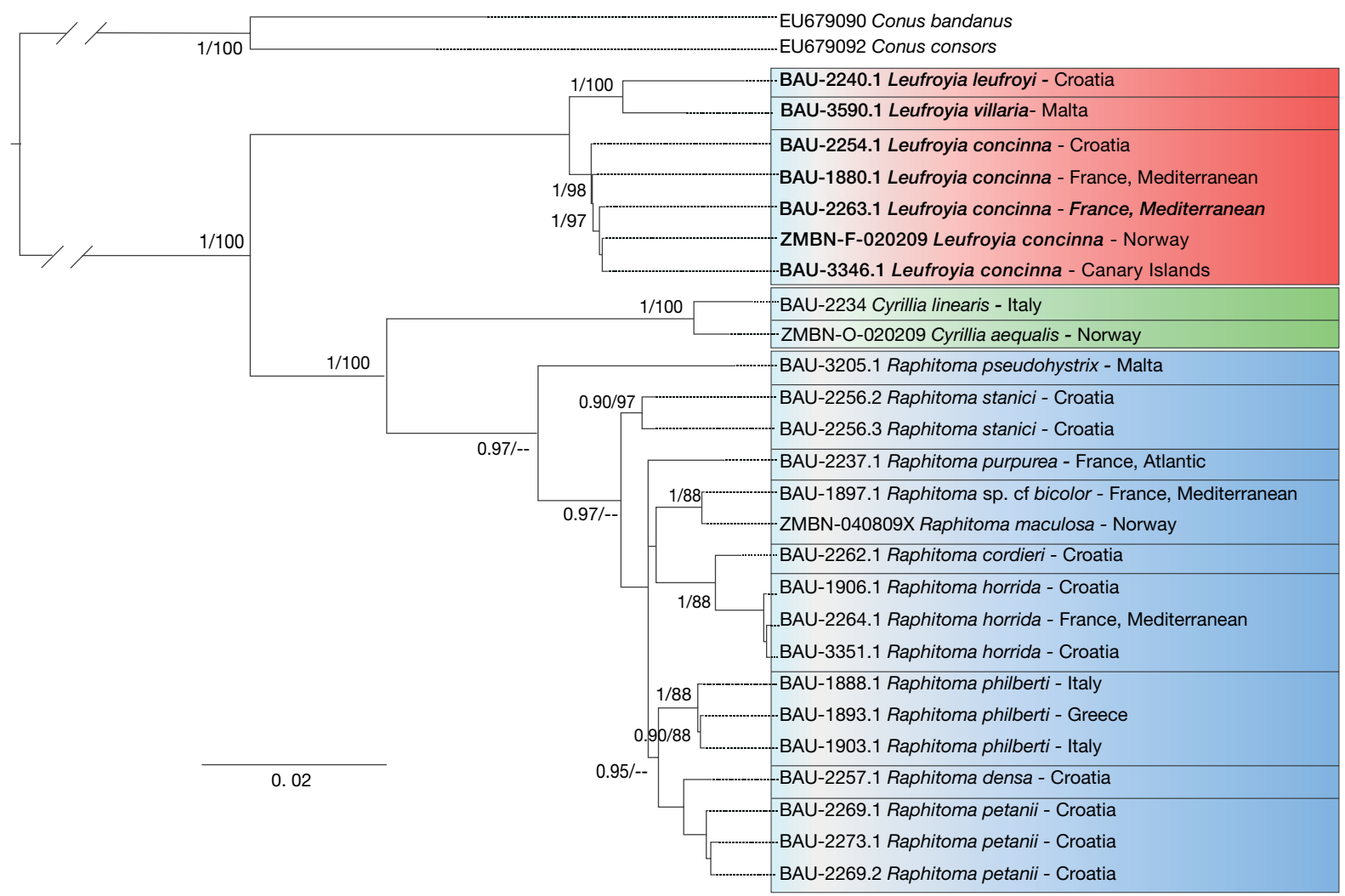

FIG. 3. - Phylogenetic relationships among species of Raphitomidae Bellardi, 1875. A, Bayesian analysis on the ITS2 alignment. B, Bayesian analysis on the combined (COI+ITS2) alignment. Numbers at nodes are posterior probabilities after a Bayesian analysis, and bootstrap supports after Maximum Likelihood analysis on 1000 pseudoreplicates; only values higher than $75 \%$ bootstrap support and 95\% posterior probability are reported. The boxes comprise the species hypotheses as defined by the ABGD analysis. 
L. villaria (Pusateri \& Giannuzzi-Savelli, 2008) with very high support. L. concinna was always supported as monophyletic, positioned as the sister to the pair L. leufroyi-L. villaria in the trees from the COI and the combined (COI+ITS2) datasets.

\section{SYSTEMATICS}

(Citation of unpublished names is not intended for taxonomic purposes).

Based on an extensive morphological study and largely supported by the genetic analyses, the systematics of the recent species of the genus Leufroyia is revised and four extant species are here recognised in the Northeastern Atlantic and the Mediterranean Sea: L. leufroyi (Michaud, 1828), L. concinna (Scacchi, 1836), L. erronea Monterosato, 1884, and L. villaria (Pusateri \& Giannuzzi-Savelli, 2008).

\section{Family RAPHITOMIDAE Bellardi, 1875}

\section{Genus Leufroyia Monterosato, 1884}

\section{Leufroyia Monterosato, 1884: 134.}

TYPe SPECIES. - Pleurotoma leufroyi Michaud, 1828, by subsequent designation (Crosse 1885).

ORIGINAL DESCRIPTION. — "Gruppo ben distinto ad anfratti rigonfi, costati, spiralmente striati; bocca ingrossata internamente, levigata, senza denti nè solchi” (Monterosato 1884: 134).

Diagnosis. - Shell of medium to large size for the family, from $16 \mathrm{~mm}$ (L. concinna) to $27 \mathrm{~mm}$ (L. erronea Monterosato, 1884) length, outline from suboval (L. erronea) to fusiform (L. leufroyi). Protoconch of 2.4-3.25 whorls when multispiral, with protoconch I (embryonic shell) of 0.9-1.15 whorls, with reticulate sculpture of spirals and orthocline axial threads, and protoconch II (larval shell) of 1.4-2.2 whorls, with diagonally cancellate sculpture, sometime with weakly keeled last whorl; when paucispiral (only fossils), protoconch II (larval shell) of 1.4-2.2 whorls, with reticulate sculpture of spirals and orthocline axial threads.

Teleoconch slender, of 7 (L. concinna) to 8 (L. leufroyi, L. villaria) uniformly convex whorls, wavy axial ribs much broader than thin and numerous spiral cords. Microsculpture of dense, rather conspicuous growth lines, and extremely fine and dense microgranules, less dense, scattered or absent (L. leufroyi) on 1-2 adapical whorls. Whole external surface covered with relatively thick (L. concinna, $L$. leufroyi) or thin and not persistent (L. erronea, L. villaria) periostracum.

Inner side of outer lip smooth with no denticles. Columella simple, slightly sinuous anteriorly.

Siphonal canal from short (L. erronea) to moderately long (L. leufroyi). Siphonal notch wide, plain.

REMARKS. - The protoconch is broader (c. 500-600 $\mu \mathrm{m}$ diameter) than in the 'multispiral' species of Raphitoma Bellardi, 1847 and Cyrillia Kobelt, 1905. Several Miocene and Pliocene species have a paucispiral protoconch: L. pseudoleufroyi (Marquet, 1998: 278), L. pseudoconcinna (Ceulemans, Van Dingenen \& Landau, 2018:113) and other still undescribed species (Landau et al.2020). Leufroyia differs from Raphitoma and Cyrillia also by the absence of denticles on the outer lip and by its much thinner and more numerous spiral cords.

DisTRIBUTION. - Stratigraphic distribution: the genus appears in the Middle Miocene with records from the Langhian of the Loire Basin (France) (Peyrot 1938; Glibert 1954). Then it is known from the Langhian-Serravallian of the Paratethys, with records from the Vienna Basin, Austria (Hörnes 1854), Poland (Bałuk 2003), Ukraine (Friedberg 1912), the Karaman Basin (Serravallian Proto-Mediterranean), Turkey (Landau et al. 2003). In the Late Miocene it has been revised in the Tortonian of the nothwestern France (Landau et al. 2020), and it is known from the Messinian of the Loire Basin (France) (Brébion 1964). Then, it is continuously present throughout the Pliocene (e.g. Sacco 1904; Cipolla 1914), and the Pleistocene (e.g. Cerulli-Irelli 1910). Based on the current knowledge, the extant species of the genus are restricted to the North-East Atlantic, from the North Sea (Norway) south to Angola, and the Mediterranean Sea.

\section{Leufroyia leufroyi (Michaud, 1828)} (Figs 4-8)

Pleurotoma leufroyi Michaud, 1828: 121, pl. 1, figs 5, 6.

Pleurotoma zonalis Delle Chiaje, 1831: pl. 84, fig. 1.

Pleurotoma cyrilli O.G. Costa, 1844: 54.

Murex caudicula Nardo, 1847: 59 ex Chiereghini ms - Brusina 1870: 158.

Clathurella leufroyi var. albida Bucquoy, Dautzenberg \& Dollfus, 1883: 96.

Clathurella mirabilis Locard, 1891: 68.

Clathrurella [sic] concina [sic] - sensu Ostroumoff 1896: 59 non Scacchi, 1836.

Clathurella leufroyi - Bucquoy et al. 1883: 95, pl. 14, figs 3, 4 Carus 1893: 427, no. 16 - Claudon 1902: 189 - Kobelt 1905: 365, pl. 96, figs 4, 5 - Coen 1933: 74, no. 482 - Dautzenberg 1889: 28 G.O. Sars 1878: 361 - Gignoux 1913: 93 - J.T. Marshall 1912: 297 - Locard \& Caziot 1899: 62 - Locard 1886: 115; 1892: 68, fig. 54; 1899: 49 - Nobre 1936: 52, pl. 32, fig. 4; 1938: 133, pl. 19, fig. 8 - Norman 1899: 137 - Paulus \& Mars 1942: 76 - Sykes 1906: 186 - Tryon 1890: 276, pl. 18, fig. 33 - Watson 1886: 350.

Defrancia leufroyi - Appelius 1869: 138 - Caruana-Gatto \& Despott 1919: 25 - Cocconi 1873: 59 - Coppi 1869: 165 - Despott 1919: 181 - Foresti 1874: 71 - H. Adams \& A. Adams 1853: 96 - Jeffreys 1870: 82 - Monterosato 1872: 51 - Seguenza 1873: 298; 1875: 208 - Weinkauff 1868: 132 sp. 4; 1873: 11.

Homotoma leufroyi - Bellardi 1877: 274, no. 13.

Leufroyia leufroyi-Monterosato 1884: 134 - Di Stefano 1889: 101 - Pallary 1900: 257 - Bellini 1929: 31 - Montefameglio et al. 1979: 191 - Nordsieck \& Garcia Talavera 1979: 165, pl. 41, fig. 33 - Orlando \& Palazzi 1985: 44, no. 344 - Öztürk, Buzzurro \& Benli 2004: 59 - Brunetti \& Vecchi 2005: 3 - Brunetti \& Della Bella 2006: 118, 121 - Trono 2006: 65 - Mazziotti et al. 2008: 78 Cecalupo et al. 2008: pl. 70, no. 19 - Vazzana 2010: 71; 2011: 60.

Mangelia leufroyi - Forbes \& Hanley 1853: 468 pl. CXIII, figs 6, 7; pl. RR, fig. 1 - Malm 1855: 41 - Jeffreys 1856: 187; 1859: 199 G. B. Sowerby II 1859: pl. 19, fig. 11 - Capellini 1860: 48 - Doderlein 1864: 102 - P. Fischer 1878: 189, no. 500 - Scalia 1900: 25; 1907: 37 - Zelinskaya et al. 1968: 224, pl. 50, figs 40, 41.

Mangilia (Clathurella) leufroyi-Cossmann 1896: 124.

Mangilia (Leufroyia) leufroyi-Dollfus \& Dautzenberg 1886: 102.

Mangilia leufroyi - Friedberg 1912: pl. 14, fig. 8 - Meznerics 1933: 320 - Friedberg 1951: 222, pl. 14, fig. 8 . 


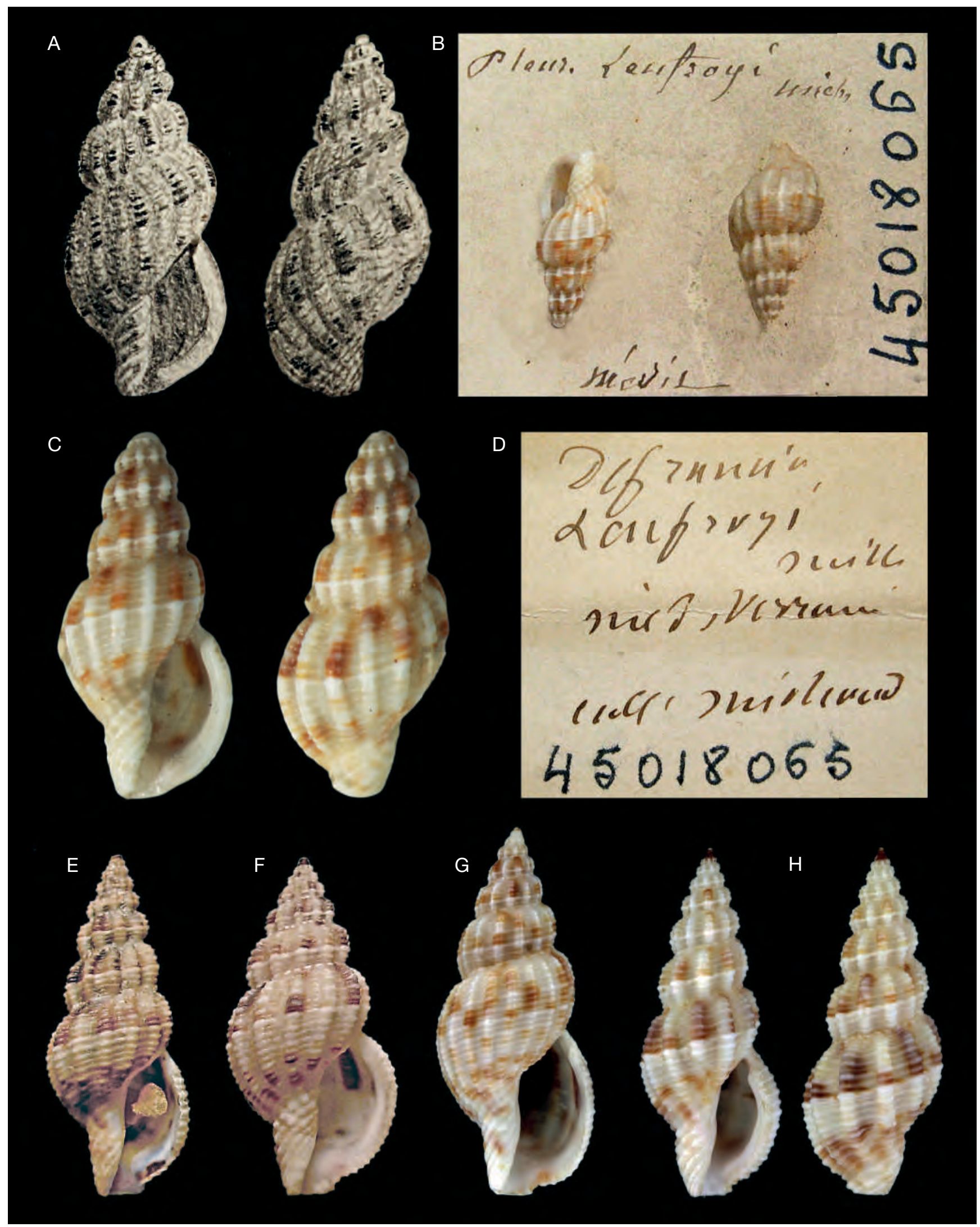

FIG. 4. - Leufroyia leufroyi (Michaud, 1828): A, original engravings; B, potential syntypes, MDCL ('Méditerranée') 13.1 and $15 \mathrm{~mm}$; C, potential syntype, $13.1 \mathrm{~mm}$; D, original label by Locard; E, Murter Island (Croatia), $15.4 \mathrm{~mm}(\mathrm{H} / \mathrm{D}=2.54)$; $\mathbf{F}$, Murter Island (Croatia), $15.2 \mathrm{~mm}(\mathrm{H} / \mathrm{D}=2.10)$; G, Gulf of Termini Imerese (Palermo - Italy), h. $22.71 \mathrm{~mm}$ (with 19 ribs); H, Isola delle Femmine (Palermo - Italy), h. $14 \mathrm{~mm}$ (specimen with 10 axial ribs on last whorl). Photo courtesy: B-D, Cédric Audibert; G-H, Ignazio Sparacio. 


1680
68060
0890




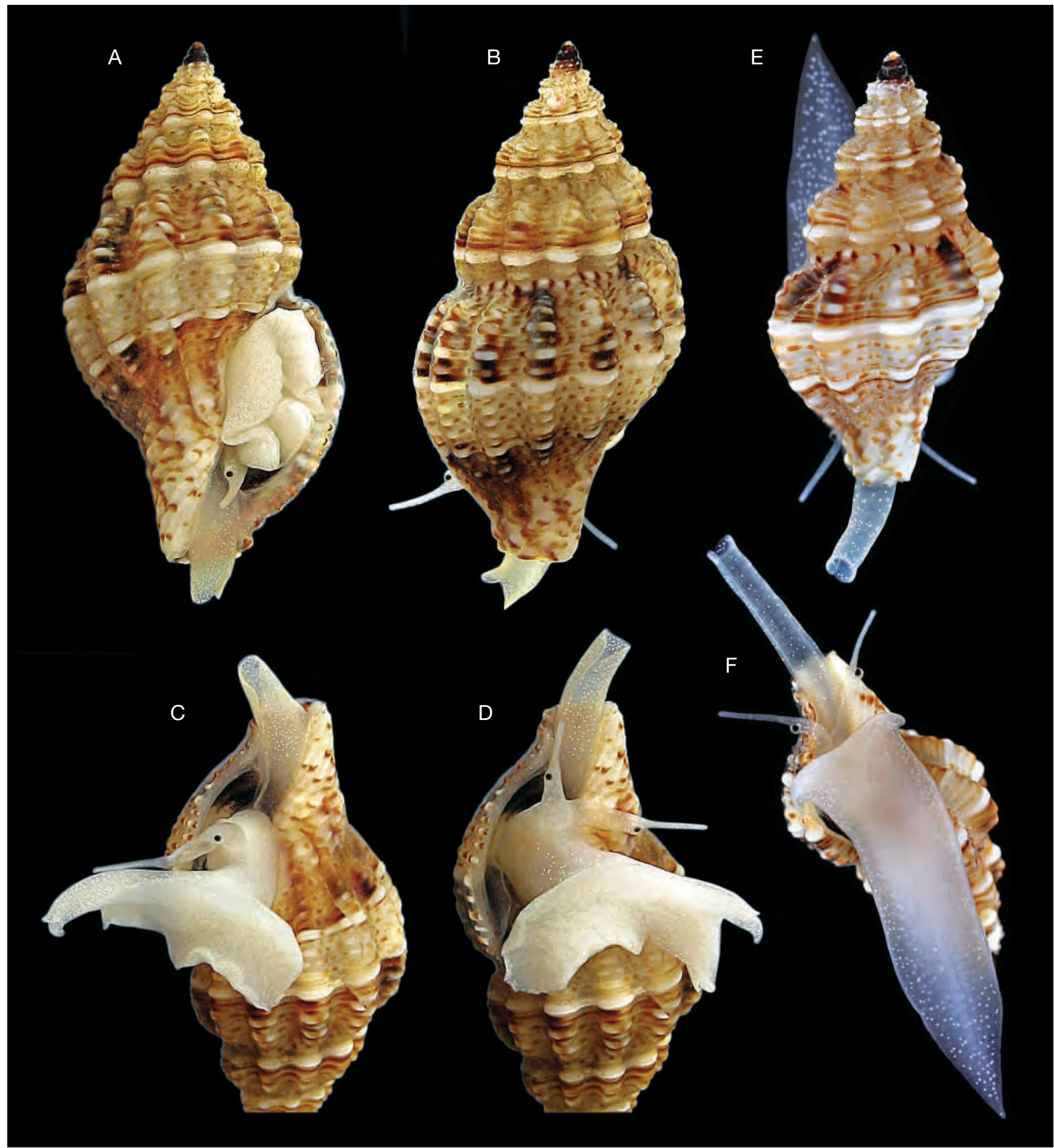

FIG. 6. - Photographs of two living animals of Leufroyia leufroyi (Michaud, 1828). A-D, Split, Croatia, 3 m, h. 10 mm; E-F, Čiovo Island, Croatia, 5 m, h. 6 mm. Photo courtesy: E-F, Pero Ugarković.

Peratotoma (Leufroyia) leufroyi - Sacco 1904: 53, pl. 13, figs 52, 53 - Cerulli-Irelli 1910: 59 (251), pl. 5 (36), fig. 46 -Cipolla 1914: 70 (174), pl. 3 (14), Fig. 24A, B.

Peratotoma leufroyi-Bałuk 2003: 73, pl. 29, fig. 12.

Philbertia (Leufroya) leufroyi - Thiele 1929: 370 - Steuer 1939: 44 fig. 18 - Devidts 1959: 104 - Priolo 1967: 702.
Philbertia (Leufroyia) leufroyi f. praecedens - Glibert, 1954: 60, pl. 7 , fig. 8 .

Philbertia leufroyi - Odhner 1931: 21 - Mars 1956: 44 - PasteurHumbert 1962: 104, pl. 39, fig. 169 - Powell 1966: 16, fig. 155F - Cadée 1968: 115 - Thiriot-Quiévreux 1972: 558, pl. 4, figs A-F - McMillan 1973: 56 - Spada et al., 1973: 55. 
Pleurotoma (Clathurella) leufroyi - Watson 1897: 304, no. 249.

Pleurotoma inflata - sensu Philippi 1836: 197, pl. XI, fig. 24 non De Cristofori \& Jan, 1832.

Pleurotoma lefroyi [sic] - Deshayes 1835: 275 - Forbes 1844: 157 - Aradas \& Benoit 1876: 251, no. 665.

Pleurotoma leufroyi - Potiez \& Michaud 1838: 445 - Kiener 1839: 70, pl. 24, fig. 3 - Reeve 1843: pl. 16, sp. 131 - Philippi 1844:165, pl. 11, fig. 24 - Requien 1848: 73, no. 522 - D’Orbigny 1852: 172 - Petit de la Saussaye 1852: 187; 1869: 153 - Hörnes 1854: 373 , pl. 40, Fig. 16A-C - Danilo \& Sandri 1856: 137, no. 140s Tallack 1861: 314 - Brusina 1866: 64 - Caruana 1867: 49 - Klećak 1873: 36 - Monterosato 1874: 277; 1875: 44, no. 744; 1878: 46; 1880: 230 - Nyst 1878:50 (1); 1881: pl. 3, Fig. 14A, B - Dewalque 1880: 478 - Locard 1891b: 11 Tesch 1912: 90 - Nobre 1931: 79, pl. 32, fig. 4.

Raphitoma (Leufroyia) leufroyi - Wenz 1943: 1453, fig. 4114 - Shikama \& Horikoshi 1963: 123, pl. 101, fig. 5 - Brébion 1964: 611, pl. 15, fig. 5 - Nordsieck 1968: 179, pl. 30, fig. 94.70; 1977: 60, pl. 20, fig. 157 - De Casa \& Hallgass 1979: 6 pl. 1 - Montefameglio et al. 1979: 191 - Piani 1980: 156 - Templado \& Llanso 1981: 36 - Van Aartsen et al. 1984: 45, fig. 219 - Sabelli et al. 1990: 44, 216 - Cavallo \& Repetto 1992: 26, 146, fig. 404 (WI) - Cossignani et al. 1992: 26, fig. 179 - Mifsud 1993: 6 -Vera-Peláez et al. 1999: 13.

Raphitoma concinna - Manousis 2012: 178 [top and low figures], non Scacchi, 1836.

Raphitoma erronea - Arduino et al. 1995: 94 (figured) non Monterosato, 1884.

Raphitoma leufroyi - Bellardi 1847: 89 - Sismonda 1847: 36 Ruggieri 1967: 314 - Albergoni \& Spada 1969: 158, 161 - Parenzan 1970: 210, pl. 45, fig. 853 - Spada 1971: 131 - Ghisotti 1972: 85 - Lozet J.-B. \& Dejean-Arrecgros 1977:112, fig. 163 - D’Angelo \& Gargiullo 1978: 153 (figured) - Biagi \& Corselli 1978: 11 Bogi, Coppini \& Margelli 1980: 14, fig. 2 - Terreni 1981: 41, no. 336 - Corselli, 1981: 16 - Berardelli et al. 1982:330 - Idato, Fresi \& Russo 1983: 112 - Poppe \& Goto 1991: 44,167, pl. 35, fig. 22, pl. 1, fig. 25 - Barash \& Danin 1992: 161, fig. $184-$ Cachia, Mifsud \& Sammut 1993: 34 - Delamotte \& VardalaTheodorou 1994: 137, fig. 7 - Arduino et al. 1995: 94 (figured) - Hayward, Wigham \& Yonow 1995: 536, fig. 10.17 - Giribet \& Peñas 1997: 53 - Oliverio 1997: 86 - Bogi \& Cauli 1998: 134 - Cachia 1999: 90 - Olabarria, Urgorri \& Troncoso 1999: 89 - Avila et al. 2000: 154 - Borja \& Muxika 2001: 76 - Cachia, Mifsud \& Sammut 2001: 67, pl. 10, fig. 5; 2004: 254 - Martini et al. 2001: 193 - Landau et al. 2003: 271, pls. 45, fig. 8 - Rolán 2005: 172, fig. 789 - Repetto et al. 2005: 39, 218, fig. 900 - Peñas et al. 2006: 43 - Oliver Baldoví 2007: 39 - Vardala-Theodorou \& Nicolaidou 2007: 65 - Soppelsa et al. 2007: 27 - Cecalupo et al. 2008: 32 - Pusateri \& Giannuzzi-Savelli 2008: 124, figs 5, 7, 9, 14 - Robin 2008: 454, fig. 16 - Scaperrotta et al. 2010: 96 (figured) - Cossignani \& Ardovini 2011: 31, 326 (figured) Gofas, Moreno \& Salas 2011: 339 (figured) - Rolán 2011: 230, fig. 76L, M - Manousis 2012: 179 [only upper figure, lower one is L. concinna] - Oliver et al. 2012: 55; 2015: 109 - Trono \& Macrì 2013: 35 - Ceulemans et al. 2018: 113 - Manousis et al. 2018: 21, fig. 14A-C - Trigo et al. 2018: 355 - Muñoz Ferrera de Castro et al. 2019: 162-163 (figured).

Type Material. - Pleurotoma leufroyi Michaud: Potential syntypes. Mediterranean Sea 2 sh; Lyon Museum 45018065; Mediterranean; 13.1 and $15 \mathrm{~mm}$ long, glued with the apex pointing downward, on a cardboard labelled by Michaud ("PleuR. leufroyi Mich./Médit.") and by Locard ("Defrancia Leufroyi Mich/méditerranée/coll. Michaud") (Boyer \& D’Audibert 2007: 151).
Pleurotoma zonalis Delle Chiaje: not found, it should be searched in the general collection at Museo Zoologico di Napoli, currently not revised (Sergio Duraccio pers. comm.).

Pleurotoma cyrilli O.G. Costa: not found, it should be searched in the general collection at Museo Zoologico di Napoli, currently not revised (Sergio Duraccio pers. comm.).

Murex caudicula Nardo: not available; it should be in the Stefano Chiereghini collections (Museo di Storia Naturale, Torino), currently not accessible (Paolo Russo pers. comm.).

Clathurella mirabilis Locard, 1891 :

Syntype. France • 1 sh; MNHN-IM-2000-3104; Belle Isle; 18.6 mm.

TYPe LOCALITY. - Pleurotoma leufroyi Michaud: Mediterranean, "Habite la Méditerranée, côte d'Agde (Hérault)" [Lives in the Mediterranean, coast of Agde (Hérault): Michaud 1828].

Pleurotoma zonalis Delle Chiaje: Napoli.

Pleurotoma cyrilli O.G. Costa: Taranto.

Murex caudicula Nardo: Venezia.

Clathurella leufroyi var. albida Bucquoy, Dautzenberg \& Dollfus: côtes de Barbarie.

Clathurella mirabilis Locard: l'Océan.

Material eXamined. - NE Atlantic. Portugal - 1 sh; Algarve, Marinha Portimão; 16-18 m; coll. PUS.

Canary Islands • 1 sh; Gran Canaria, La Luz; 109 m; coll. PUS. Açores $1 \mathrm{sh}$; São Miguel Island, Ponta Delgada; coll. DSC.

Mediterranean. Spain • 2 sh; Alboran Sea; coll. OLI 1 sh; Cabo de Gata, coll. CRO • 1 sh; Malaga; coll. TRI • 1 sh; La Herradura; $10 \mathrm{~m}$; coll. AGA • 3 sh; Baleares; unprecised locality; SMNH 73167 - 2 sh; Formentera I., El Calo; leg. Alf Josefson; SMNH 73166D. France $\bullet 2$ sh; Antibes; coll. HOA $\bullet 6$ sh; Provence; HUJ coll. Coen 8092B - $1 \mathrm{sh}$; St. Raphael; labelled by Monts. "leufroyi var. parva"; MCZR-M-17111 1 sh; St. Raphael; coll. HOA • 2 sh; St. Raphael, Le Dramont; coll. HOA 1 sh; Cassis; MNHN coll. Locard.

Corsica $\bullet 8$ sh; Baie de Calvi; legit A. Warén, SMNH 73171L - 1 sh; Ile Rouge; 40 m; coll. BAR 11 sh; Alistro; coll. MAR $\bullet 1$ sh; Ajaccio; coll. CRO • 4 lv; Corsica2019; Cap Corse; MNHNIM-2019-4036, MNHN-IM-2019-4093, MNHN-IM-2019-5302, MNHN-IM-2019-5315.

Sardinia $\bullet 3$ sh; no. 8092A; no precise locality; HUJ coll. Coen $\bullet 3$ sh; no precise locality; MCZR-M-17111 2 sh; S. Teresa di Gallura; 6 m; coll. CRO • $1 \mathrm{sh}$; Olbia; coll. CRO $1 \mathrm{sh}$; Porto Conte; coll. OLI - 2 sh; Porto Conte, Nettuno cave; 15 m; coll. OLI • 14 sh; Poetto; coll. PIS • 1 lv; Villasimius; 3907’43”'N, 9³2'17”E; BAU-1742. Sicily 1 sh; Porticello; coll. GIR $\bullet 1$ sh; Ustica I., Punta Gavazzi; $50 \mathrm{~m}$; coll. AGA $-3 \mathrm{sh}$; Palermo; sub nomine leufroyi var. minor; MCZR-M-17111 • 3 sh; Palermo; sub nomine "Leufroyia malatina" Monts. ms; MCZR-M-17111 • 2 sh; Palermo; "var. albescens"Monts; MCZR-M-17111 • 1 h; Palermo Gulf; coll. GIR • 8 sh; Palermo Gulf; coll. PUS $\bullet 4$ sh; Isola delle Femmine; coll. PUS $\bullet 5$ sh; Isola delle Femmine; coll. SER $\bullet 2$ sh; Isola delle Femmine; coll. GIR - 2 sh; Isola delle Femmine; coll. CRO • 1 sh; Trapani; coll. OCC - 2 sh; Favignana I.; coll. PUS $\bullet 1$ sh; Sicily Channel; coll. TRI - 1 h; Lampedusa I., Punta Cappellone; 45 m; coll. CRO • 1 sh; SE Sicily; coll. ARD • 1 sh; unprecised locality; MRSNT no. 45335 - 2 sh; Punta Braccetto; coll. OCC $\bullet 3$ sh; Porto Palo di Siracusa - 1 sh; coll. GER • Brucoli; coll. CRO • 2 sh; Isola delle Correnti; $15 \mathrm{~m}$; coll. PIE $\bullet 4$ sh; Cannizzaro; $45 \mathrm{~m}$; coll. GER $\bullet 3$ sh; Cannizzaro; $45 \mathrm{~m}$; coll. CRO $\bullet 2$ sh; Catania, Acireale; $15 \mathrm{~m}$; coll. PAG - 18 sh; Acitrezza; coll. GER $\bullet 4$ sh; Acitrezza; coll. CRO • 1 sh; Acitrezza; coll. PAG.

Italy • 1 sh; Gallinara I.; $40 \mathrm{~m}$; coll. REP $\bullet 5$ sh; Bergeggi; 38 m; coll. REP • 1 sh; Capo Noli; 2 m; coll. REP 1 sh; Camogli, S. Fruttuoso; $42 \mathrm{~m}$; coll. REP $\bullet 1$ sh; Sestri Levante, Riva Trigoso; 20 m; coll. REP • 6 sh; Gorgona I.; $80 \mathrm{~m}$; coll. BAL $\bullet 1$ sh; Capraia I.; $80 \mathrm{~m}$; coll. MAR • $8 \mathrm{sh}$; Capraia I.; $40 \mathrm{~m}$; coll. PAO • $1 \mathrm{sh}$; Elba I.; coll. MAR • 1 sh; Elba I.; coll. GOR 1 sh; Elba I.; coll. BAR • 1 sh; Elba I., Buccale; coll. PAG • 1 sh; Elba I., Manaregno; coll. TRI • 6 sh; Grosseto, Punta Ala; 5 m; coll. REP • 1 sh; Grosseto; coll. OCC • 5 sh; 


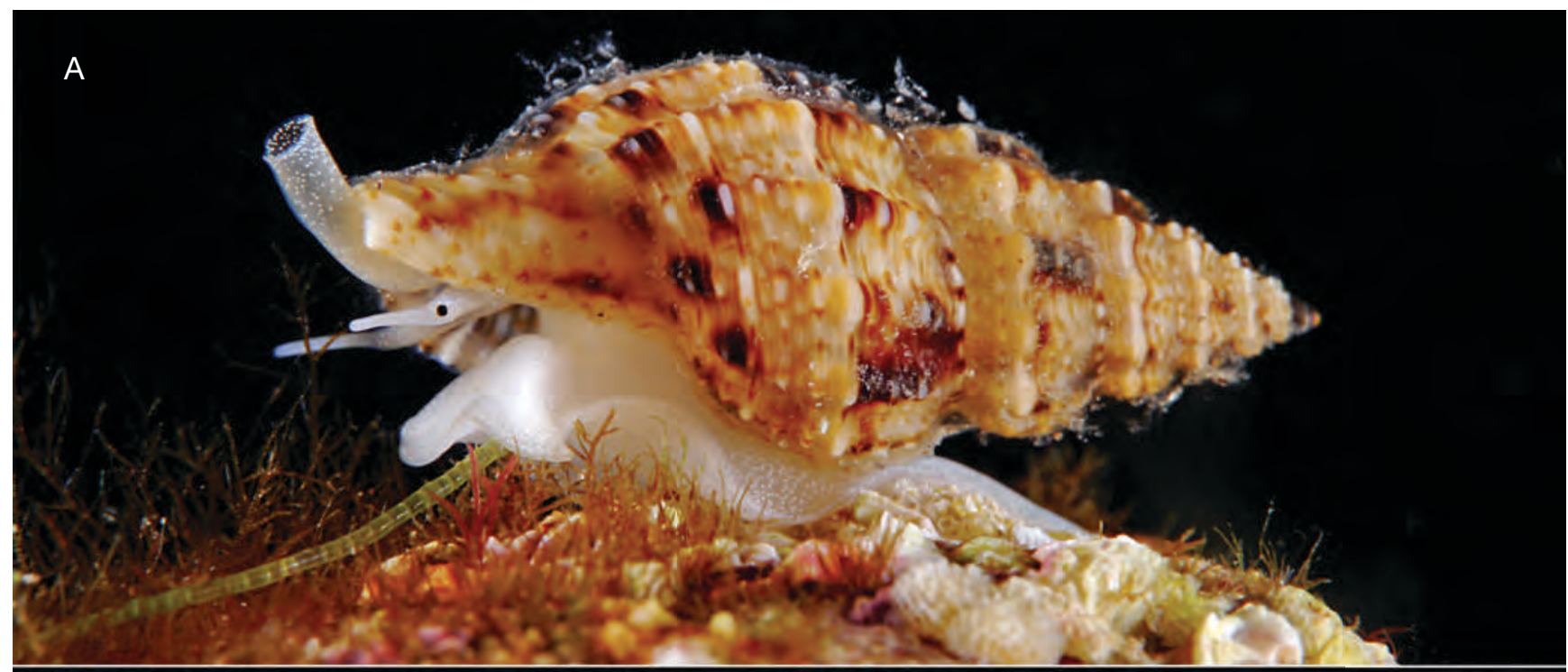

B

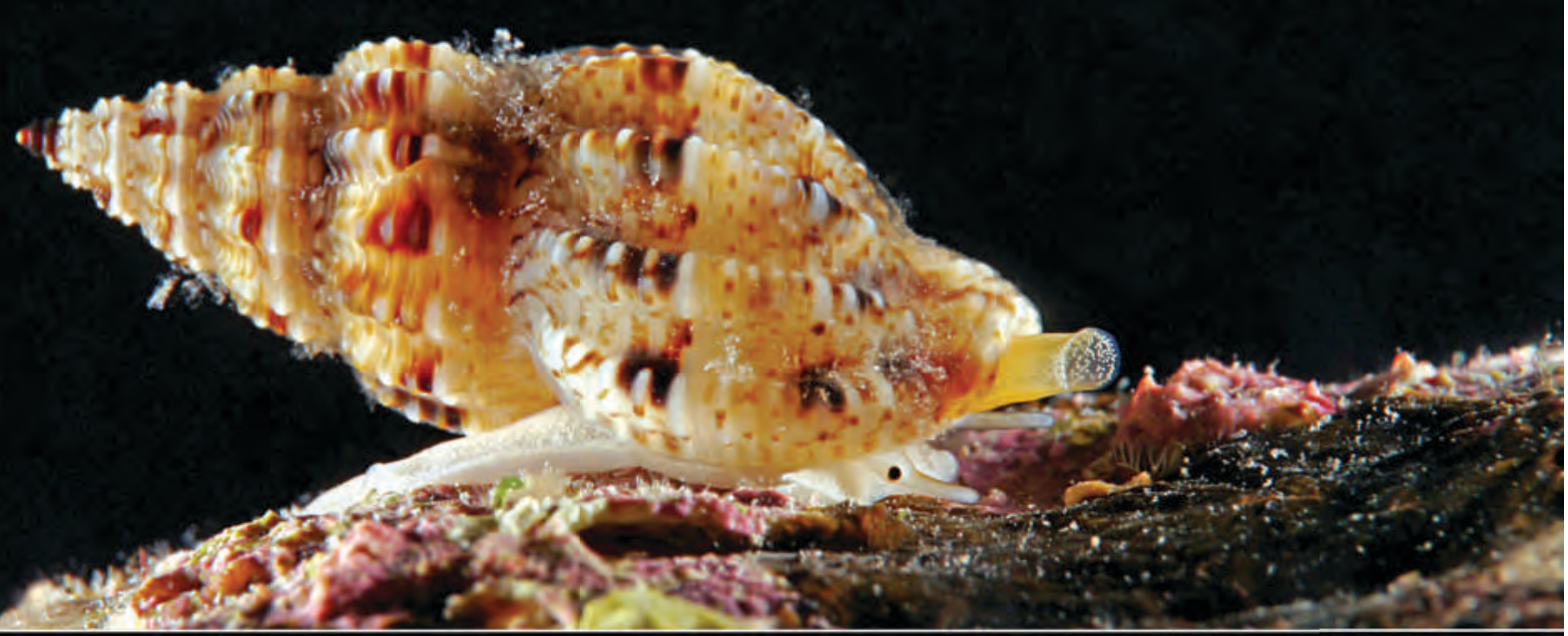

C

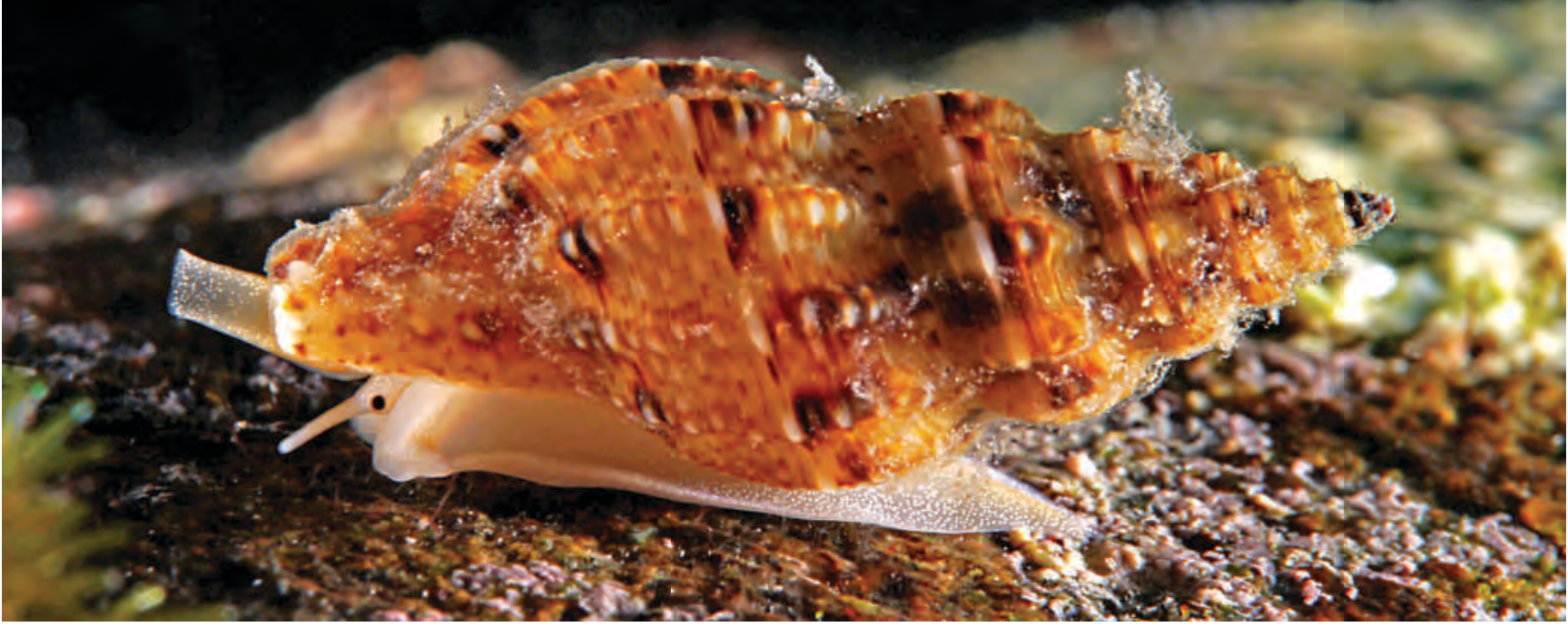

FIG. 7. - Underwater photographs of three living animals of Leufroyia leufroyi (Michaud, 1828). A-C, France, Cap d'Antibes, 13-17 m. Photo courtesy: Dominique Horst. 
Porto Santo Stefano; coll. PAG $\bullet 7$ sh; Gulf of Baratti; 5 m; coll. PAO - 7 sh; Gulf of Baratti; 5 m; coll. BAL $\bullet 1$ sh; Livorno, Bagni Fiume; coll. PAG $\bullet 1$ sh; Livorno, Bagni Fiume; coll. MAR $\bullet 1$ sh; Livorno, Bagni Fiume; coll. PAG $\bullet 6$ sh; Castiglioncello; coll. MAR $\bullet 1$ sh; Vada; coll. PAG $\bullet 1$ sh; Ladispoli, Torre Flavia; MCZR; coll. Pizzini - 2 sh; Ostia; coll. PIE $\bullet 1$ sh; off Fiumicino; 30 m; coll. PAG $\bullet 7$ sh; Santa Marinella; 27 m; coll. AGA $\bullet 1$ sh; Zannone I.; coll. FUM - 1 sh; Ponza I., Secca dei mattoni; 26 m; coll. CRO • 23 sh; Procida I.; coll. CRO • 4 sh; Procida I., Punta Pioppeto; 6 m; coll. CRO - 3 sh; Napoli; var albolineata Monts ms.; MCZR-M • 1 sh; Sorrento, Marina di Puolo; coll. DUR • 3 sh; Capri I.; coll. CRO 1 sh; Cetraro; coll. RON $\bullet 3$ sh; Costa Viola; 38 m; coll. PAO $\bullet 4$ sh; Scilla; coll. GER $\bullet 7$ sh; Scilla; coll. VAZ $\bullet 1$ sh; Scilla; 50 m; coll. PAG - 14 sh; Scilla; 50 m; coll. CRO 1 sh; Scilla; 50 m; coll. TIS $\bullet 3$ sh; Lazzàro; coll. VAZ $\bullet 15 \mathrm{sh}$; Isola di Capo Rizzuto; 45-60 m; coll. MEL - 4 sh; Maratea; coll. CAR • 5 sh; Campomarino; coll. DIN • 1 sh; Porto Cesareo; coll. MAC • 1 sh; Lama; coll. NOT $\bullet 1$ sh; Novaglie; coll. MAC $\bullet 1$ sh; Marina di Ugento; coll. MAC $\bullet 1$ sh; Monopoli, Cala Corvino; coll. DUR $\bullet 2$ sh; Giovinazzo; coll. MEL $\bullet 2$ sh; San Nicola I.; coll. AGA $\bullet 1$ sh; Ortona; 8 m; coll. PAG.

Morocco $\bullet 2$ sh; Restinga; MRSNT no. 45337.

Malta 1 sh; no precise locality; coll. MIF.

Croatia • 2 sh; Korcula I.; 5 m; coll. AGA $\bullet 1$ sh; Dalmatia; coll. PUS - 2 sh; Zadar; SMNH 70482-70483 • 2 sh; Pag I., Košljun bay; 2-5 m; coll. PRK • 2 sh; Pag I., Ljubačka Vrata; 35 m; coll. UGA - 2 sh; Molat I.; amidst red coral colonies, 35-50 m; coll. PRK・ 10 sh; Sukošan; 2-7 m; coll. PRK • 25 sh; Dugi Otok I., Veli Garmenjak; 32-40 m; coll. PRK • 37 sh; Murter I., Kosirina bay; 1-7 m; coll. PRK - 2 sh; Žirje I.; amidst red coral colonies, 70-100 m; coll. PRK • 2 sh; Primošten, Šparadići; 2-6 m; coll. PRK • 1 sh; Sevid; 18 m; coll. UGA - 33 sh; Sevid; 2-8 m; coll. PRK • 6 sh; Jabuka I.; 15-35 m; coll. UGA - 5 sh; Jabuka I.; 15-35 m; coll. STA $\bullet 2$ sh; Čiovo I., Fumija; 10 m; coll. UGA • 2 sh; Šolta I.; 5-10 m; coll. STA $\bullet 23$ sh; Split; 1-5 m; coll. PRK • 1 sh; Vis I., Komiža; 35 m; coll. UGA • 1 sh; Brač I., Milna; 10-18 m; coll. PRK 13 sh; Brač I., Milna; 10-18 m; coll. STA - 2 sh; Brač I., Maslinova bay; 3-15 m; coll. PRK • 15 sh; Brač I., Maslinova bay; 3-15 m; coll. STA $\bullet 3$ sh; Omišs, Balića Rat; 4-8 m; coll. PRK • 20 sh; Lastovo I.; amidst red coral colonies; 70-100 m; coll. PRK • 14 sh; Lastovo I.; amidst red coral colonies; 70-100 m; coll. STA • 1 sh; Palagruža I.; 28 m; coll. UGA • 2 sh; Pelješac, Žuljana; $1 \mathrm{~m}$; coll. STA • $2 \mathrm{sh}$; Pelješac, Prapratno; $2-6 \mathrm{~m}$; coll. PRK $\bullet 5$ sh; Mljet I., Pod Škoji; 1 -3 m; coll.PRK• 32 sh; Mljet I.; amidst red coral colonies, 70-100 m; coll. PRK $\bullet 1$ sh; Zadar; $6 \mathrm{~m}$; coll. PAG $\bullet 1 \mathrm{lv}$; Sevid; 4328'46”N, 1602’08”'E; 2-4 m; BAU-2240.1.

Greece $\bullet 1$ sh; Athens, Varkiza; coll. TRI $\bullet 1$ sh; Astypalea I.; coll. TRI - 1 sh; Antiparos I.; coll. BIN • 1 sh; Achaia; 5 m; coll. PAG $\bullet 1$ sh; Corfù I.; coll. BAR • 2 sh; Chalkidiki, Sani; coll. CRO • 1 sh; Crete Island, Mallia; coll. CRO.

Turkey 1 sh; Bozcaada I.; coll. PUS $\bullet 1$ sh; Adana, Yumurtalik, coll. CGS • 1 sh; Bodrum, Salih I.; 35 m; coll. CGS $\bullet 1$ sh; Bodrum; 80 m; coll. CGS $\bullet 1$ sh; Güllük Bay; 44 m; coll. OZT 1 sh; Marmara Sea, Silivri; 25 m; coll. OZT.

DisTribution. - Known with certainty from the Early Pliocene to Recent; records from the Middle Miocene (Langhian of the Loire Basin: Peyrot 1938, Glibert 1954; Langhian of the Paratethys: Hörnes 1854, Bałuk 2003, Friedberg 1912; Serravallian of Karaman Basin: Landau et al. 2003) and from the Late Miocene (Messinian of the Loire Basin: Brébion 1964) although morphologically broadly similar are probably not conspecific (B. Landau pers. comm.), and need to be reanalysed in the framework of a revision of the genus Leufroyia in the Miocene.

Early Pliocene: central Mediterranean, Italy (Sacco 1904). Early-late Pliocene: central Mediterranean, Italy (Cipolla 1914).

Early Pleistocene: central Mediterranean, Italy (Cerulli-Irelli 1910). [From Landau et al. 2003].

Recent: Northeastern Atlantic from the Atlantic coast of France (Belle Isle), south to Portugal, Açores, Madeira and Canary Islands. The entire Mediterranean and Marmara Sea (Ostroumoff 1896: 59). Leufroyia leufroyi is relatively common on rocky bottoms from a depth of $1 \mathrm{~m}$ to more than $100 \mathrm{~m}$, where it lives under stones or amidst algae, but also in sciaphylous habitats, including amidst red coral colonies where it is also quite frequent. It often lives in sympatry/syntopy with other raphitomids, also with other Leufroyia spp.; in shallow water it is frequently found with L. concinna even under the same stone or amidst the same alga, while sampling in sciaphilous habitats all 4 Leufroyia species can be found together.

ORIGINAL DESCRIPTION. - "P. Testa turrito-conica; luteo-fusca, longitudinaliter costata, striis transversis decussantibus exarata; apice obtusa [sic], anfractibus septenis; convexis, postremo duabus, fasciis spadiceis interruptis, superioribus una tantum, ornais; sutura excavata; apertura alba; labro incrassato; canali brevi, recto, extus eleganter plicato" (Michaud 1828:121).

\section{DESCRIPTION \\ Shell}

Robust and fusiform, of large size for the genus. Height: 10.83$22.93 \mathrm{~mm}$ (mean $15.26 \mathrm{~mm}, \mathrm{SD}: 3.07)$; width: 5.07-9.59 mm (mean $6.76 \mathrm{~mm}$, SD: 1.12); H/W: 2.0-2.62 (mean 2.27, SD: 0.13).

\section{Protoconch}

Multispiral with 2.6 to 3.0 (mean 2.84, SD: 0.14 ) convex whorls and small nucleus (d: $150 \mu \mathrm{m})$. Protoconch I of 0.9 whorls, diameter $242 \mu \mathrm{m}$, covered by dense cancellate sculpture; protoconch II with axial threads under suture and less dense and diagonally cancellate sculpture on rest of whorl. A keel at the end of last whorl of varying length. Protoconch-teleoconch boundary of flexuose, opisthocline growth lines. Colour always dark brown or blackish, with white or yellowish nucleus.

\section{Teleoconch}

Of 5.8-8.0 convex whorls (mean 6.87, SD: 0.58), with deep and distinct wavy sutures and prominent sculpture; suture area slightly thickened abapically and white coloured with brown dots or lines; whole external surface covered with relatively thick periostracum; dense and slightly pronounced growth lines present on ribs and interspaces, more pronounced on the subsutural ramp; surface glossy; microgranules absent on 1-2 adapical whorls, remaining ones covered with extremely fine and dense microgranulation.

Axial sculpture of 12-19 (mean 14.16, SD: 1.73) strong, equidistant, orthocline or slightly opisthocline ribs, broader than spiral cords, narrower than interspaces; ribs occasionally less elevated on body whorl of largest shells.

Spiral sculpture of 10-17 narrow cords (mean 13, SD: 1.75) above the aperture, of which 3-4 weak on subsutural ramp, remaining of almost equal strength and equally spaced, or with few additional thin cordlets between the strongest cords, rarely one thin cordlet between all pairs of strong cords; spiral interspaces 1.5-3 broader than cords; on first adapical whorl 2 or 3 strong spiral cords and one thin subsutural cordlet.

Siphonal fasciole with 6-11 (mean 8.21, SD: 1.11) strong and slightly nodulose cords, usually stronger than cords of body-whorl.

Cancellation rectangular, with very elongate and slightly elevated tubercles at the intersections. 


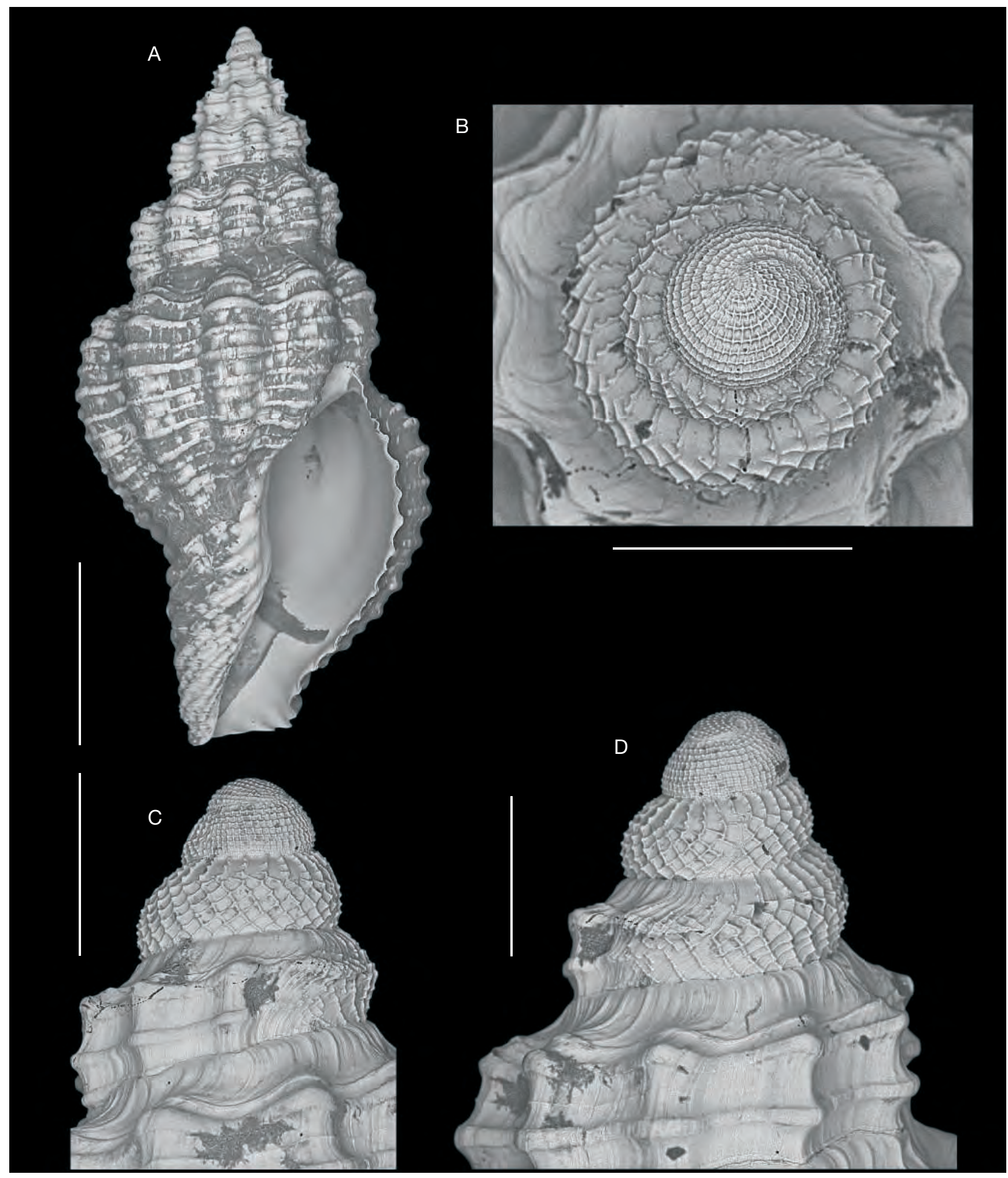

FIG. 8. - Leufroyia leufroyi (Michaud, 1828). Murter Island (Croatia), 3 m, h. 7.85 mm. A, Frontal view of shell; B-D, apical (B), frontal (D) and dorsal (C) view of protoconch. Scale bars: $2 \mathrm{~mm}(\mathrm{~A}), 300 \mu \mathrm{m}(\mathrm{B}-\mathrm{D})$.

Subsutural ramp narrow and more or less inclined, covered with dense growth marks of the anal sinus crossed by 3-4 weak spiral cordlets.
Columella simple, straight medially and arcuate or angled posteriorly. Siphonal canal wide and moderately long, posterior canal deep and moderately wide. 
Outer lip thickened and smooth internally, with edge crenated by spiral cords.

Height of aperture: 4.6-9.99 mm (mean $6.24 \mathrm{~mm}$, SD: 1.40); A/H: 36.98-45.97\% (mean 40.83\%, SD: 2.46).

\section{Coloration}

Background colour variable but usually light, from whitish to pale brownish; darker blotches, light brown to dark brown-blackish, variable in number (rarely absent), size and colour, irregularly placed on upper half of whorls and below periphery, usually on axial ribs, occasionally also in interspaces; a broad light spiral band almost devoid of blotches at aproximately $1 / 3$ to $1 / 2$ of whorl height. Occasionally a thin brown or reddish-brown cordlet above the median ligth band. Cords in light coloured areas often with many brownish dots and short lines, more evident in living specimens. Cords on siphonal fasciole light, whitish or yellowish, often with some light brown or pale orange narrow bands in the interspaces between low tubercles. Aperture internally white, often with light or dark brown blotches visible by transparency.

\section{Soft parts}

Foot very long, broad and deeply bilobed anteriorly and with recurved anterolateral corners, narrowly tapering posteriorly. Siphon cylindrical with ventral slit, widely opening anteriorly, very extensile. Head small with a pair of long cylindrical tentacles, black eyes on bulges about halfway their length, distal part slightly longer and much narrower than basal. Operculum absent, toxoglossate radula present.

Colour translucent white or cream, with minute white speckles densely covering upper side of foot, scattered or absent on sole, head and along neck. Tentacles translucent white or cream, with white speckles only along broadest part. Siphon translucent yellowish-white, pale ochre or pale orange, with dense white speckles (Figs 6, 7).

\section{REMARKS}

The collection Michaud was in part donated to the Musée de Lyon (now Musée des Confluences), in part passed to the city of Brive by Michaud's son Elysée, and in part bought by Locard (Locard, 1891b: 7). Only the Lyon material remains identifiable (Boyer \& D'Audibert 2007: 13; pl. 1, fig. 2), the part in Brive having been lost, and the part in Locard's collection having lost the original labels. The possible syntypes of Pleurotoma leufroyi Michaud remaining in Lyon Museum (lot no. 45018065) consist of 2 shells, with handwritten labels by Michaud and Locard. This is the same material referred to by Locard (1891b: 11). Michaud gave as size $20 \times 9 \mathrm{~mm}$, making the identification of the Lyon material as syntypical still not conclusive.

Leufroyia leufroyi was mistakenly confused by many authors with $L$. concinna. The first source seems to be that of Forbes $\&$ Hanley (1853: 468) who nonetheless pointed out that their English specimens of "leufroyi" (evidently L. concinna) were different from the Mediterranean ones (clearly typical L. leufroyi) by being broader, with more obsolete colouration and by having some spirals cords of brownish colour. Also Jeffreys
(1867: 366) recorded "leufroyi" from the British coast but his description seems to refer to a mix of characters of $L$. leufroyi and L. concinna. Other more recent misidentifications are e.g. in Fretter \& Graham (1985: 539) and Wigham \& Graham (2018: 137, fig. 161).

The maximum height of examined shells is $23 \mathrm{~mm}$, but specimens larger than $18 \mathrm{~mm}$ are rare. The height and maximum diameter of the protoconch depend on the number of whorls; in the specimen of Fig. 8 with 2.7 protoconch whorls the protoconch is $525 \mu \mathrm{m}$ high and $484 \mu \mathrm{m}$ wide. The diameters of nucleus and first whorl are small, similar to L. concinna, and smaller than in L. erronea and L. villaria. The colour of the protoconch is always dark brown or blackish, even in specimens with very light teleoconch. The sexes are separated but we did not find any evidence of bimodality in morphometrics, thus guessing no size dimorphism. Diagnostic features of L. leufroyi with all other extant Leufroyia spp. are the very dark protoconch and the dark brown blotches on a light background of the teleoconch (although shells tend to fade out after some years from collection). Some problematic specimens with small and very pale or even absent blotches on the teleoconch can be easily diagnosed by the dark protoconch (if retained). Some dark coloured shells of $L$. erronea may be misleading, but they can be easily identified by the lighter and broader protoconch, the teleoconch spiral sculpture, less slender outline and shorter siphonal canal.

According to Høisaeter $(2016: 28)$ L. leufroyi is not present along the European coasts North of Brittany (France) and all such records (like e.g. Lebour 1934: 553 from Plymouth, UK) should be in fact ascribed to L. concinna. As far as we know the northernmost confirmed record is Belle Isle (Bay of Biscay, Brittany, France) from the Locard coll. (MNHNIM-2000-3104) under the name Clathurella mirabilis, whereas the southern limit should be at Canary Islands.

The records of L. leufroyi from southern Angola (Rolán et al. 1998: 108) are based on L. villaria, according to the different pattern of the living animal (cream colour with small white spots, siphon clear orange, with many light coloured spots) and the slightly different protoconch. It is quite common in the whole Mediterranean, including Israel from where it was recorded by Barash \& Danin (1992) from various localities. Marquet (1998b) correctly separated the Pliocene North Sea Basin records as Raphitoma pseudoleufroyi (Marquet, 1998), a species with very similar teleoconch characters, but paucispiral protoconch ( $v$ s multispiral in L. leufroyi).

\section{Leufroyia concinna (Scacchi, 1836)}

(Figs 9-13)

Pleurotoma concinna Scacchi, 1836: 13, fig. 18.

Fusus boothi J. Smith, 1839: 98.

Defrancia leufroyi var. carnosula Jeffreys, 1867: 367.

Pleurotoma linearis var. major-violacea Monterosato, 1875: 270.

Homotoma michaudi Bellardi, 1877: 276. 
Raphitoma (Leufroyia) scacchii De Casa \& Hallgass, 1979: 6, pl. 1; non Bellardi, 1847.

Lineotoma concinna form maderensis Nordsieck \& Talavera, 1979: 166 , no. 34 .

Clathurella (Cirillia) linearis var. concinna - Coen 1933: 72, no. 480.

Clathurella (Cyrillia) linearis concinna - Kobelt 1905: 368, pl. 96, figs 6, 7 .

Clathurella concinna - Bucquoy et al., 1883: 98, pl. 14, fig. 5 - Tryon 1890: 277, pl. 34, fig. 85 - Locard 1886: 116; 1892: 69 - Locard \& Caziot 1899: 63.

Defrancia leufroyi - sensu Jeffreys, 1867: 366-368 non Michaud, 1828 - sensu Norman, 1879: 30, no. 237 non Michaud, 1828.

Leufroyia concinna - Monterosato 1884: 134 - Bellini 1929: 32 Trono 2006: 65 - Mazziotti et al. 2008: 78.

Peratotoma (Leufroyia) concinna - Cerulli-Irelli 1910: 60 (252), pl. 5 (36), fig. 47 - Cipolla 1914: 61 (175), pl. 3 (14), figs 25, 26.

Peratotoma michaudi - Tropeano et al. 1984: 55.

Philbertia concinna - Van Straaten 1960: 112.

Philbertia leufroyi boothi- E.H. Smith 1967: 176-187.

Philbertia leufroyi - sensu Hubendick \& Warén 1974: 28, fig. 222 non Michaud, 1828 - sensu Lebour 1934: 553 (veliger figured) non Michaud, 1828.

Pleurotoma (Defrancia) concinna - Monterosato 1877a: 43, pl. 5, fig. 1; 1877b: 336; 1877c: 425; 1878: 106; 1880: 230.

Pleurotoma (Leufroyia) michaudi-Sacco 1904: 53, pl. 13, figs 55, 56.

Pleurotoma concinna - Calcara 1839a: 5; 1839b: 17 - Philippi 1844: 166 - Petit de la Saussaye 1852: 133 - Weinkauff 1868: 133 [in the synonymy of Murex linearis Montagu, 1803]-Aradas \& Benoit 1876: 251 [in the synonymy of Murex linearis Montagu, 1803] - Carus 1893: 251 [in the synonymy of Murex linearis Montagu, 1803] - Cretella et al. 2005: 115, 121.

Pleurotoma concinnum [sic] - Sandri \& Danilo 1856: 137, no. 141 [in the synonymy of Murex linearis, Montagu, 1803].

Pleurotoma leufroyi - sensu Forbes \& Hanley 1853: 468-470 non Michaud, 1828.

Raphitoma (Cirillia) concinna-Nordsieck 1968: 178, pl. 30, fig. 94.62.

Raphitoma (Leufroyia) concinna-Nordsieck 1977: 60, pl. 20, fig. 159 - Piani 1980: 156 - Luque \& Templado 1981: 22 - Templado \& Llanso 1981: 36 - Sabelli et al. 1990: 44, 216.

Raphitoma concinna - Parenzan 1970: 210, pl. 44, fig. 851 - Ghisotti 1972: 85 - Bogi, Coppini \& Margelli 1980: 14, fig. 1 - Borja 1987: 217 - Poppe \& Goto 1991: 174, pl. 1, fig. 20 - Koutsoubas et al. 1992: 73 - Cachia, Mifsud \& Sammut 1993: 34 - Giribet \& Peńas 1994: 52; 1997: 52 - Panetta \& Imperatrice 1994: 39 Tabanelli \& Segurini 1994: 12 - Arduino et al. 1995: 94 (figured) Consolado Macedo 1996: 121, fig. 152 - Borja \& Muxika 2001: 76 - Cachia, Mifsud \& Sammut 2001: 64, pl. 9, fig. 10 - Basso \& Brusoni 2004: 40 - Öztürk, Buzzurro \& Benli 2004: 59 - Repetto et al. 2005: 39, 216, fig. 888 - Peñas et al. 2006: 43; 2009: 25 -Oliver Baldoví 2007: 39 - Vardala-Theodorou \& Nicolaidou 2007: 65 - Cecalupo et al. 2008: 32 - Cossignani \& Ardovini 2011: 31 , 324, 325 (figured) - Gofas, Moreno \& Salas 2011: 339 (figured) Manousis 2012: 178 (only central figure) - Oliver et al. 2012: 55;
2015: 109 - Trono \& Macrì 2013: 35 - Ceulemans et al. 2018: 113 - Manousis et al. 2018: 11, fig. 6a-c.

Raphitoma leufroyi - Fretter \& Graham 1985: 538-540, fig. 371 non Michaud, 1828 - Ardovini \& Cossignani 2004: 225 non Michaud, 1828 [only the first shell of 2nd row in the figure] - Manousis 2012: 179 (lower figure) non Michaud, 1828 - Wigham \& Graham 2018: 137, fig. 161 non Michaud, 1828.

Raphitoma michaudi - Chirli 1997: 84, pl. 24, figs 1-4.

Type Material. - Pleurotoma concinna Scacchi: presumably lost (Cretella et al. 2005). Fusus boothi J. Smith: presumably lost (Kathie Way pers. comm.). J. Smith's material was at the Anderson Museum (Glasgow) closed on 1887, thereafter moved at the Hunterian Museum (Glasgow) where this sample has not been found. Defrancia leufroyi var. carnosula Jeffreys: Types not found (Warén 1980: 33). Pleurotoma linearis var. major-violacea Monterosato: not found at the Museo Civico di Zoologia, Rome. Homotoma michaudi Bellardi: it should be at the Museo di Storia Naturale di Torino, currently not accessible. Raphitoma (Leufroyia) scacchii De Casa \& Hallgass: private collection Alessandro Hallgass (Rome). Lineotoma concinna form maderensis Nordsieck \& Talavera: SMF, Senckenberg Museum, Frankfurt/M (Germany) not seen.

Type LOCALITY. - Pleurotoma concinna Scacchi: "In sinu Neapolitano et Tarentino parum frequens" [scarcely frequent in the gulfs of Napoli and Taranto] (Scacchi 1836). Fusus boothi J. Smith: Oban and Skye (Scotland). Defrancia leufroyi var. carnosula Jeffreys: shetland. Pleurotoma linearis var. major-violacea Monterosato: Atlantic Ocean. Homotoma michaudi Bellardi: Pliocene of Zinola, Albenga and Vallone Torsero (Italy). Raphitoma (Leufroyia) scacchii De Casa \& Hallgass: Sardinia and La Maddalena Island. Lineotoma concinna form maderensis Nordsieck \& Talavera: Porto Santo (Madeira).

MATERIAL EXAMINED. - Atlantic. Norway • 1 lv; 60³3’N, 452'12”E; ZMBN-H-3-69・ $1 \mathrm{lv}$; $60^{\circ} 18^{\prime} \mathrm{N}, 5^{\circ} 10^{\prime} 48^{\prime \prime} \mathrm{E} ; \mathrm{ZMBN}-\mathrm{E}-23-67 \bullet 1 \mathrm{lv}$; $60^{\circ} 13^{\prime} 48^{\prime \prime} \mathrm{N}, 5^{\circ} 12^{\prime} \mathrm{E}$; ZMBN-020209-F.

Iceland $\bullet 1$ sh; Reykjavík; coll. KEL.

Great Britain • 1 sh; Clyde (Scotland); USNM $305163 \bullet 2$ sh; Aberdeen Bank; 57 $02^{\prime} \mathrm{N}, 01^{\circ} 12^{\prime} \mathrm{W} ; 58 \mathrm{~m}$, 27.VII.2011; coll. SWI • $1 \mathrm{sh}$; Cumbrae I.; Jeffreys coll. under "leufroyi"; USNM $190583 \bullet 3$ sh; North Sea, England; 53ำ'N, $2^{\circ} 10^{\prime}$ E; leg. S. Hanley; SMNH 70481 - 1 sh; Cornwall; leg. A. Gardiner in 1919; coll. FEN • 11 sh; Falmouth; 509'N, 54'W; leg. A. Gardiner in 1919; SMNH 70479 - 1 sh; Falmouth; $50^{\circ} 9^{\prime}$ N, $5^{\circ} 4^{\prime} W ;$ SMNH $70480 \bullet 1$ sh; Herm I.; Jeffreys coll. under "leufroyi"; USNM 190585 • 2 sh; Guernsey I.; Jeffreys coll. under "leufroyi"; USNM 190584.

France 1 sh; Roscoff; coll. DSC $\bullet 1$ sh; Ouessant I; coll. DSC. Spain • 1 sh; Gijòn; coll. GON • 1 sh; 10 km NNE Cap Finisterre; $42^{\circ} 55^{\prime} \mathrm{N}, 9^{\circ} 17^{\prime} \mathrm{W}$; SMHN 73165A • 1 sh; La Coruña; coll. GUB - 1 sh; El Ferrol; SMHN 73164A.

Portugal • 1 sh; Sesimbra; SMNH 24101 • 1 sh; Faro; SMNH 25009 - 1 sh; Sagres; SMNH 73211.

Canary Islands $\bullet 1$ sh; Lanzarote I., Puerto del Carmen; coll. DSC - 1 sh; Lanzarote I., Arrecife; coll. DSC.

Mediterranean.

Spain • 1 sh; Malaga; coll. PUS • 2 sh; Formentera I.; SMHN 70486A • 1 sh; Cadaqués; coll. PUS • 1 sh; Sitges; coll. PUS.

France $\bullet 1$ sh; Bouche du Rhone; coll. PUS • 2 sh; S. Raphael, Le Dramont; coll. HOA $\bullet 1$ sh; Antibes, Le Graillon; coll. HOA $\bullet 1$ sh; Antibes, Le Graillon; BAU-1880.1 • 2 sh; Provence; "C[oste] di Provenza”; MCZR-M 1 lv; Figuerolles, La Ciotat; 4309'53”N, 5०35'45"E; $15 \mathrm{~m}$; BAU-2263.1.

Corsica 1 sh; Baie de Calvi; 7 m; SMNH 73171J 1 sh; Ajaccio; coll. CRO • $1 \mathrm{lv}$; Corsica2019; Cap Corse; MNHN-IM-2019-4050. Sardinia $\bullet 1$ sh; Porto Conte; coll. OLI 11 sh; Isola Rossa; coll. DSC - 2 sh; S. Teresa di Gallura; 6 m; coll. CRO 1 sh; Cagliari; coll. PIS - 8 sh; Sant'Antioco; coll. PIS.

Sicily 1 sh; Palermo Gulf; coll. GIR $\bullet 6$ sh; Palermo; MCZR-M $17111 \bullet 1$ sh; Isola delle Femmine; coll. SER $\bullet 1$ sh; Marettimo I., 
A
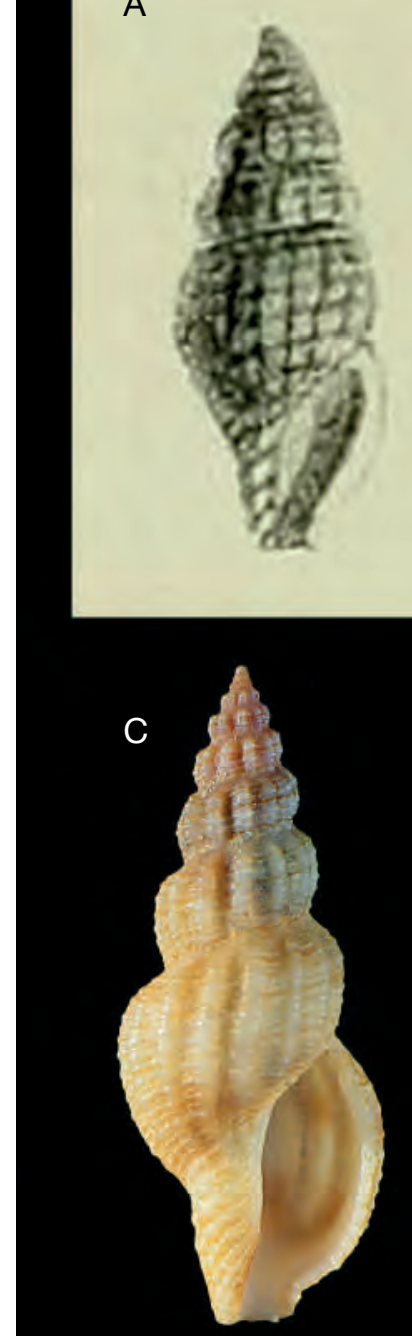
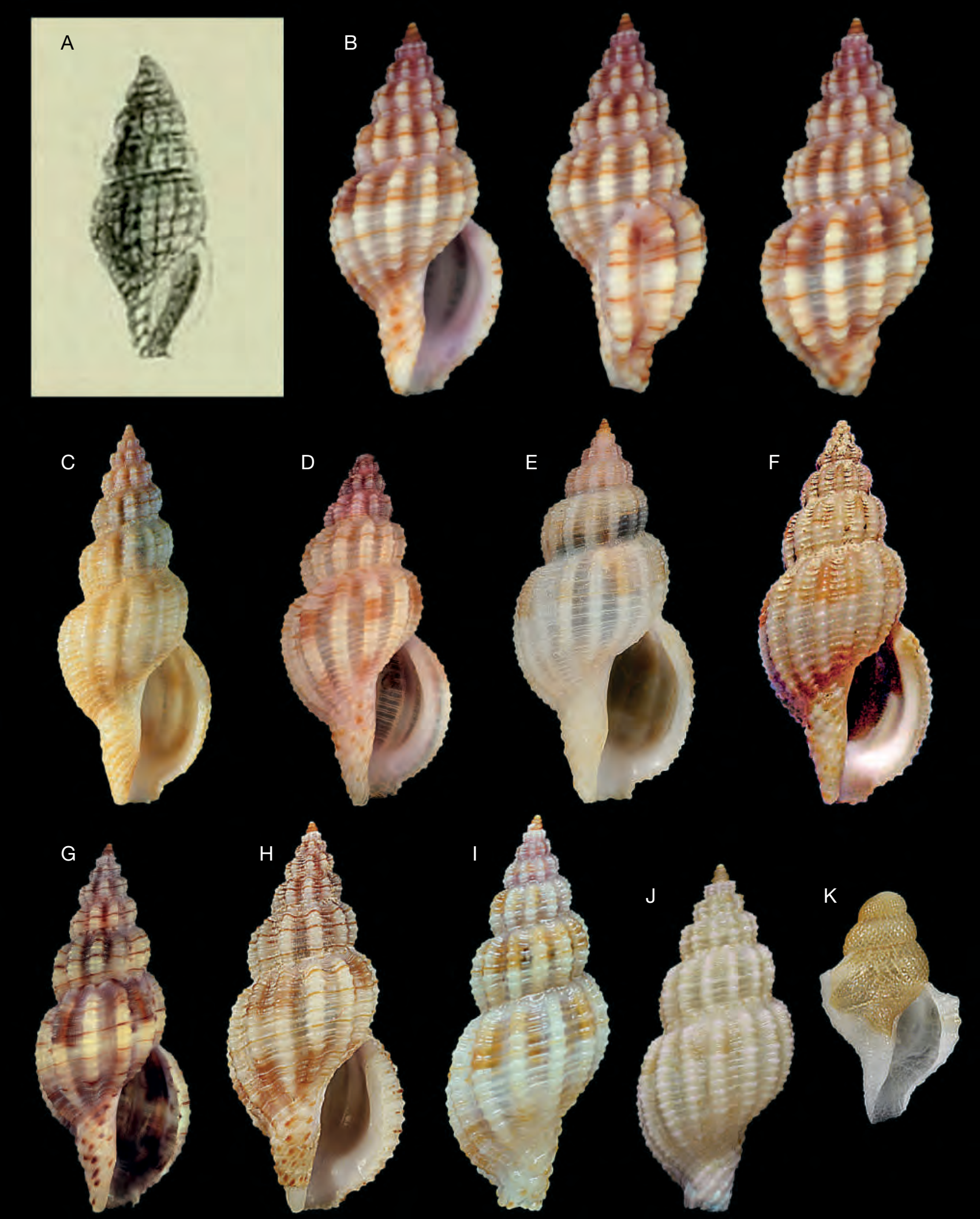

FIG. 9. - Leufroyia concinna (Scacchi, 1836) from Mediterranean Sea: A, original engraving; B, Korinthiakos Gulf (Greece) $60 \mathrm{~m}$, h. 9.8 mm; C, Göçek (Turkey), h. $14.1 \mathrm{~mm}$; D, Korinthiakos Gulf (Greece) 120 m, h. 10.7 mm; E, Capraia Island (Italy) 150 m, h. 15 mm; F, Mljet Island (Croatia) 60-100 m, h. 15.2 mm; G, Saronic Gulf (Greece) 30-70 m, h. 11.81 mm; H, Elba Island (Italy) 40 m, h. 14 mm; I, Le Dramont (Saint Raphael, France) 40 m, h. 14.7 mm; J, Le Dramont (Saint Raphael, France) 60 m, h. 10.8 mm; K, Elba Island (Italy), h. 1.1 mm. Photo courtesy: B, D, G, Costas Kontadakis; C, Bilal Oztürk; I, J, Dominique Horst. 
Revision of Mediterranean and NE Atlantic Raphitomidae 8: The genus Leufroyia Monterosato, 1884

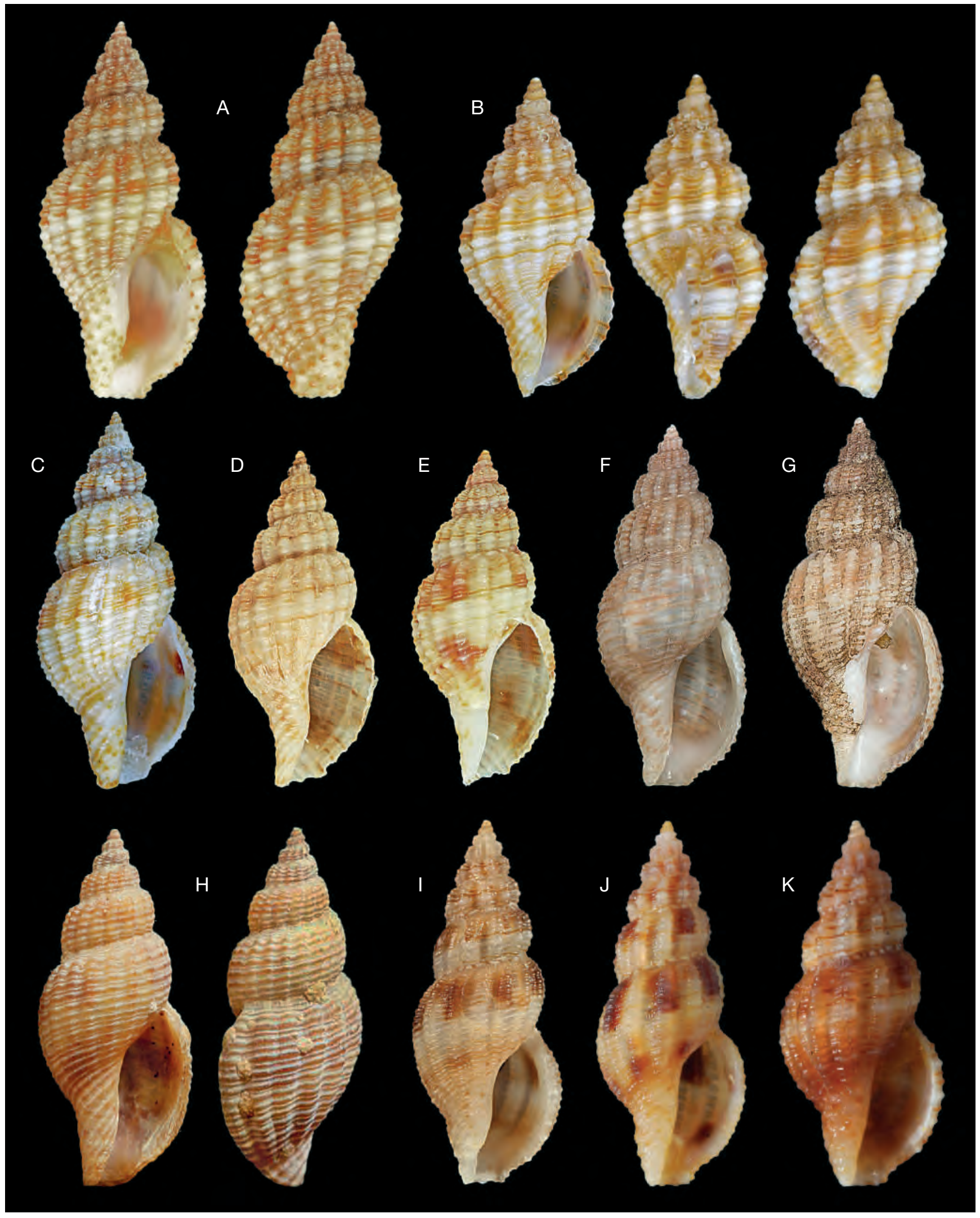

FIG. 10. - Leufroyia concinna (Scacchi, 1836) from NE Atlantic: A, Paimpol (Brittany, France), h. 13.6 mm; B, Ouessant Island (Finistère, France), h. 6.6 mm; C, Roscoff

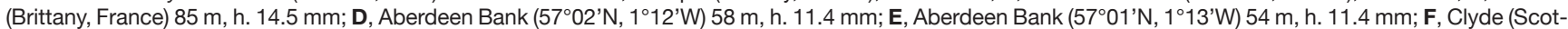
land), USNM 305163 ex Henderson coll., h. 12.9 mm; G, Cumbrae Island (Scotland) (USNM 190583 ex Jeffreys coll.), h. 13.3 mm with periostracum; H, Cornwall (England), h. 9.8 mm; I, Puerto del Carmen (Lanzarote Island - Canaries), h. 9.5 mm; J, Playa de Sardina (Gran Canaria Island), h. 8.5 mm; K, Playa de Sardina (Gran Canaria Island), h. 8.8 mm. Photo courtesy: A-E, Christian Delongueville; F-G, Jolanda Villacampa; H, David Fenwick; I, Ignazio Sparacio; J-K, Javier Martin.

ZOOSYSTEMA $\cdot 2020 \cdot 42(22)$

449 


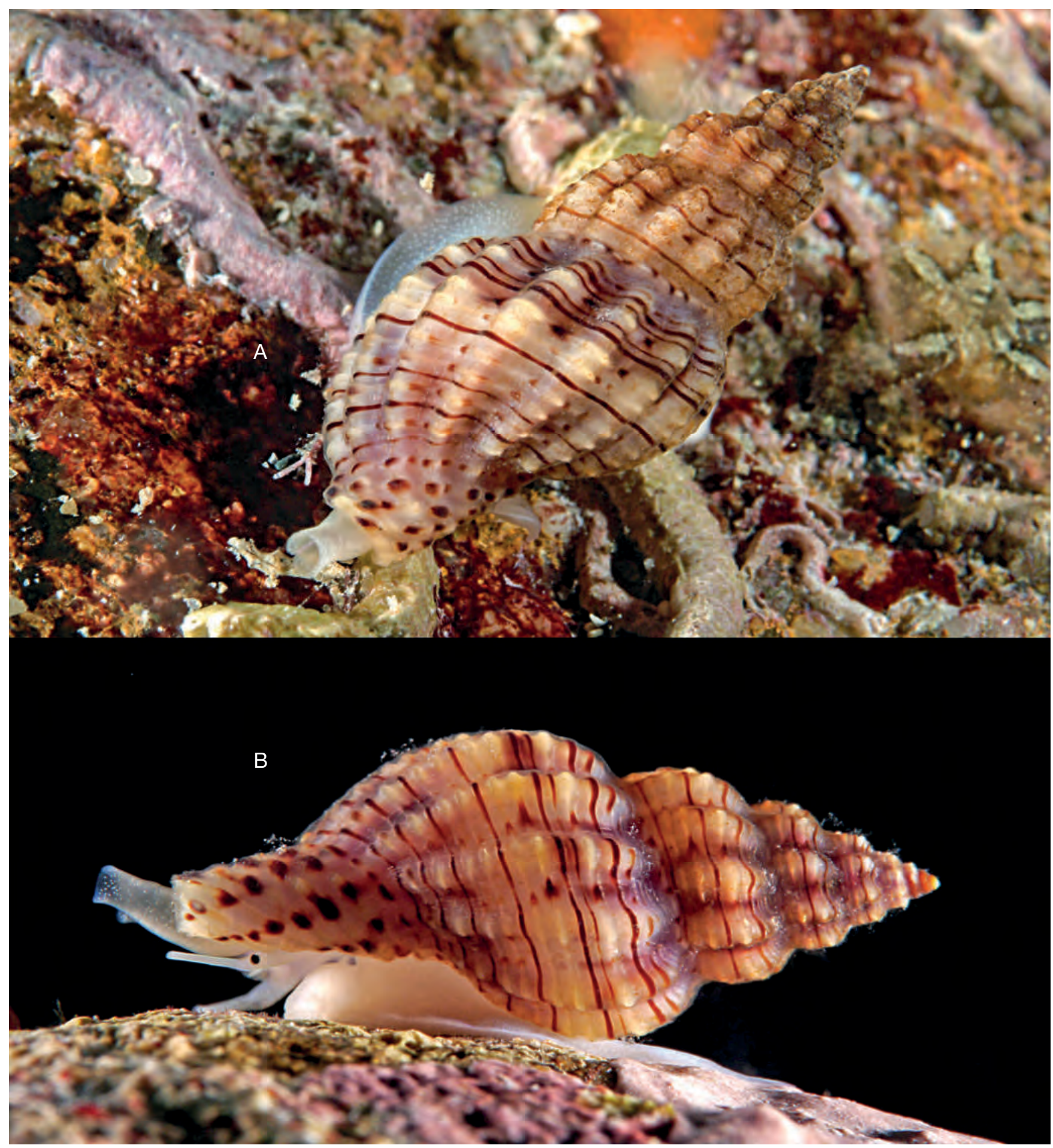

FIG. 11. - Underwater photographs of two living animals of Leufroyia concinna (Scacchi, 1836). A, Italy; B, France, Cap d'Antibes, 21 m. Photo courtesy: A, Alessandro Falleni; B, Dominique Horst.

Punta S. Simone; 40 m; coll. PAO 44 sh; Catania; MCZR-M 17342 - 1 sh; Ognina; coll. GER • 2 sh; Cannizzaro; coll. GER $\bullet 1$ sh; Acitrezza; coll. CRO • 1 sh; Acicastello; 38 m; coll. PAG • 1 sh; Messina; $6 \mathrm{~m}$; coll. PAG.

Tunisia 11 sh; Kerkennah Islands; NMR 2633.

Italy 5 sh; Bergeggi; $38 \mathrm{~m}$; coll. REP $\bullet 1$ sh; Capraia I.; coll. GOR - 1 sh; Elba I.; $40 \mathrm{~m}$; coll. BAR • 1 sh; Elba I., Punta dell'Acqua Bona; coll. GOR • 9 sh; Golfi di Baratti; $7 \mathrm{~m}$; coll. PAO • 3 sh; Formiche di Grosseto; coll. PAO • 2 sh; Porto Santo Stefano; coll. PAG $\bullet 6$ sh; Secca delle Vedove; 80-100 m; coll. PAO $\bullet 1$ sh; Castiglioncello; coll. MAR • $1 \mathrm{sh}$; Tor Paterno; coll. GER • 2 sh; Ostia; coll. PIE $\bullet 1$ sh; Circeo; coll. NAP・ 1 sh; Sorrento; coll. DUR - 1 sh; SMR; Giannutri I.; coll. • 1 sh; MCZR-M 16700; Napoli - 1 sh; Capri I.; sub nomine "Philbertia (Leufroyia) leufroyi albida BDD”; HUJ coll. Coen no. 8090; • 4 sh; Capri I.; coll. CRO • 5 sh; Maratea; coll. CAR $\bullet 1$ sh; Calabria, Costa Viola; 36 m; coll. PAO - 3 sh; Scilla; coll. CRO • 1 sh; Scilla; 50 m; coll. VAZ • 15 sh; Lazzaro; coll. VAZ $\bullet 1$ sh; Campomarino; coll. CRO $\bullet 1$ sh; Marina 

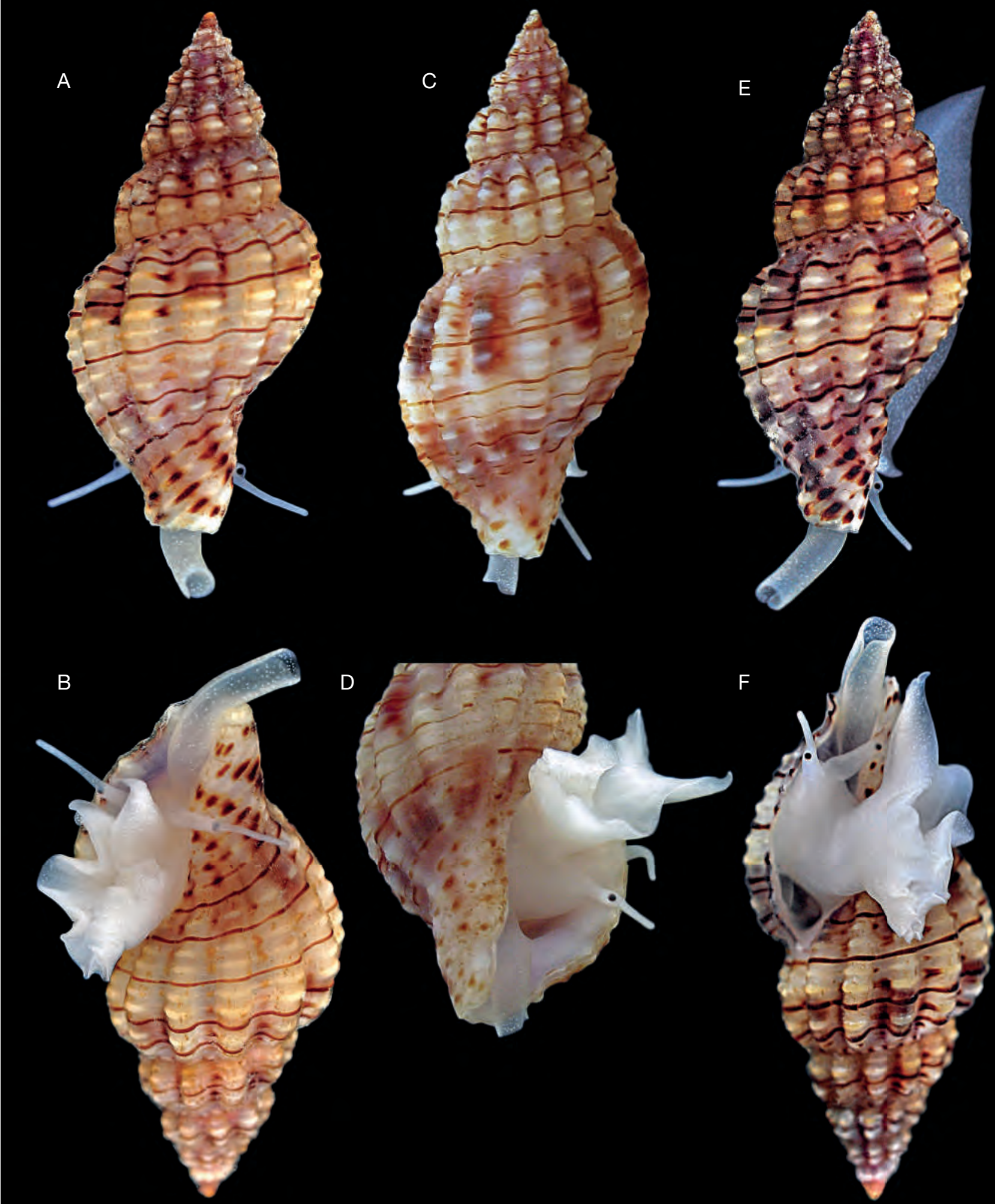

FIG. 12. - Photographs of three living animals of Leufroyia concinna (Scacchi, 1836): A-B, Čiovo Island (Croatia), 5 m, h. 9.5 mm; C-D, Pag Island (Croatia), 3 m; E-F, Čiovo Island (Croatia), 3 m, h. 11.5 mm. Photo courtesy: A-B, E-F, Pero Ugarković; C-D, Alen Petani.

di Ugento; coll. MAC $\bullet 2$ sh; S. Isidoro; coll. TRO $\bullet 1$ sh; Porto Badisco; coll. MAC $\bullet 2$ sh; Otranto.

Croatia; coll. MAC $\bullet 1$ sh; Dugi Otok I., Veli rat; as concinna var. grata ms; MCZR-M17342 • 5 sh; Pag I., Košljun bay; 2-5 m; coll. PRK
- $1 \mathrm{sh}$; Molat I.; amidst red coral colonies; 35-50 m; coll. PRK • 3 sh; Rivanj I.; 18-30 m; coll. PRK • 1 sh; Ugljan I., Karantun; 1-3 m; coll. PRK • 8 sh; Sukošan; 2-7 m; coll. PRK • 3 sh; Dugi Otok I., Mežanj; 10 m; coll. UGA 18 sh; Dugi Otok I., Veli Garmenjak; 


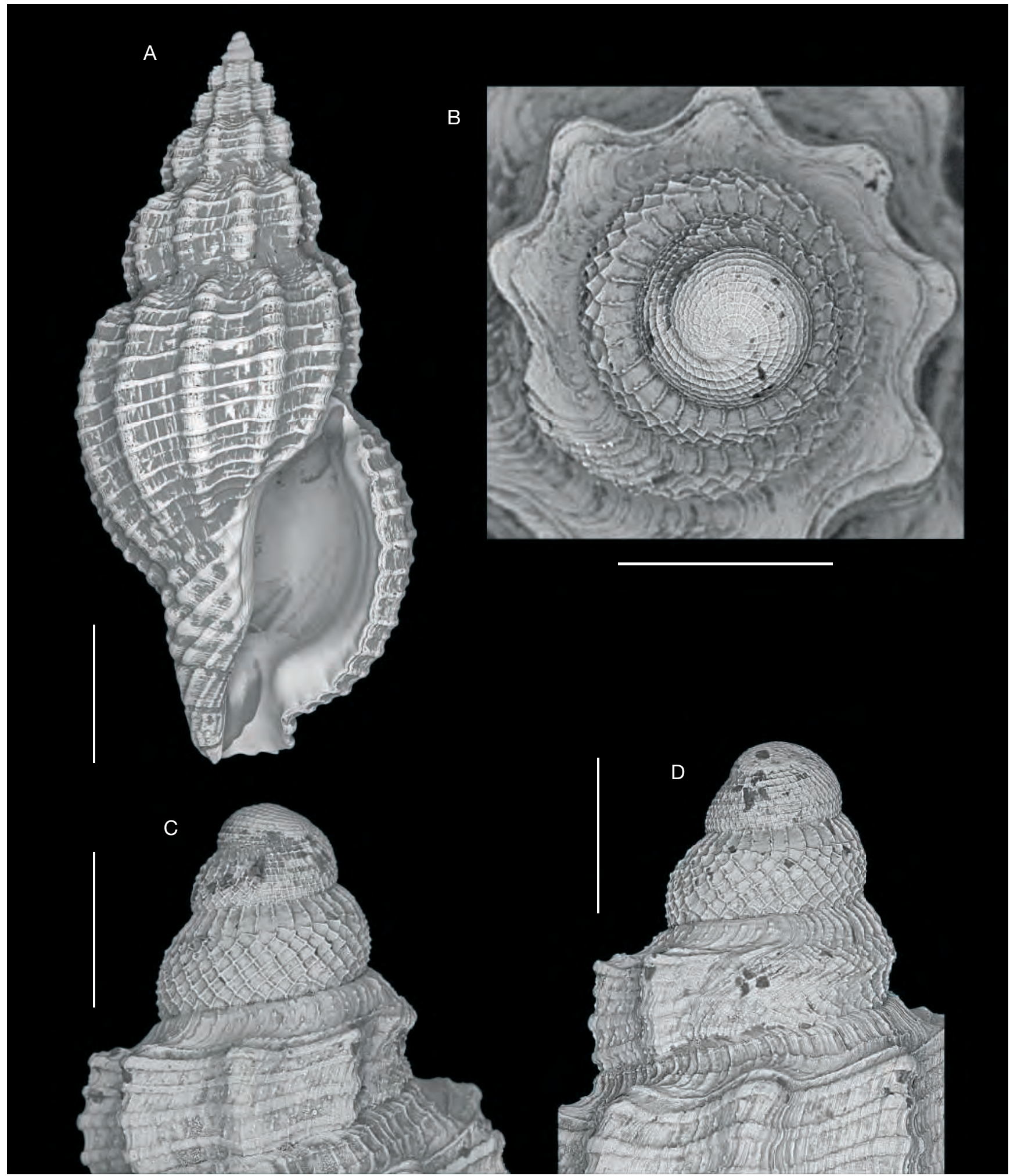

FIG. 13. - Leufroyia concinna (Scacchi, 1836). Dugi Otok Island (Croatia), 32-40 m, h. 10.53 mm. A, Frontal view of shell. B-D, apical (B), frontal (D) and dorsal (C) view of protoconch. Scale bars: $2 \mathrm{~mm}(\mathrm{~A}), 300 \mu \mathrm{m}$ (B-D).

32-40 m; coll. PRK • 5 sh; Dugi Otok I., Nozdre bay; 1 -10 m; coll. PRK - 29 sh; Murter I., Kosirina bay; 1-7 m; coll. PRK • 1 sh; Žirje I.; amidst red coral colonies; 70-100 m; coll. PRK $\bullet 6$ sh; Primošten, Šparadići; 2-6 m; coll. PRK • $20 \mathrm{sh}$; Sevid; 2-6 m; coll. PRK 2 sh; Voluja; 30-50 m; coll. PRK • 6 sh; Jabuka I.; $15-35$ m; coll. STA
- 13 sh; Jabuka I.; 15-35 m; coll. UGA • 4 sh; Čiovo I., Fumija; $10 \mathrm{~m}$; coll. UGA • 7 sh; Šolta I.; 3-15 m; coll. STA • 2 sh; Šolta I.; 3-15 m; coll. UGA 10 sh; Split; 1-6 m; coll. PRK • 1 sh; Split; 10 m; coll. UGA 15 sh; Brač I., Milna; 7-10 m; coll. PRK・19 sh; Brač I., Milna; 7-10 m; coll. STA • 1 sh; Brač I., Maslinova bay; 3-15 m; 
coll. PRK • 74 sh; Brač I., Maslinova bay; 3-15 m; coll. STA $\bullet 14$ sh; Omiš, Balića Rat; 4-8 m; coll. PRK • 1 sh; Brela; 5 m; coll. PRK - 18 sh; Lastovo I.; amidst red coral colonies, 70-100 m; coll. PRK - 6 sh; Lastovo I.; amidst red coral colonies, 70-100 m; coll. STA - 1 sh; Lastovo I.; 50 m; coll. BAR • 5 sh; Pelješac, Prapratno; 2-6 m; coll. PRK • 2 sh; Mljet I., Pod Škoji; 1-3 m; coll. PRK・ 48 sh; Mljet I., amidst red coral colonies; 70-100 m; coll. PRK 11 lv; Biograd; 435 '51"N, 15²6'42"E; BAU-2254.1.

Greece -3 sh; Kato Achaia; coll. CRO $\bullet 1$ sh; Sane; coll. CRO - 1 sh; Crete Island, Elounda; coll. DSC $\bullet 2$ sh; Korinthiakos Gulf 60-120 m; coll. KON • 4 sh; Saronic Gulf; 30-70 m; coll. KON - 2 sh; Pylos; 6 m; coll. PAG.

Turkey 1 sh; unprecised locality; coll. CGS • 1 sh; Göçek, Sarsala Bay; coll. CGS $\bullet 1$ sh; Didim; 50-100 m; coll. CGS • 1 sh; Izmir Bay; $28 \mathrm{~m}$; coll. OZT 1 sh; Datça; coll. TRI • 1 sh; Mersin, Soguksu; coll. TRI.

Distribution. - Early-late Pliocene: Northern Italy (Sacco 1904); Altavilla, Palermo, Italy (Cipolla 1914); Pliocene, Piedmont, Italy (Tropeano et. al. 1984); Rio Albonello, Emilia-Romagna (Tabanelli \& Segurini 1994); Tuscany, Italy (Chirli 1997).

Recent: Northeastern Atlantic from Norway to Canary Islands. The entire Mediterranean. Common on rocky bottoms at 1-100 m depth. Collected alive under stones or amidst algae, and in sciaphilous habitats, including amidst red coral colonies where it is quite frequent. It often lives in sympatry/syntopy with other raphitomids, also with other Leufroyia spp.; in shallow water it is frequently found with $L$. leufroyi even under the same stone or amidst the same algae.

Original DESCRIPTION. - "Pleurotoma concinna Nobis (18) Testa albo-sordida, lineis transversis rubro-fuscis inconcinne ornata; transversim striata; per longum costata; apertura dilute violacea. Alta lin. 7-8. P. C. similis at minor, gracilior, striis transversis rariobus et diversa colorum pictura. In sinu neapolitano et tarentino parum frequens. Consule" Fig. 18 (Scacchi 1836:13).

\section{DESCRIPTION}

\section{Shell}

Solid and fusiform, of medium size for the genus. Height: 9.0$15.17 \mathrm{~mm}$ (mean $11.8 \mathrm{~mm}$, SD: 1.69); width: 3.3-7.91 mm (mean $5.32 \mathrm{~mm}, \mathrm{SD}: 0.81$ ); H/W: 1.84-2.77 (mean 2.24, SD: 0.18).

\section{Protoconch}

Multispiral with 2.4 to 2.9 (mean 2.66, SD: 0.14) convex whorls and small nucleus $(\mathrm{d}: 140 \mu \mathrm{m})$. Protoconch I of 1.0 whorl, diameter $265 \mu \mathrm{m}$, covered by dense cancellate sculpture; protoconch II with axial threads under the suture and less dense and diagonally cancellate sculpture on rest of whorl. A keel at the end of last whorl of varying length or absent. Protoconch-teleoconch boundary of flexuose, opisthocline growth lines. Colour usually brown with white nucleus, sometimes purplish-brown, rarely very light with pinkish hue, never dark brown or blackish. Transition from protoconch to teleoconch well visible by contrasting colours, brown $v$ s pink or purple.

\section{Teleoconch}

Of 5.2-7.0 convex whorls (mean 6.16, SD: 0.48), with deep and distinct wavy sutures and prominent axial sculpture; suture area slightly thickened abapically and white coloured with brown dots or lines; whole external surface covered with relatively thick periostracum; dense and rough axial riblets (growth lines) present on ribs, interspaces, and on subsutural ramps; microgranules over the whole surface, scattered on 2-3 adapical whorls and dense on others.

Axial sculpture of 10-16 (mean 12.93, SD: 1.53)] strong, equidistant, orthocline or slightly opisthocline ribs slightly broader, equal or narrower than interspaces.

Spiral sculpture of 9-16 narrow and low cords (mean 11.53, SD: 1.74) above the aperture, of which 3-4 weak on subsutural ramp, remaining of almost equal strength and equally spaced, or with few additional thin cordlets between the strongest cords, occasionally one thin cordlet between all pairs of strong cords; interspaces 2-4 times broader than cords; on first adapical whorl 4 spiral cords almost equal in strength and one thin subsutural above them.

Siphonal fasciole with 6-9 (mean 7.86, SD: 0.75) strong and slightly nodulose cords, stronger than cords of body-whorl.

Cancellation rectangular to squared, with very elongate and slightly elevated tubercles at intersections.

Subsutural ramp narrow and inclined, covered with dense growth marks of the anal sinus, crossed by 3-4 weak spiral cordlets.

Columella simple, straight medially and arcuate or angled posteriorly. Siphonal canal wide and short, posterior canal deep and moderately wide.

Outer lip thickened and smooth internally, with edge crenated by spiral cords.

Height of aperture: 3.46-6.42 mm (mean $4.86 \mathrm{~mm}$, SD: 0.74$)$; A/H: 35.92-46.79\% (mean 41.13\%, SD: 2.50 ).

\section{Coloration}

Background colour light, from whitish to pale brownish, with pinkish, purple or purplish-brown areas present always on 1-3 adapical whorls, often inside aperture, on subsutural ramps and in interspaces between axial ribs, frequently darker above a median spiral brown cord. Some spiral cords completely or partially dark brown or reddish-brown, occasionally light brown, orange or yellowish, rarely only slightly darker than background; a broad light spiral band almost devoid of blotches at aproximately $1 / 3$ to $1 / 2$ of whorl height; a brown band often below periphery. Cords on siphonal fasciole light with some tubercles of intense brown or brownish-orange colour. Aperture white or pinkish.

\section{Soft parts}

Foot very long, broad and deeply bilobed anteriorly and with recurved anterolateral corners, narrowly tapering posteriorly. Siphon cylindrical with ventral slit, widely opening anteriorly, very extensile. Head small with a pair of long cylindrical tentacles, black eyes on bulges about halfway their length, distal part slightly longer and much narrower than basal. Operculum absent, toxoglossate radula present (G.O. Sars 1878: pl. VIII, fig. 2).

Colour translucent white with minute white speckles densely covering upper side of foot, scattered or absent on sole, head and along neck. Tentacles translucent white, with or without white speckles along entire lenght. Siphon translucent white or yellowish-white, with less dense white speckles. 


\section{REMARKS}

L. concinna has been largely misidentified as L. leufroyi by many authors, old and modern.

The maximum height of examined shells is $16 \mathrm{~mm}$, but shells larger than $14 \mathrm{~mm}$ are rare. The height and maximum diameter of the protoconch depend on the number of whorls; in the specimen of Fig. 13, with 2.75 protoconch whorls, the protoconch is $580 \mu \mathrm{m}$ high and $504 \mu \mathrm{m}$ wide. The diameter of nucleus and first whorl are small and similar to L. leufroyi, smaller than in L. erronea and L. villaria. The colour of protoconch varies geographically, mostly brown in some areas (e.g. Adriatic Sea), purple or purplish-brown in others (e.g. Tyrrhenian Sea). The sexes are separated (male and female reproductive systems are described by E.H. Smith (1967) under the name Philbertia leufroyi boothi), but we did not find any evidence of bimodality in morphometrics, thus guessing no size dimorphism is present.

Diagnostic features of L. concinna from all other Leufroyia spp. are the constant presence of pinkish or purple areas on parts of the shell, the numerous brown spiral cords on all whorls recalling the colour pattern of Cyrillia linearis (Montagu, 1803), and the more intense brown colour of tubercles on the siphonal fasciole (although shells tend to fade out after some years from collection). A few shells may look more homogeneously coloured with very light spiral cords, but also in such cases the pinkish colour of at least the first teleoconch whorl is always diagnostic. We have observed that specimens stored in 96-100\% ethanol does not change significantly intensity of colours after some years, whilst those stored in $70 \%$ ethanol or formalin do fade out rapidly and significantly. There is some geographic variation in colour and sculpture: almost uniformly dark brown shells are not known from the Mediterranean; some Atlantic specimens have stronger and broader spiral cords than Mediterranean ones, also the axial ribs can be very weak or absent on the body whorl (Høisæter 2016). Some specimens from Canary Islands are smaller (max. $10 \mathrm{~mm}$ ), more slender and with a colour pattern recalling $L$. leufroyi (Fig. 10I-K). The northermost record (Høisæter 2016) is from southern Lofoten Islands at $67^{\circ} 10.7^{\prime} \mathrm{N}$, $14^{\circ} 20.3^{\prime} \mathrm{E}$. The southernmost record is from Canary Islands. We have no confirmed records from the Açores and Madeira.

\section{Leufroyia erronea Monterosato, 1884}

(Figs 14-16)

Defrancia leufroyi var. coralligena Monterosato, 1872:51 (nomen nudum).

? Defrancia convexa Jeffreys, 1882: 33.

Leufroyia erronea Monterosato, 1884: 134.

Clathurella erronea - Locard \& Caziot 1899: 63 (? L. villaria).

Comarmondia inflata - sensu Chirli 1997: 91, pl. 26, figs 5, 6 non De Cristofori \& Jan, 1832.

Leufroyia erronea - Carus 1893: 428 [in synonymy with Clathurella inflata (De Cristofori \& Jan, 1832)] - Cipolla 1914: 72 (176) [in synonymy with Peratotoma (Leufroyia) inflata sensu Cipolla 1914 non De Cristofori \& Jan, 1832] - Pallary 1900: 257 - Van Aartsen 1988: 142.

Pleurotoma (Leufroyia) leufroyi erronea - Kobelt 1905: 366, no. 22.
Pleurotomella demosia - sensu Bogi 1986: 27-28 non Dautzenberg \& Fischer, 1896 - sensu Crocetta \& Spanu 2008: 67, 72, fig 3A, B non Dautzenberg \& Fischer, 1896 - sensu Giribet \& Peñas 1997: 52, Figs 66-68 non Dautzenberg \& Fischer, 1896 - sensu Negri \& Corselli 2016: 69, fig. 15Q-T non Dautzenberg \& Fischer, 1896 sensu Scaperrotta et al. 2012: 99 non Dautzenberg \& Fischer, 1896.

Raphitoma (Leufroyia) erronea - Piani 1980: 156 - Sabelli et al. 1990: 44, 216.

Raphitoma (Leufroyia) leufroyi erronea - Nordsieck 1968: 179.

Raphitoma (Leufroyia) sp. De Casa \& Hallgass, 1979: 11 pl. 1 (3-4).

Raphitoma erronea - Poppe \& Goto 1991: 44, 174 - Peñas \& Giribet 2003: 181 - Repetto et al. 2005: 39, 218, fig. 895 (uncertain, very badly figured) - Pusateri \& Giannuzzi-Savelli 2008: 124, fig. 15 Cossignani \& Ardovini 2011: 31, 325 (figured) - Appolloni et al. 2018: 60-61, 112, fig 22M, N - Ceulemans et al. 2018: 113 Manousis et al. 2018: 21, fig.11A-E.

Type MATERIAL. - Leufroyia erronea Monterosato: Syntypes. Sardinia $\bullet 1$ sh; Sardinia, unprecised locality; Tiberi's handwriting label, "Defrancia volutella Valenciennes Sardegna", H: 15.8 mm, W: $7.5 \mathrm{~mm}, \mathrm{H} / \mathrm{D}=2.1$; MCZR-M-16704-L. Mediterranean • $1 \mathrm{sh}$; unprecised locality; Monterosato handwritten label "Leufroya erronea, Monts. in Nom. gen. e sp. p. 126 Adr. (Stossich) Palermo (Monts)", H: $10.2 \mathrm{~mm}$, W: $4.9 \mathrm{~mm}$. Defrancia convexa Jeffreys: type material lost (Warén 1980: 33); MCZR-M-17340-L.

TYPE LOCALITY. - Leufroyia erronea Monterosato: Originally described from Corsica (France), Sardinia, Palermo to San Vito lo Capo (Sicily) and Dalmatia (Croatia). Defrancia convexa Jeffreys: West of Italy.

Material examined. - Atlantic. Great Britain -7 sh; Shetland Islands; USNM Jeffreys coll. • $1 \mathrm{sh}$; Moray Firth; under leufroyi; NMW 01065.

Spain $\bullet 1$ sh; Galicia; coll. HOU.

Açores • 1 sh; São Miguel I., Ponta Delgada; 18 m, Josephine exp. 1869 • 1 sh; SMNH 70501; São Miguel; SMNHN 70499.

Madeira 2 sh; unprecised locality; sub nomine Defrancia leufroyi with handwritten label by Watson; MCZR-M 16704.

Mediterranean. Spain 1 sh; unprecised locality; coll. GUB $\bullet 1$ sh; Malaga; coll. PUS.

Corsica 1 sh; Capo Corso; coll. BAR.

Sardinia $\bullet 5$ sh; Alghero; coll. SPM.

Sicily 1 sh; Isola delle Femmine; coll. PUS.

Italy $\bullet 1$ sh; Gorgona I.; coll. PAG • 1 sh; Capraia I.; coll. CAM - 1 sh; Livorno, Bagni Fiume; coll. PAG $\bullet 1$ sh; off Fiumicino; 300 m; coll. PAG • 2 sh; Napoli; Tiberi label; MCZR-M-1730.

Croatia • 4 sh; Molat I.; 35-50 m; coll. PRK • 3 sh; Žirje I.; 70-100 m; coll. PRK • 78 sh; Lastovo I.; 70-100 m; coll. PRK • 43 sh; Lastovo I.; 70-100 m; coll. STA • 110 sh; Mljet I.; 70-100 m; coll. PRK • 6 sh; Mljet I.; 70-100 m; coll. TIS • 3 sh; Dugi Otok I., Veli Garmenjak; 32-40 m, rocky bottom; coll. PRK $\bullet 1$ sh; Voluja; 40-60 m, rocky bottom; coll. PRK $\bullet 3$ sh; Jabuka I.; 30 m, rocky bottom; coll. STA - 14 sh; off Dubrovnik; 300-380 m, soft bottom; coll. LET.

Greece 1 sh; Saronic Gulf; coll. KON.

Distribution. - North East Atlantic from Great Britain to Portugal, and the whole Mediterranean Sea. More frequently collected on rocky bottoms, from a depth of $c a .30 \mathrm{~m}$ to more than $100 \mathrm{~m}$, than dredged from deep soft bottoms (100-400 m). In Croatia, L. erronea is the commonest raphitomid amidst the red coral colonies. Often found in sympatry/syntopy with other raphitomids, also with other Leufroyia spp.

ORIGINAL DESCRIPTION. - " = P. volutella, (non Valenc.) auct. = ? P. fortis, Forbes - Rep. 1843, p. 196 - Reeve t. 19, f. 165 (Mar Egéo). Coralligena, rarissima in Corsica e Sardegna (Tiberi); Palermo a S. Vito (Monts.); Dalmazia (Brusina)" (Monterosato 1884: 134). 


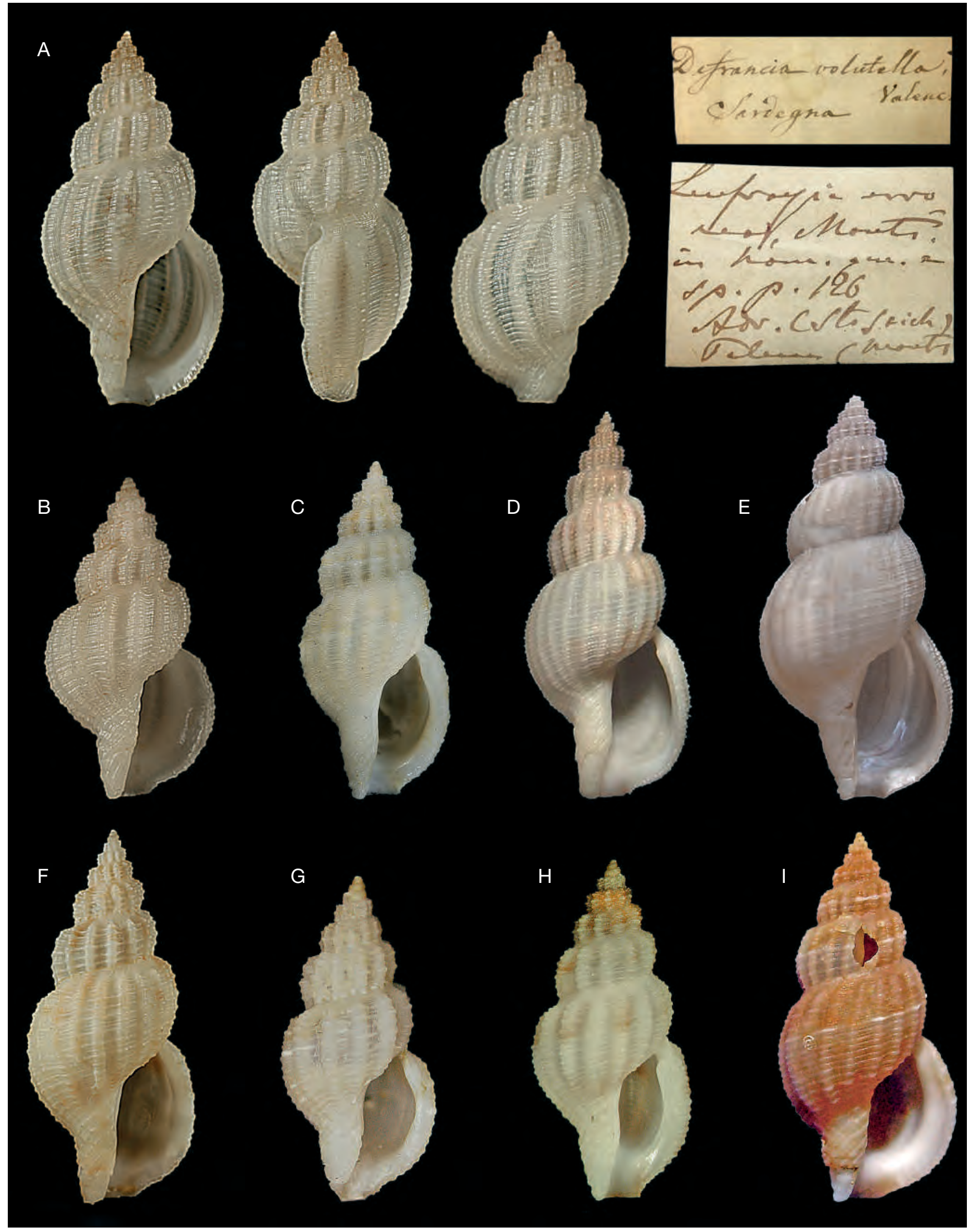

FIG. 14. - Leufroyia erronea Monterosato, 1884: A, Sardinia (Italy), h. $15.8 \mathrm{~mm}$, with original labels by Tiberi and Monterosato; B, sine loco, h. $10.5 \mathrm{~mm}$; C, Gorgona Island (Italy), h. 12.5 mm; D, Spain, h. 24 mm; E, Capraia Island (Italy) 120 m, h. 27 mm; F, Latium (Italy), h. 15.5 mm; G, Capo Corso (Italy), h. 8.5 mm; H, Mljet Island (Croatia) 70-100 m, h. 10.6 mm; I, Mljet Island (Croatia) 70-100 m, h. 15.7 mm. Photo courtesy: D, Peter Stahlschmidt, E, Enzo Campani, H, Morena Tisselli. 


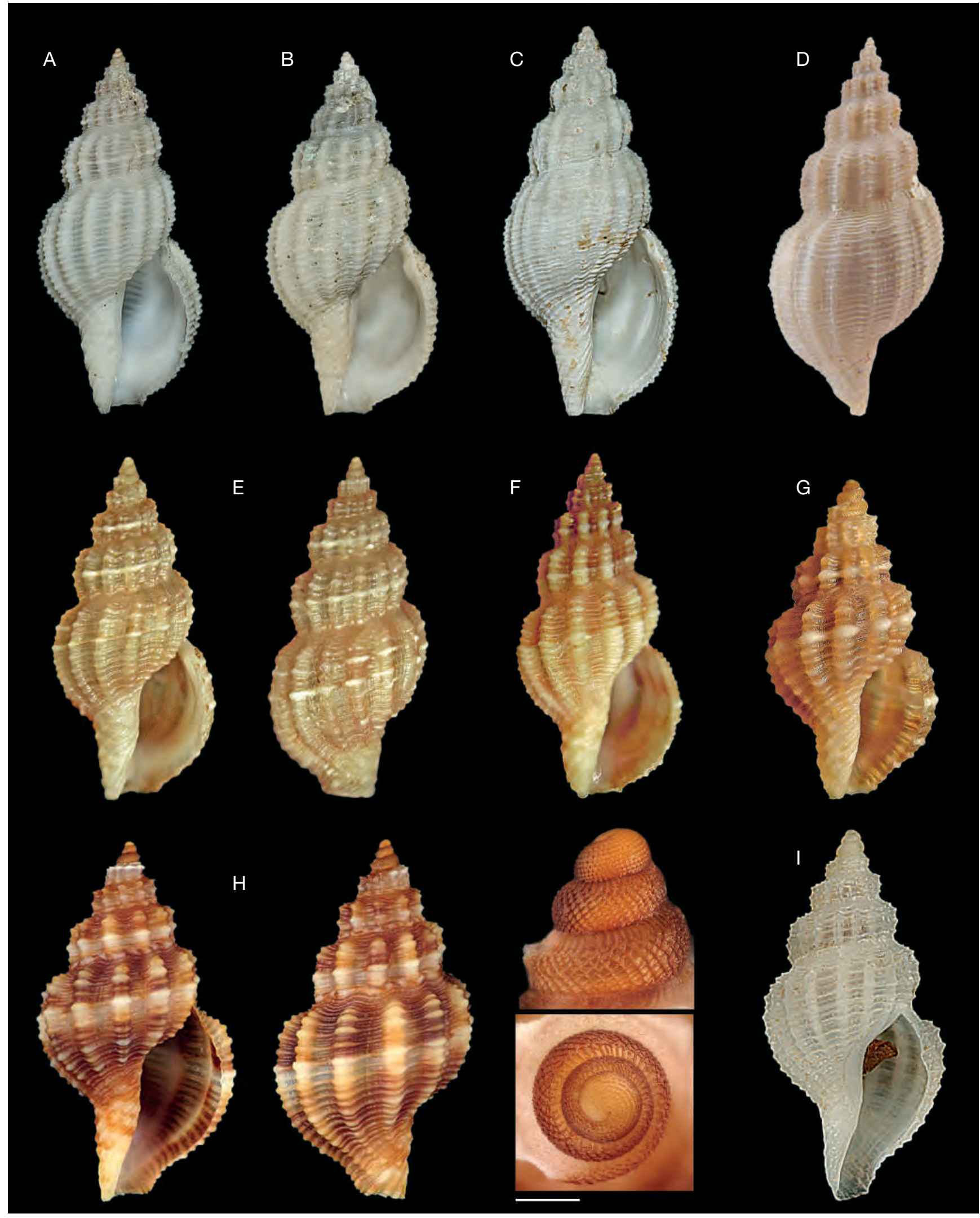

FIG. 15. - Leufroyia erronea Monterosato, 1884. A, Syntype, Shetland Islands (USNM 190581 ex Jeffreys coll.), h. 14.8 mm; B, Shetland Islands (USNM 190582 ex Jeffreys coll.), h. 14.5 mm; C, Shetland Islands (USNM 190578 ex Jeffreys coll.), h. 19.4 mm; D, Galicia (Spain), h. 16.2 mm; E, Mljet Island (Croatia), $70-100$ m, amidst red coral colonies, h. $9.1 \mathrm{~mm}$; F, Mljet Island (Croatia), 70-100 m, amidst red coral colonies, h. $8.3 \mathrm{~mm}$; G, Mljet Island (Croatia), $70-100 \mathrm{~m}$, amidst red coral colonies, h. $5.3 \mathrm{~mm}$; H, Saronic Gulf (Greece), h. $6.15 \mathrm{~mm}$ - scale bar 200 um. I, Pleurotomella demosia (Dautzenberg \& Fischer, 1896), Açores (MNHN), 1300 m, 38³3'21"N, 30²8'54" W, h. 7.3 mm. Photo courtesy: A-C, Jolanda Villacampa (USNM); H, Costas Kontadakis. 


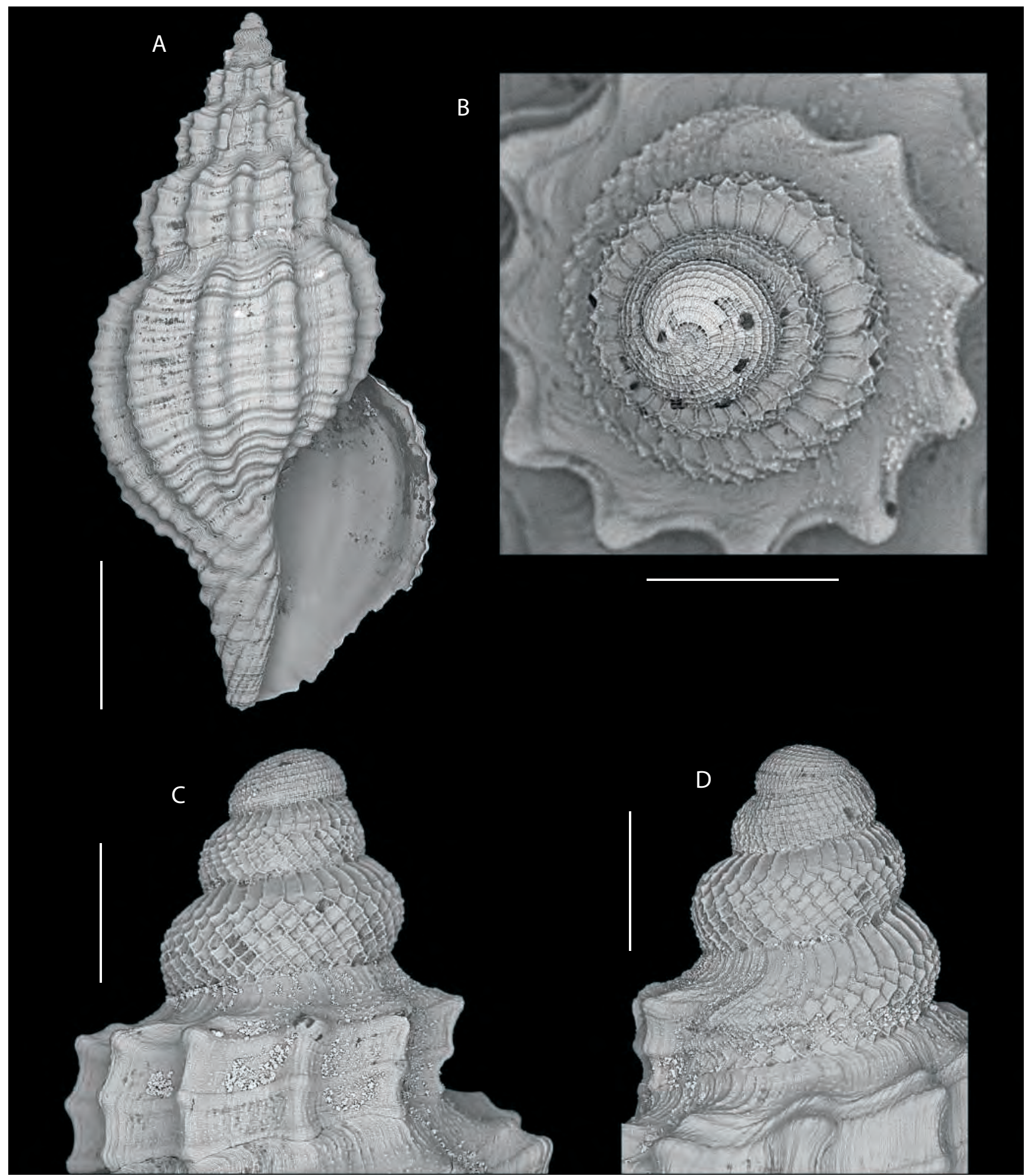

FIG. 16. - Leufroyia erronea Monterosato, 1884. Žirje Island (Croatia), 70-100 m, amidst red coral colonies, h. 9.32 mm. A, Frontal view of shell. B-D, apical (B), frontal (D) and dorsal (C) view of protoconch. Scale bars: $2 \mathrm{~mm}(\mathrm{~A}), 300 \mu \mathrm{m}(\mathrm{B}-\mathrm{D})$

\section{DESCRIPTION}

Shell

Solid and suboval, of large size for the genus. Height: 9.04 $20.8 \mathrm{~mm}$ (mean $13.52 \mathrm{~mm}$, SD: 3.35); width: 4.4-8.8 mm (mean $6.28 \mathrm{~mm}, \mathrm{SD}: 1.36$ ); H/W: 1.95-2.36 (mean 2.15, SD: 0.11).

\section{Protoconch}

Multispiral with 2.55 to 3.1 (mean 2.82 , SD: 0.15 ) convex whorls and large nucleus (d: $172 \mu \mathrm{m})$. Protoconch I of 1.15 whorls, diameter $315 \mu \mathrm{m}$, covered by dense cancellate sculpture; protoconch II with axial threads under the suture 
and less dense and diagonally cancellate sculpture on rest of whorl. A keel at the end of last whorl of varying length or absent. Protoconch-teleoconch boundary of flexuose, opisthocline growth lines. Colour usually light, whitish to brown, occasionally darker brown, never very dark or blackish; with or without white nucleus.

\section{Teleoconch}

Of 4.7-7.15 convex whorls (mean 5.88, SD: 0.68), with deep and distinct wavy sutures and prominent axial sculpture; suture area often slightly thickened abapically; periostracum not observed; whole surface covered with fine and dense axial growth lines and extremely fine microgranules, less dense or scattered on 1-2 adapical whorls and very dense on others.

Axial sculpture of 11-22 (mean 14.89, SD: 2.41) strong, equidistant, orthocline or slightly opisthocline ribs, broader than spiral cords, narrower than interspaces; ribs occasionally very weak and low on body whorl, sometimes also on penultimate whorl, in largest shells.

Spiral sculpture of 12-26 narrow cords (mean 18.18, SD: 3.77) above the aperture, of which 3-4 weak on subsutural ramp, remaining never equally strong due to variable number of thinner cords (number of thinner cords lower than or equal to that of strong ones); interspaces narrower, equal or slightly broader than stronger cords; on first adapical whorl 3 spiral cords equal in strength and one thinner subsutural cordlet.

Siphonal fasciole with 8-16 (mean 11.15, SD: 1.87) strong and nodulose cords, stronger than cords on body-whorl, thinner cords often present between strong ones.

Cancellation rectangular, with elongate and slightly elevated tubercles at the intersections. When the ribs are weak and low, tubercles are also very weak; tubercles usually stronger on first 3-4 whorls.

Subsutural ramp narrow and inclined, covered with dense growth marks of the anal sinus, crossed by 3-4 weak spiral cordlets; ramp on first whorls less inclined; ramps less inclined in shells with strong ribs.

Columella simple, straight medially and angled posteriorly. Siphonal canal very short and wide, posterior canal deep and wide.

Outer lip thickened and smooth internally, with edge crenated by spiral cords.

Height of aperture: 3.8-8.4 mm (mean 5.65, SD: 1.35); A/H: 37.69-46.56\% (mean 42.36\%, SD: 2.02).

\section{Coloration}

Background colour variable but usually light, from whitish to light brown or reddish-brown, rarely dark brown, with areas or blotches of different colour, rarely uniformly coloured. One cord lighter than background, usually white-whitish, above suture, at approximately $1 / 3$ to $1 / 2$ of whorl height, the area above the cord often darker than the rest. Darker blotches and areas irregularly placed on axial ribs and interspaces on upper part of each whorl, sometimes below periphery. Cords on siphonal fasciole always same light colour as background, occasionally with some pale brownish lines in the interspaces.
Aperture internally white or beige, often with some light brownish blotches visible by transparency.

\section{Soft parts}

Unknown.

\section{REMARKS}

We suspect that Defrancia convexa Jeffreys, 1882 may be this species but the type material is lost (Warén 1980: 33). Description (based on a single specimen), size and colour fit relatively well a $L$. erronea with obsolete ribs. But it could be also a L. villaria for its "longer spire ... and the canal is not so short and abrupt" (Jeffreys 1882: 33). Therefore, we consider for the moment Defrancia convexa as nomen dubium.

Leufroyia erronea was proposed by Monterosato (1884: 134) to distinguish a specimen received around 1878 by Tiberi, as Pleurotoma volutella Kiener, 1839 ex Valenciennes ms. (Monterosato 1878: 106), considered to be a distinct species. Only in 1884, after the acquisition of Tiberi collection, Monterosato realized that misidentification and named erronea this species (see also Carus 1893: 428; Cipolla 1914: 72). The misidentification by Tiberi is quite strange as his specimen is very different from Kiener's P. volutella (see Fig. 21D).

The height and maximum diameter of the protoconch depend on the number of whorls; in the specimen of Fig. 16, with 3 protoconch whorls, the protoconch is $715 \mu \mathrm{m}$ high and $596 \mu \mathrm{m}$ wide. The diameter of nucleus and first whorl are quite large and similar to L. villaria, larger than in L. leufroyi and L. concinna.

The maximum height of examined shells is $27 \mathrm{~mm}$, but shells larger than $18 \mathrm{~mm}$ are rare. The largest shell $(27 \mathrm{~mm})$ found so far was dredged from a depth of $120 \mathrm{~m}$ at Capraia Island, Italy (Fig. 14E).

Diagnostic features of L. erronea with all other Leufroyia spp. are the suboval profile, the wide aperture, the very short siphonal canal and the stronger and less spaced spiral cords. It differs from L. concinna also in the lack of brown coloured cords and pinkish/purple areas, and in its larger protoconch. From L. leufroyi it differs in the lack of dark brown or blackish blotches and in its larger protoconch, which is never very dark or blackish. L. villaria has a more slender shell, more stepped whorls and thinner spiral cords. After some years from collection the coloration tends to fade out, with shells becoming lighter and almost uniformly coloured.

The specimen MCZR-M-16704 from Sardinia, labeled by Tiberi as Defrancia volutella, has been figured by Pusateri \& Giannuzzi-Savelli (2008: 123, fig. 15, as "holotype" and with wrong measures) and by Appolloni et. al. (2018: 112, fig. 22M, N, with wrong catalog number).

Specimens of $L$. erronea have been frequently identified erroneously as Pleurotomella demosia (Dautzenberg \& Fischer, 1896) an Atlantic species, the actual presence of which in the Mediterranean is very doubtful (Fig. 15I). Small specimens of L. erronea have strong axial and spiral sculpture (Fig. 15G-H), making confusion easier with similarly sized specimens of P. demosia: the two species have protoconch with similar ranges of whorls number (2.5-3, see Bouchet \& Warén 1980: 
fig. 226) but $P$. demosia has a lower protoconch (H: $550 \mu \mathrm{m}$ [Bouchet \& Warén 1980] v. 650-720 $\mu \mathrm{m}$ in L. erronea). In fact, several Mediterranean records of $P$. demosia (e.g. Bogi 1986; Giribet \& Peñas 1997; Crocetta \& Spanu 2008; Scaperrotta et al 2012; Negri \& Corselli 2016) are based on misidentification with L. erronea. Adriatic and Aegean specimens generally are smaller and more vividly colored than those in the central-western basin.

Leufroya villaria (Pusateri \& Giannuzzi-Savelli, 2008) (Figs 17-20)

Raphitoma villaria Pusateri \& Giannuzzi-Savelli, 2008: 119, figs 1-4, $6,8,10-12,18$

Peratotoma (Leufroyia) inflata - sensu Cipolla 1914: 72 non De Cristofori \& Jan, 1832.

Philbertia leufroyi-sensu Knudsen 1952: 173, pl. 2, fig. 11; 1956: 527 , pl. 2, figs 16, 17 non Michaud, 1828.

Pleurotoma volutella - sensu Aradas \& Benoit 1876: 251 non Kiener, 1839 - var. B sensu Brugnone 1862: 27 non Kiener, 1839.

Pleurotomella sp. - Peñas et al. 2006: 126, figs 274-276.

Raphitoma (Leufroyia) erronea - sensu Mifsud 2003: 44, fig. 15 non Monterosato, 1884.

Raphitoma cf. erronea - sensu Cachia et al. 2001: 66, pl. 10, fig. 3 non Monterosato, 1884.

Raphitoma leufroyi - sensu Ardovini \& Cossignani 2004: 38, 225 [only the fourth of first row] non Michaud, 1832 - sensu Rolán et al. 1998: 108, figs 26-28 non Michaud, 1828.

Raphitoma villaria - Cossignani \& Ardovini 2011: 328 (figured) Manousis et al. 2018: 24, fig. 18A-E.

Type Material. - Holotype. Sicily 1 sh; Taormina; $15 \mathrm{~m}$; H: 17.3 mm, W: $6.8 \mathrm{~mm}$; MNHN-IM-2000-27244.

Paratypes. Malta 1 sh; Ras il-Wahx; 80-100 m; paratype A, H: $11.5 \mathrm{~mm}$, W: $4.6 \mathrm{~mm}$; MNHN-IM-2000-23353 1 sh; Ras ilWahx; 80-100 m; paratype B, H: $14.4 \mathrm{~mm}$, W: $5.6 \mathrm{~mm}$; coll. MIF. Italy 1 sh; Capraia I.; $150 \mathrm{~m}$; paratype C, H: $16.9 \mathrm{~mm}$, W: $6.5 \mathrm{~mm}$; coll. GOR.

Sicily $1 \mathrm{sh}$; Carini Bay; paratype D, H: $12 \mathrm{~mm}$, W: $4.8 \mathrm{~mm}$; coll. PUS.

Sardinia - $1 \mathrm{sh}$; unprecised locality; paratype F, H: $9.3 \mathrm{~mm}$, W: $4.7 \mathrm{~mm}$; sub nomine Pleurotoma (Defrancia) volutella with Tiberi's handwritten label); SMNH 70490.

Greece 1 sh; Antiparos I.; paratype E, H: 8.6 mm, W: 3.9 mm; coll. BIN.

TYPE LOCALITY. — Taormina (Messina), bioclastic sediments.

Material eXamined. - Atlantic. Angola - 1 sh; Ilha de Luanda; 40-60 m; leg. S. Gofas, as R. leufroyi; MNHN-IM-2010-11650.

Sáo Tomé \& Príncipe • 1 sh; Príncipe I., S. Antonio beach; coll. Marche Marchad, as R. leufroyi; MNHN-IM-2010-11655.

Ivory Coast • 11 sh; Region d'Abidjan; as R. leufroyi.; MNHN Paris IM-2010-11653, MNHN-IM-2010-11651.

Gambia $\bullet 1 \mathrm{sh}$; SW Cap de Bald; $18 \mathrm{~m}$, as R. leufroyi; MNHNIM-2010-11656.

Senegal • 1 sh; Gorée Bay; coll. Knudsen, as Philbertia leufroyi; MNHN • 1 sh; Region de Dakar; 95 m, coll. Marche Marchad as
R. leufroyi; MNHN-IM-2010-11654 • 1 sh; Sud Ile Madeleine; $48 \mathrm{~m}$, as R. leufroyi; MNHN-IM-2010-11653.

Mediterranean. Spain $\bullet 1 \mathrm{sh}$; unprecised locality; coll. STH $\bullet 1$ sh; Malaga; 80-150 m; coll. PUS.

Sicily 1 sh; Marzamemi; coll. MAC $\bullet 1$ sh; Cannizzaro; coll. BOG - 1 sh; Taormina; coll. PUS.

Italy • 2 sh; Capo Rizzuto; coll. ARD • 1 sh; Porto Cesareo; 70 m; coll. FIO.

Malta 18 sh; Gnejna Bay; 80-100 m; coll. MIF • 5 sh; Qammich; $80 \mathrm{~m}$; coll. MIF • 1 sh; Fomm ir-Riћ; $140 \mathrm{~m}$; coll. PRK • 1 lv; Ras il-Wahx; 80-100 m; BAU 3590.1.

Lybia 1 sh; Misurata; 60-80 m; coll. MIF.

Turkey 1 sh; Bozcaada I.; coll. BAR.

Greece $\bullet 1$ sh; unprecised locality; coll. PUS $\bullet 6$ sh; Saronic Gulf; coll. KON.

Croatia $\bullet 2$ sh; Kvarnerić; 60-90 m; coll. UGA $\bullet 2$ sh; Dugi Otok Island, Veli Garmenjak; 35-57 m; coll. PRK • 2 sh; Voluja; 40$60 \mathrm{~m}$; coll. PRK $\bullet 1$ sh; Jabuka I.; $30 \mathrm{~m}$; coll. STA $\bullet 1$ sh; Hvar Channel; $80 \mathrm{~m}$; coll. STA • $1 \mathrm{sh}$; Lastovo I.; $200 \mathrm{~m}$; coll. UGA - 1 sh; Lastovo I.; coll. BAR $\bullet 2$ sh; Lastovo I.; amidst red coral colonies, 70-100 m; coll. STA • 27 sh; Mljet I.; red coral colonies; 70-100 m; coll. PRK • 12 sh; Mljet I.; red coral colonies; 70-100 m; coll. LET $\bullet 2$ sh; Mljet I.; red coral colonies; 70-100 m; coll. TIS - 2 sh; off Dubrovnik; 350-380 m; coll. LET.

Distribution. - East Atlantic (Senegal to Angola) and the Mediterranean Sea, from Spain to the Aegean Sea. More frequently collected by dredging on soft or mixed bottoms than on rocky bottoms, live specimens from $c a$. $20-30 \mathrm{~m}$ to $400 \mathrm{~m}$. Most Croatian specimens were found amidst red coral colonies (70-100 m depth). It is frequently found in sympatry/syntopy with other raphitomids, also with other Leufroyia spp.

ORIGINAL DESCRIPTION. — "Protoconch multispiral, of 3.25 whorls [sic]. Protoconch I of 1.2, dome shaped whorls, with a sculpture of 8-9 spiral threads, covered by minute tubercles; tubercles tending to become oblong and anastomosing, giving rise to a somewhat clathrate pattern. Protoconch II of slightly more than 2 convex whorls, with a sculpture of only subsutural axial threads on the adapical third, tending to curve adaperturally. On the lower two thirds sculpture of diagonally crossing threads. Sinusigera outer lip at the protoconchteleoconch boundary. Teleoconch of 6-7 whorls, with stepped spire. Subsutural ramp narrow, suborizontal, tending to obliterate after the sixth whorl. Adsutural marks of the anal sinus visible on the ramp. Axial sculpture of 15-18 ribs, narrower than the interspaces, reaching the base. Spiral sculpture of numerous continuous cordlets, 13-16 above the aperture, regularly spaced, on the body whor; 1012 strong cords on the siphonal canal. Aperture suboval, tapering anteriorly. Outer lip, internally smooth. Anal sinus as deep as the interspace between two axial ribs. Inner lip smooth, arcuate posteriorly, straigth medially. Siphonal canal short, open. Background colour yellowish with a ligther narrow band on the lower third of the spire. The spiral cordlets within this band may be slightly stronger that the others. Animal with a short head and two short tentacles. Eyes placed on the external, thickened basal part of the tentacles, at about one third of their total height. Foot narrow and long with two anterior lateral triangular lobes and a pointed posterior end. Colour light yellow with a lighter coloured foot, darker tentacles and black eyes. Siphon much darker (nearly orange) in colour. Operculum absent." (Pusateri \& Giannuzzi-Savelli 2008: 120).

\section{DESCRIPTION}

Shell

Moderately solid, slender, fusiform, of large size for the genus. Height: 10.62-19 mm (mean $14.56 \mathrm{~mm}$, SD: 2.86); width: 4.33-7.94 mm (mean $5.77 \mathrm{~mm}$, SD: 1.02); H/W: 2.292.89 (mean 2.51, SD: 0.14). 


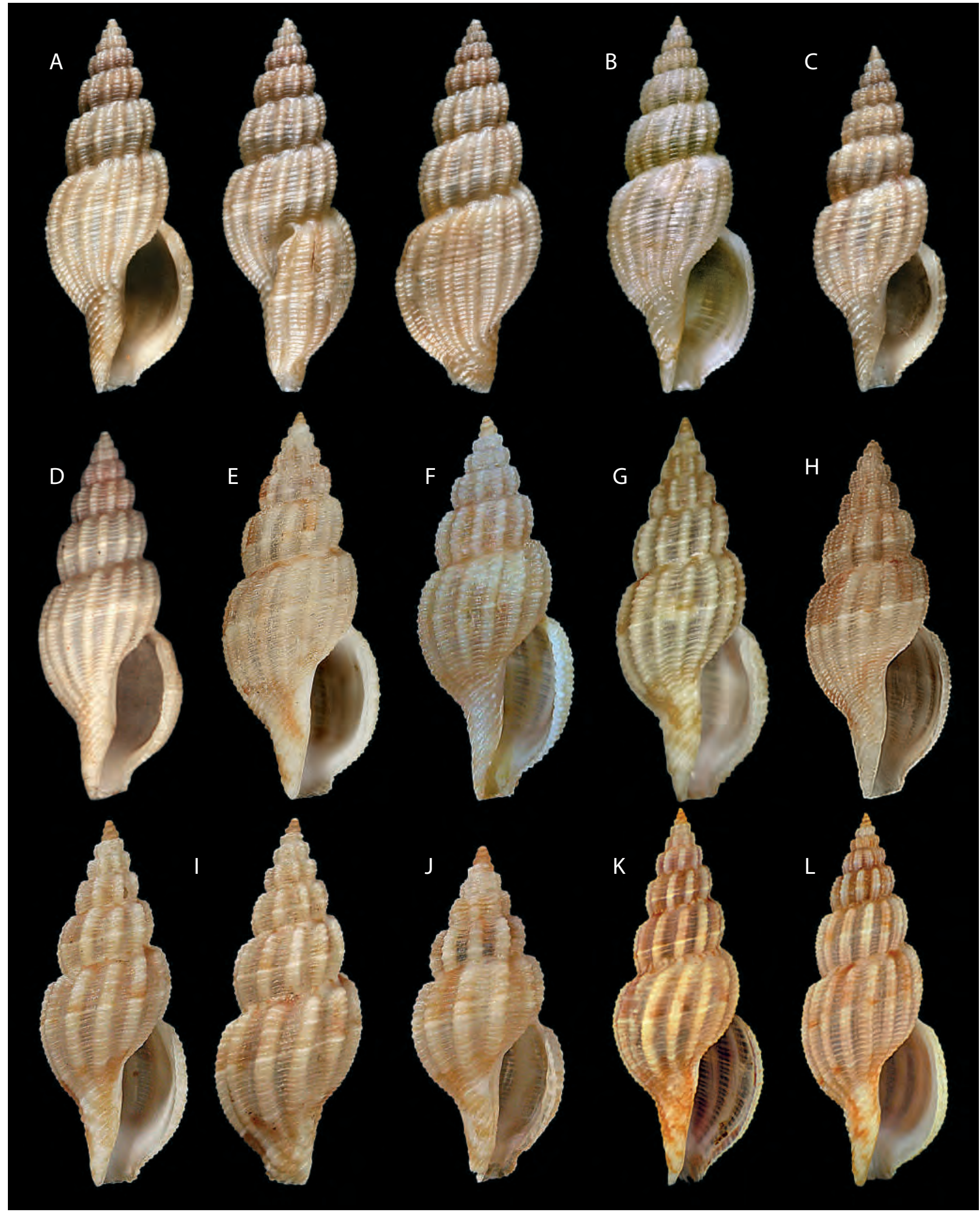

FIG. 17. - Leufroyia villaria (Pusateri \& Giannuzzi-Savelli, 2008): A, holotype (MNHN-IM-2000-27244), Taormina (Italy) -15 m, h. 17.3 mm; B, paratype C (GOR), Capraia Island (Italy) 150 m, h. 16.9 mm; C, paratype A (MNHN-IM-2000-23353), Ras il-Wahx (Malta), 80-100 m, h. 11.5 mm; D, East Sicily (Italy), h. 12.4 mm; E, Porto Cesareo (Taranto - Italy), h. 14.2 mm; F, Fomm Ir-Rih (Malta) 140 m, h. 10.76 mm; G, lonian coasts of Calabria (Italy), h. 13.7 mm; H, Gorée (Senegal) (MNHN, Knudsen coll.), h. $11.4 \mathrm{~mm}$; I, Mljet Island (Croatia), 70-100 m, amidst red coral colonies, h. $10.62 \mathrm{~mm}$; J, Mljet Island (Croatia), 70-100 m, amidst red coral colonies, h. 8.58 mm; K, Saronikos Gulf (Greece), h. 17.1 mm; L, Saronikos Gulf (Greece), h. 16.6 mm. Photo courtesy: D, G, Roberto Ardovini; K, L, Costas Kontadakis. 



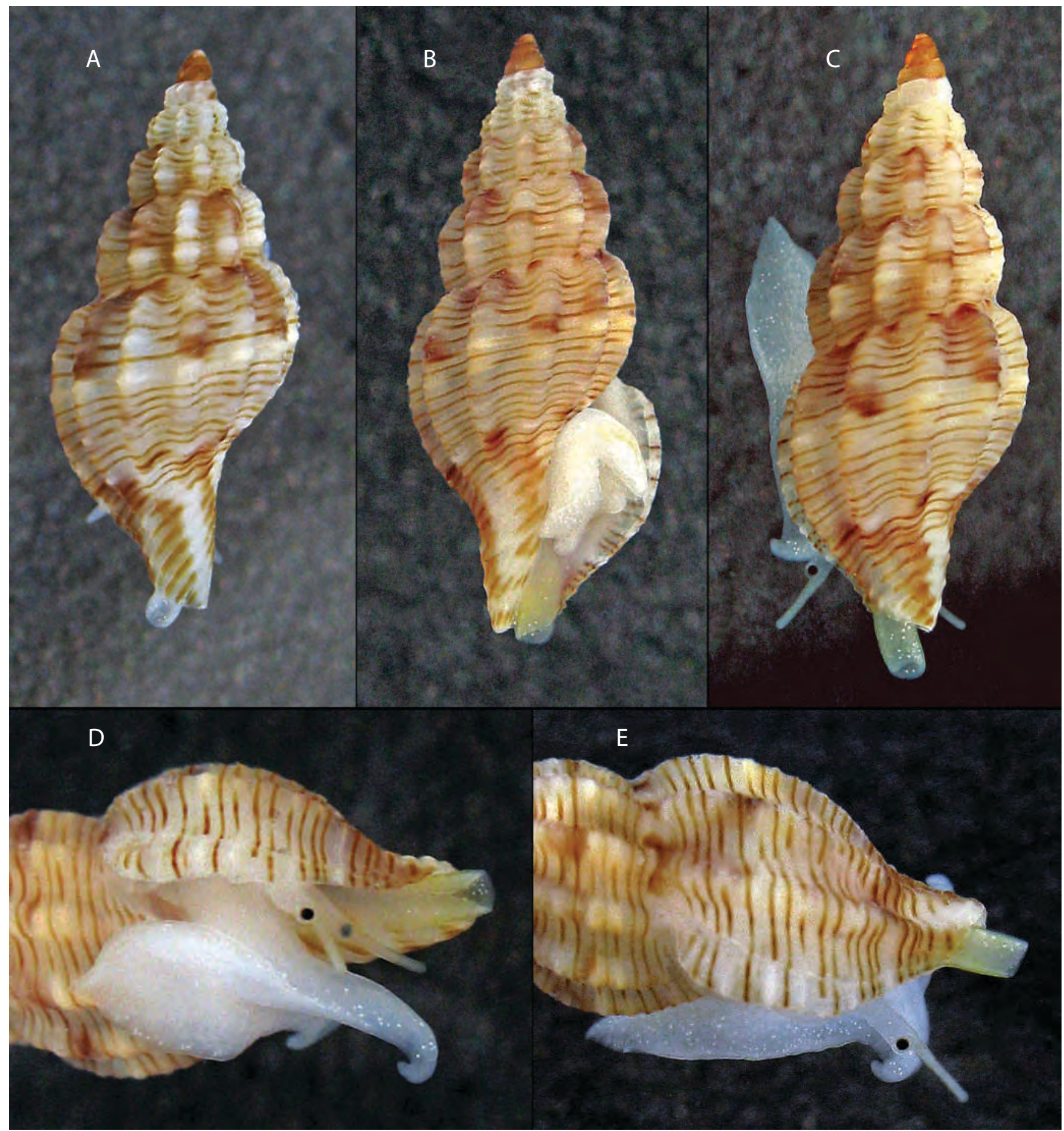

FIG. 19. - Photographs of two living animals of Leufroyia villaria (Pusateri \& Giannuzzi-Savelli, 2008). Dugi Otok Island (Croatia), $35-57$ m, h. 7 mm (A), h. 7.5 mm (B-E). Photo courtesy: Alen Petani.

\section{Protoconch}

Multispiral with 3 to 3.25 (mean 3.1, SD: 0.03) convex whorls and large nucleus $(\mathrm{d}: 170 \mu \mathrm{m})$. Protoconch I of 1.1 whorls, diameter $302 \mu \mathrm{m}$, covered by dense cancellate sculpture; protoconch II with axial threads under suture and less dense and diagonally cancellate sculpture on rest of whorl. A keel at the end of last whorl of varying length or absent. Protoconch- teleoconch boundary of flexuose, opisthocline growth lines. Colour always light, from whitish to light brown, never dark brown or blackish; with or without white nucleus.

\section{Teleoconch}

Of 5.5-7.5 (mean 6.57, SD: 0.59) convex and more or less stepped whorls, with deep and distinct sutures and prominent 


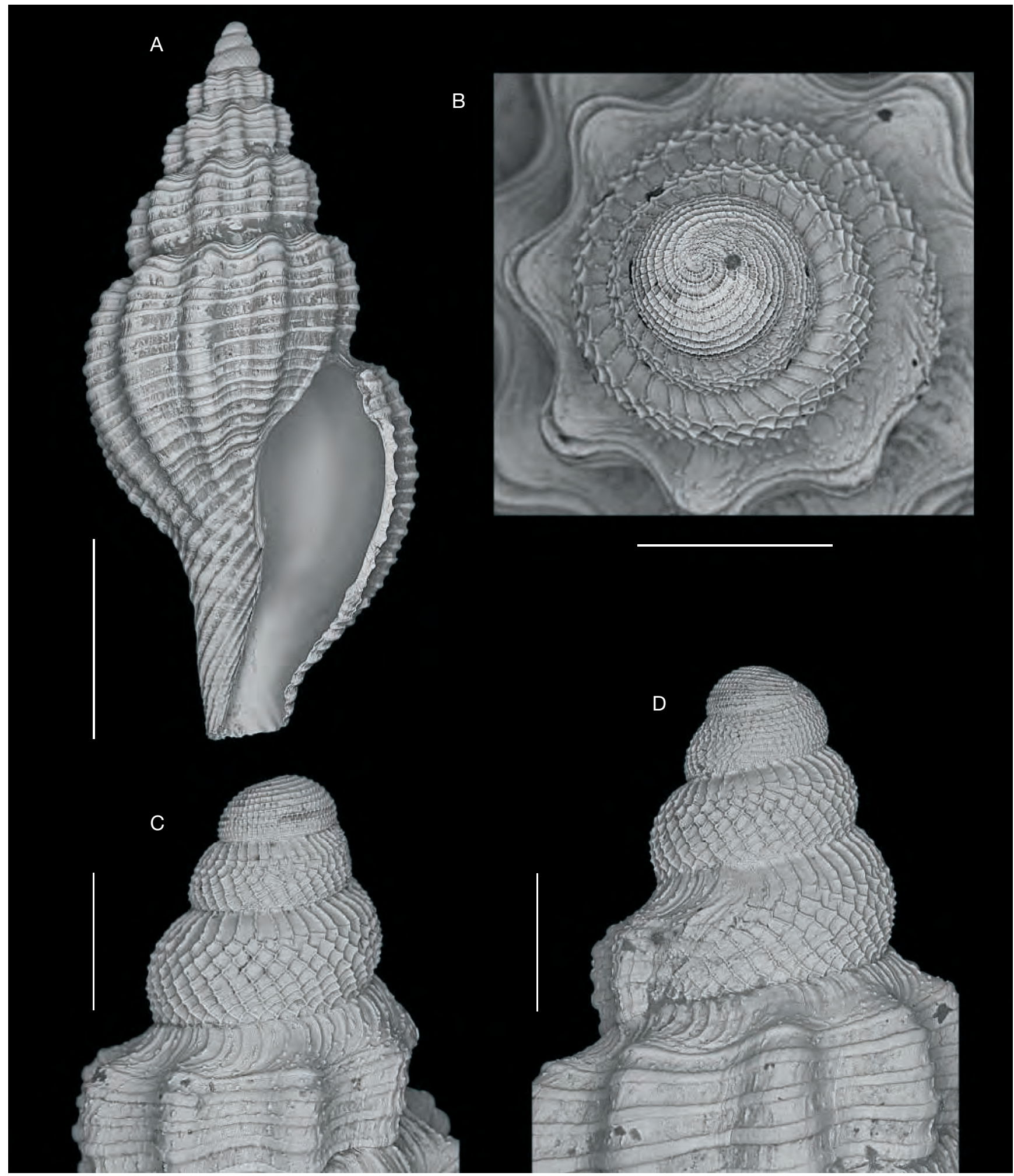

FIG. 20. - Leufroyia villaria (Pusateri \& Giannuzzi-Savelli, 2008). Dugi Otok Island (Croatia), 35-57 m, h. 7.18 mm. A, Frontal view of shell; B-D, apical (B), frontal (D) and dorsal (C) view of protoconch. Scale bars: $2 \mathrm{~mm}(\mathrm{~A}), 300 \mu \mathrm{m}(\mathrm{B}-\mathrm{D})$.

axial sculpture; periostracum very thin, hardly visible and not persistent; whole surface covered with fine and dense axial growth lines and extremely fine microgranules, scattered on 1-2 adapical whorls and very dense on others.
Axial sculpture of 12-17 (mean 14.5, SD: 1.54) strong, equidistant, orthocline or opisthocline ribs (often on the same shell), broader than spiral cords and usually narrower than interspaces. 
- Giannuzzi-Savelli R. et al.

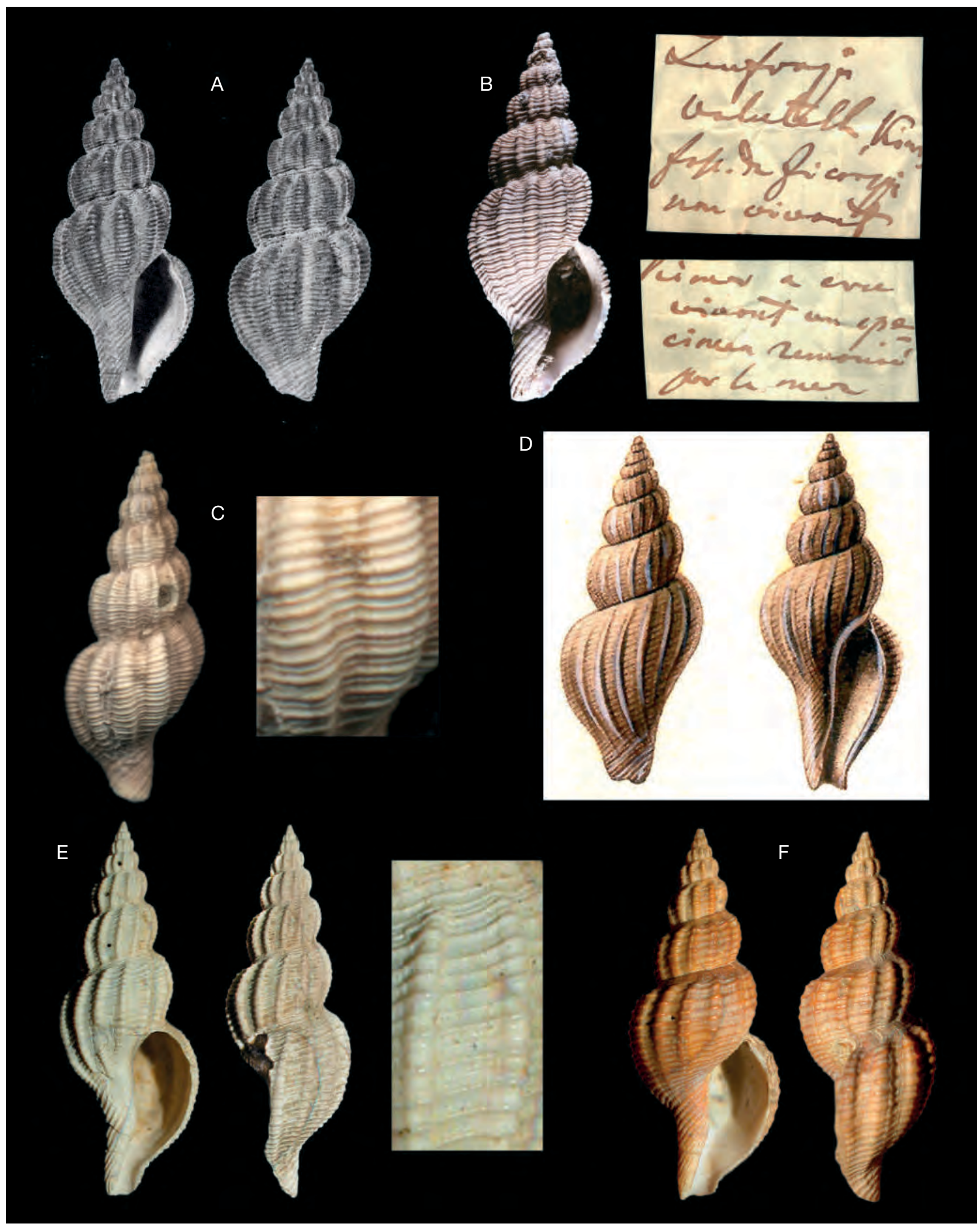

FIG. 21. - A, Pleurotoma inflata De Cristofori \& Jan, 1832, Lectotype, (MCSNM i4296) Tabiano (Parma) Piacentian (Pliocene), h. 15.3 mm (after Pinna \& Spezia, 1978, pl. 40); B, P. inflata, Ficarazzi (Palermo) (Lower Pleistocene), h. $18.9 \mathrm{~mm}$ (NMW, 12930), erroneously identified by Monterosato as Leufroyia volutella; C, $P$ inflata, Monte Pellegrino (Palermo) (Plio-Pleistocene) (MCZR-M-16706), h. 23.9 mm; D, Pleurotoma volutella Kiener, 1839, original drawings by Kiener, h. 25.4 mm; E, P. volutella, Ficarazzi (Palermo) (Lower Pleistocene), h. 21.5 mm; F, Pleurotoma cf. volutella Monte Pellegrino (Palermo) (Pliocene), h. 25.8 mm.

| 464

ZOOSYSTEMA $\cdot 2020 \cdot 42(22)$ 

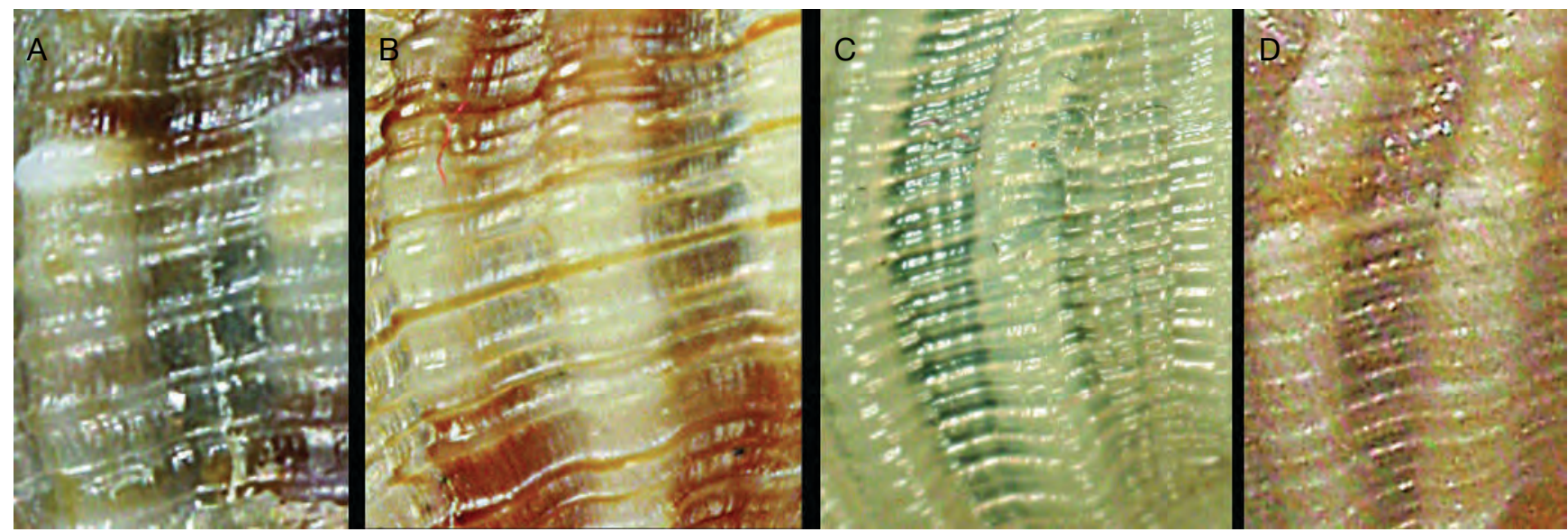

FIG. 22. - Details of spiral cordlets. A, L. leufroyi (Michaud, 1828), lle Rousse (Corse), h. 9.8 mm (coll. BAR); B, L. concinna (Scacchi, 1836$)$, Elba Island, 40 m, h. 14 mm (coll. BAR); C, L. erronea Monterosato, 1884, Bagni Fiume (Livorno), h. 16 mm (coll. PAG); D, L. villaria (Pusateri \& Giannuzzi-Savelli, 2008), Porto Cesareo (Taranto), 70 m, h. 14.2 mm (coll. PAG).

Spiral sculpture of 13-24 (mean 16.55, SD: 2.33) very narrow and low cords above the aperture, of which 3-4 very weak on narrow subsutural ramp, the most adapical cordlet well spaced from suture and often slightly stronger than other cordlets. Remaining cords equally strong and regularly spaced, often with a variable number of thinner cordlets between pairs of stronger ones; interspaces 3-5 times broader than cords; on first adapical whorl 5 thin spiral cords, the most adapical thinner than others.

Siphonal fasciole with 9-12 (mean 10.35, SD: 1.0) moderately strong, well spaced and slightly nodulose cords.

Cancellation rectangular, with elongate and only slightly elevated tubercles at the intersections.

Subsutural ramp narrow, subhorizontal on first whorls, concave and slightly inclined on lower ones, covered with dense growth marks of the anal sinus, crossed by 3-4 thin spiral cordlets.

Columella simple, straight medially and arcuate or angled posteriorly. Siphonal canal moderately long and wide, posterior canal deep and wide.

Outer lip thickened and smooth internally, with edge crenated by spiral cords.

Height of aperture: 4.3-7.03 mm (mean $5.92 \mathrm{~mm}$, SD: 0.96); A/H: 35.93-43.46\% (mean 39.61\%, SD: 2.21).

\section{Coloration}

Background colour variable but always light, from whitish to light brown, with areas, blotches and lines of different colour, occasionally uniformly coloured; first two teleoconch whorls often whitish. One cord (occasionally two) lighter than background, usually white-whitish, above suture, at approximately $1 / 3$ to $1 / 2$ of whorl height, the area above the cord usually slightly darker than the rest. Darker blotches and areas irregularly placed on axial ribs and interspaces on upper part of each whorl, often also below periphery and on siphonal fasciole and on subsutural ramps. Spiral cords occasionally of same colour as background, more often entirely or dashed brown or reddish-brown. Aperture internally white or beige, sometimes with light brownish blotches and lines visible by transparency.

\section{Soft parts}

Foot very long, broad and deeply bilobed anteriorly and with recurved anterolateral corners, narrowly tapering posteriorly. Siphon cylindrical with ventral slit, widely opening anteriorly, very extensile. Head small with a pair of long cylindrical tentacles, black eyes on bulges about halfway their length, distal part slightly longer and narrower than basal. Operculum absent.

Body translucent white with some parts yellowish or orange. Scattered white speckles on siphon, tentacles and upper side of foot. Posterior part of foot yellowish; tentacles translucent yellowish or pale orange; siphon pale yellowish in small specimens, orange in large ones (Fig. 19).

\section{REMARKS}

The foregut anatomy of a specimen from Malta, Qummick, $80 \mathrm{~m}$ depth (vi.1988, C. Mifsud leg; 15.5 x $6.1 \mathrm{~mm}$, protoconch tip missing, 1.5 protoconch whorls remaining, diagonally cancellate) was examined and described by Don Tippett (in litt., 2001). The specimen lacked a proboscis, poison apparatus, radula and salivary glands. The rhynchodaeum was very retracted and folded, with the posterior end bearing a tiny circular opening into the oesophagus.

This species is everywhere less common than the other 3 species of the genus. The first specimen of this species was submitted to our attention by Alberto Villari who identified it as Raphitoma volutella Kiener, 1839. With the same name, additional specimens were present in some other private collections. Kiener (1839: 67) described P. volutella as recent from Sicily, yet it is known that sometimes he reported the fossil species as living (Palazzi, unpublished ms.). In fact, Pleurotoma volutella is relatively well known from the Plio-Pleistocene (Seguenza 1880; Cerulli-Irelli 1910; Harmer 1915). Aradas \& Benoit (1876: 251) reported the finding of a fresh specimen of Pleurotoma volutella from Acitrezza. Unfortunately, a search in the Aradas collection at the Museo di Storia Naturale di Milano (merged into that of Priolo), was unsuccessful. This specimen must be considered lost as subsequently confirmed by Leonardi (MSNM, 
pers. com.). The type material of $P$. volutella has also not been found, despite a meticulous search in the Delessert collection studied by Kiener himself (Y. Finet, MHNG, pers. com.). The comparison with fossil specimens from Monte Pellegrino (Plio-Pleistocene) and Ficarazzi (Low Pliestocene) from the Monterosato collection and that of Melvill-Tomlin (NMW, 12930, given by Monterosato) showed that L. villaria and P. volutella are different species. This last specimen (Fig. 21B) is labelled by Monterosato "Leufroyia volutella Kiener, fossile di Ficarazzi, non vivente”. The second handwritten label reads: "Kiener a cru vivant un specimen ramassé par la mer". However, the specimens identified by Monterosato as "volutella" are quite different from each other and do not seem to be conspecific. The specimen (Fig. 21E) from Ficarazzi is the most similar to Kiener's drawings of $P$. volutella. According to Cipolla (1914: 73), Pleurotoma volutella falls within the chronological variation of Pleurotoma inflata De Cristofori \& Jan, 1832 whereas for Cerulli-Irelli (1910: 63 (255)) the two entities are separated. We are inclined to share the opinion of Cerulli-Irelli and believe that $P$. inflata and $P$. volutella are two different species (both known only as Plio-Pleistocene fossils, Fig. 21), and that both of them are different from L. villaria. L. villaria is distinguished from $L$. inflata by having:

1 - different outline (with less arched spire);

2 - axial ribs weaker (less high and wide), opistocline vs orthocline or slightly prosocline;

3 - much thinner and less dense spiral cords, and alternating cords and cordlets;

4 - interspaces between cords quite large vs very narrow;

5 - different opening shape (more oval vs more oblong);

6 - very short siphonal canal vs long one;

L. villaria is distinguished from $L$. volutella by having:

1 - more rounded outline;

2 - greater number of axial ribs which are flatter;

3 - more prominent, more numerous and less spaced spiral cords;

4 - different opening shape (more oval vs piriformis elongated);

5 - less wide and shorter siphonal canal.

The height and maximum diameter of protoconch depend on the number of whorls, in the photographed specimen (Fig. 20) with $\mathrm{PW}=3.04$ these two features are: $\mathrm{H}=735 \mu \mathrm{m}$ and max. $\mathrm{D}=593 \mu \mathrm{m}$. Diameter of nucleus and first whorl are quite large and similar to L. erronea, while in L. concinna and $L$. leufroyi these features are significantly smaller.

Maximum height of examined shells is $19 \mathrm{~mm}$, those larger than $20 \mathrm{~mm}$ are very rare. Mifsud (2003, as Raphitoma erronea) reported the maximum size of $25 \mathrm{~mm}$.

The original description was based on light and uniformly coloured specimens, but at least in the Adriatic and Aegean Sea they are usually brightly coloured, with brown or reddishbrown spiral cords and brown areas and blotches. Peńas et al. (2006: 126, figs 274-276 as Pleurotomella sp.) mentioned the presence of some brown cords also on the shells examined by them from Alboran Sea.

After a few years from collection the shells always look significantly different from the fresh ones, since the darker colours fade out and the shells become much lighter in colour, so even the shells with brown spiral cords often look almost uniformly coloured.

Diagnostic features of $L$. villaria from all other living Leufroyia spp. are: somewhat thinner and generally more slender shell, very thin spiral cords and narrow axial ribs, narrower subsutural ramps and more stepped whorls, medially the largest protoconch, differently coloured tentacles and foot of the animal.

Its identification is usually relatively easy, especially of large specimens, due to their slender shell and very thin spiral cords. Smaller specimens have less slender shell and can be confused with some untypical small shells of other species.

It differs from L. concinna, which also have brown spiral cords, by absence of pinkish/purple areas on the teleoconch, by thinner spiral cords and much larger protoconch, also by much bigger maximum size of shell.

L. leufroyi sometimes has similar colour pattern of shell (Fig. $5 \mathrm{H}$ ) to some colour forms of L. villaria, but even in such cases they can easily be differentiated by several features: small and dark $v$ s large and light protoconch, wide and less spaced $v s$ very thin and well spaced spiral cords; none or only one brown cord on each whorl $v$ s often almost all.

L. erronea has much lower H/W ratio; wider aperture; shorter siphonal canal; much stronger thickening of outher lip; stronger, denser and never brown coloured spiral cords.

\section{Acknowledgements}

We thank all colleagues who have made the material of their collections available to us for study. The following colleagues are heartily thanked for their help with museum samples under their care: Kemal Geyran (coll. CGS); Massimo Appolloni, Claudio Manicastri, Bruno Cignini, Giancarlo Babusci (MCZR); Cédric Audibert (MDCL); Philippe Bouchet, Virginie Héros, Pierre Lozouet, Philippe Maestrati, Manuel Caballer Gutierrez (MHNH); Yves Finet (MHNG); Jennifer Gallichan, Anna Holmes, Alison Trew (NMW); Henk Mienis (HUJ); Jerry Harasewych, Yolanda Villacampa (USNM); Anders Warén (SMNH). Special thanks to Giano Della Bella, Sergio Duraccio, André Hoarau, Attilio Pagli, Carlo Smriglio, Constantin Mifsud, Gianni Repetto, Paolo Russo, José Templado Gonzalez, Marielva Torino for their kind collaboration, and to Roberto Ardovini, Cédric Audibert, Enzo Campani, Christiane Delongueville, Alessandro Falleni, David Fenwick, Dominique Horst, Costas Kontadakis, Javier Martin, Bilal Oztürk, Alen Petani, Ignazio Sparacio, Peter Stahlschmidt, Morena Tisselli, Pero Ugarković, Jolanda Villacampa, for the photographs to provided. Two reviewers provided very valuable comments and criticisms to this ms. This work was partly supported by "Associazione Naturama” (Palermo).

\section{REFERENCES}

Albergoni A. \& Spada G. 1969. — Conchiglie del basso salernitano. Conchiglie 5: 155-163.

ADAMS H. \& ADAMS A. 1853 [1853-1858]. - The genera of recent Mollusca; arranged according to their organization. Vol. 1. John 
Van Voorst, London [Published in parts: Vol. 1:1-256, pls. 1-32, 1853; Vol. 1:257-484, 1854; Vol. 2:1-284, pls. 33-96, 1855 Vol. 2:285-412, pls. 97-112, 1856; Vol. 2:413-540, pls. 113128, 1857, Vol. 2:541-660, pls. 129-138, 1858]. https://doi. org/10.5962/bhl.title.4772

Alfaro M. E. \& Holder M. T. 2006. - The posterior and the prior in Bayesian phylogenetics. Annual Review of Ecology Evolution and Systematics 37: 19-42. https://doi.org/10.1146/annurev. ecolsys.37.091305.110021

Alberici E. \& TAMINI E. 1935. - Contributo allo studio de molluschi del Quaternario marino di Rodi (Egeo). Rendicont Reale Istituto Lombardo di Scienze e Lettere serie 2, 68: 213 228, pl. 3 .

Appolloni M., Smriglio C., Amati B., Lugliè L., Nofroni I., Tringali L. P., Mariottini P. \& Oliverio M. 2018. - Catalogue of the primary types of marine molluscan taxa described by T. A. di Maria, Marquis of Monterosato, deposited in the Museo Civico di Zoologia, Roma. Zootaxa, 4477 (1), 1-138. https://doi.org/10.11646/zootaxa.4477.1.1

Appelius F. L. 1869. — Le conchiglie del Mar Tirreno. Bullettino Malacologico Italiano 2: 124-141, pl. 4.

ARADAS A. \& BENOIT L. 1876 [1872-76]. — Conchigliologia vivente marina della Sicilia e delle isole che la circondano. Atti Accademia Gioenia Scienze Naturali 3 (6): 1-113 [1872]; 114-226 [1874]; 227-324 [1876], 5 pls. https://doi.org/10.5962/bhl.title.11386

Ardovini R. \& Cossignani T. 2004. - West African Seashells. L'Informatore Piceno, Ancona, 319 p.

ARduino G., Locatelli B., Orlando F. \& RepetTo G. 1995. Catalogo illustrato delle conchiglie marine del Mediterraneo. Associazione Amici del Museo "Federico Eusebio", Alba, 197 p.

Avila S. P., Azevedo J. M. N., GonçAlves J. M., Fontes J. \& CARDigOS F. 2000. - Checklist of the shallow-water marine molluscs of the Azores: 2, - São Miguel Island. Açoreana 9 (2): 139-173.

BAŁUK W. 2003. - Middle Miocene (Badenian) gastropods from Korytnica, Poland, 4. Turridae. Acta Geologica Polonica 53: 29-78. https://geojournals.pgi.gov.pl/agp/article/view/9720/8257

BARASH A. \& DANIN Z. 1992. - Annotated list of Mediterranean molluscs of Israel and Sinai. Israel Academy of Sciences and Humanities, Jerusalem, 405 p.

BASSO D. \& BRUSONI F. 2004. - The molluscan assemblage of a transitional environment the Mediterranean maërl from off the Elba Island (Tuscan Archipelago, Tyrrhenian Sea). Bollettino Malacologico 40 (1-4). 37-45.

Bellardi L. 1847. - Monografia delle Pleurotome Fossili del Piemonte. Stamperia Reale, Torino, 122 p., 4 pls. Published also in 1848 in the Memorie della Reale Accademia delle Scienze di Torino serie 2, t. 9: 531-650, 4 pls. https://doi.org/10.5962/bhl.title.58977

BELLARDI L. 1877. - I molluschi dei terreni terziarii del Piemonte e della Liguria. Parte II. Memorie della Reale Accademia delle Scienze di Torino serie 2, t. 29: 1-373. https://doi.org/10.5962/ bhl.title.12269

BeLLINI R. 1929. - I molluschi del Golfo di Napoli (Studi precedenti, l'ambiente, enumerazione e sinonimia). Annali Museo Zoologico Regia Università Napoli, 6: 1-87.

Berardelli B., Cosenza M., Cuomo M., Facente A., Fasulo G., IzZillo F., Perna E., Toscano F. \& Villani G. 1982. - Malacofauna marina della Campania - Area 042. Bollettino Malacologico 18 (9-12): 329-331.

Bertolaso L. \& PalazZi S. 2000. - Note sulla raccolta Seguenza di molluschi plio-pleistocenici della Provincia di Messina presso il Museo di Geologia e Paleontologia dell'Università di Firenze. Bollettino Malacologico 35 (1-4): 3-44.

Biagi V. \& Corselli C. 1978. - Contributo alla conoscenza della malacofauna di un fondo S.G.C.F. (Pérès-Picard, 1964). Conchiglie 14: 1-22.

Bogi C., Coppini M. \& Margelli A. 1980. - Contributo alla conoscenza della malacofauna del Tirreno Centrale Turridae: parte IV (1). La Conchiglia, 12 (136-137): 14-15.
Bogi C. 1986. - Prima segnalazione di Pleurotomella demosia (Dautzenberg \& Fischer, 1896) in mar Mediterraneo. Notiziario C.I.S.Ma. 7-8: 27-28.

Bogi C. \& Cauli L. 1998. — La malacofauna circalitorale del Pliocene Medio di Casa Pagliana (Fauglia-Pisa). Bollettino Malacologico 33 (9-12): 127-134.

BORJA A. \& MuXIKA I. 2001. - Actualizacion del catálogo de los moluscos marinos de la costa vasca en campañas realizadas por AZTI. Iberus 19 (2): 67-85. https://archive.org/details/biostor- $133349 /$ mode/1up

BORJA A. 1987. - Catálogo de los moluscos marinos de la costa vasca. Iberus 7 (2): 211-223. https://archive.org/details/biostor-133503

Bouchet P., Kantor Yu. I., Sysoev A. \& Puillandre N. 2011. A new operational classification of the Conoidea (Gastropoda). Journal of Molluscan Studies, 77 (3): 273-308.

BOYER F. \& D'AUDIBERT C. 2007. - Le matériel d'auteur conservé au Muséum de Lyon pour les taxa de Michaud, 1828 et 1829. Cahiers scientifiques - Département du Rhône - Musée des Confluences, Lyon 13: 149-159.

BRÉBION P. 1964. — Les gastéropodes du Redonien et leur signification, 1-2. Thèse de doctoratès-Sciences. Faculté des Sciences de l'Université de Paris, 775 p., 15 pls. (27 June 1964, unpublished).

BROOKES KNIGHT J. 1941. - Paleozoic Gastropod Genotypes. Geological Society of America 32: 1-510. https://doi.org/10.1130/SPE32

Brown S. F. J., Collins R. A., Lefort M. C., MalumbresOlarte J., Vink C. J. \& Cruickshank R. H. 2012. — Spider: An $\mathrm{R}$ package for the analysis of species identity and evolution, with particular reference to DNA barcoding. Molecular Ecology Resources, First published:16 January 2012. https://doi. org/10.1111/j.1755-0998.2011.03108.x

BROWN T. 1844. - Illustrations of the Recent conchology of Great Britain and Ireland, with the description and localities of all the species, marine, land, and fresh water. Drawn and coloured from nature, second edition, greatly enlarged. Smith, Elder \& Co., London, XIII, 144 p., 59 pls. https://www.biodiversitylibrary. org/page/10921172

BrugnONe G. A. 1862. - Memoria Sopra Alcuni Pleurotomi Fossili dei Dintorni di Palermo. F. Lao, Palermo, 41 p., 1 pl.

BrunetTi M. M. \& Della Bella G. 2006. - Leufroyia ferrierii: una nuova specie per il Pliocene Toscano. Bollettino Malacologico, 42 (9-12): 118-120.

BRUnetTi M. M. \& VeCCHI G. 2005. - Nuove specie di Gasteropodi del Piacenziano del rio Crevalese, Castell'Arquato (Piacenza, Italia). Bollettino Malacologico, 41, (1-4): 1-22.

BRUSinA S. 1866. - Contribuzione pella fauna dei Molluschi dalmati. Verhandlungen der Kaiserlich-königlichen zoologischbotanischen Gesellschaft in Wien, 16, 1-134, 1 pl. http://www. biodiversitylibrary.org/item/41695

Brusina S. 1870. - Ipsa Chiereghinii Conchylia, ovvero contribuzione pella Malacologia Adriatica desunta dal manoscritto "Descrizione de 'Crostacei, de' Testacei, e de' Pesci che abitano le Lagune e Golfo Veneto, rappresentati in figure, a chiaro-scuro ed a colori dall' Abate Stefano Chiereghini ven. Clodiense". Editori della Biblioteca Malacologica, Pisa, 280 p. https://doi.org/10.5962/ bhl.title. 118554

Bucquoy E., Dautzenberg P. \& Dollfuss G. 1883. - Les mollusques marins de Roussillon. Tome I: Gastropodes. J.-B. Baillière \& Fils, Paris, 570 p., 66 pls. [Turrids are in fascicule 1 (3): 85-135, pls. 11-15]. https://gallica.bnf.fr/ark:/12148/bpt6k6215119z

CACHIA C. 1999. - Il-Molluski ta Malta. Malta, Pubblikazzjonijiet Indipendenza Kullana Kulturali no. 5, x, 210 p.

Cachia C., Mifsud C. \& Sammut P. M. 1993. - An Annotated Check-List of the Marine Mollusca of the Maltese Islands. Erste Vorarlberger Malakologische Gesellschaft, Rankweil, Austria, 81 p. Cachia C., Mifsud C. \& Sammut P. M. 2001. - The Marine Mollusca of the Maltese Islands. Part 3: Sub-Class Prosobranchia to Sub-Class Pulmonata, Order Basommatophora. Backhuys Publishers, Leiden, $266 \mathrm{p}$. 
Cachia C., Mifsud C. \& Sammut P. M. 2004. - The Marine Mollusca of the Maltese Islands. Part 4: The Classes Caudofoveata, Solenogastres, Bivalvia, Scaphopoda and Cephalopoda. Backhuys Publishers, Leiden, 270 p.

CADÉE G. C. 1968. - Molluscan biocoenoses and thanatocoenoses in the Ria de Arosa, Galicia, Spain. Zoologische Verhandelingen. 95: 1-121, pl. 1-6.

Calcara P. 1839a. - Ricerche Malacologiche. G. Pedone, Palermo, 16 p.

CAlCARA P. 1839b. - Esposizione di alcune nuove specie di Conchiglie appartenenti al Genere Pleurotoma del Sig. De Lamarck fatta dal Dr. Pietro Calcara, coll'aggiunta di tutte le altre fossili e viventi, che rinvengonsi nei dintorni di Palermo. L'Oreteo 3: 17-18, part 1; 4: 25-26 part 2.

CAPELLINI G. 1860. — Sui testacei marini della costa del Piemonte per J. Gwyn Jeffreys. Traduzione con note ed un catalogo speciale per il golfo della Spezia. Regio Istituto de' Sordo-Muti, Genova, 67 p., 1 pl.

CARUANA A. 1867. - Enumeratio ordinata molluscorum Gaulo-Melitensium of the late Mr. Giuseppe Mamo. British Press, Malta, 78 p. https://doi.org/10.5962/bhl.title.13191

Caruana-Gatto A. \& Despott G. 1919. - Materiale per una malacofauna marina delle isole Maltesi. Empire Press, Malta, 27 p. [Published also in Archivium Melitense 3 (8-12): 431-444; 4 (1): 38-46].

CARUS J. V. 1893. - Prodromus faunae Mediterraneae sive descriptio animalium Maris Mediterranei incolarum quam comparata silva rerum quatenus innotuit adiectis locis et nominibus vulgaribus. Vol. 2: Brachiostomata. Mollusca. Tunicata. Vertebrata. E. Schweizerbart'sche. Stuttgart, ix, 854 p.

Cavallo O. \& RepetTo G. 1992. - Conchiglie fossili del Roero Atlante iconografico. Associazione Naturalistica Piemontese Memorie 2: 1-251.

Cecalupo A., Buzzurro G. \& Mariani M. 2008. - Contributo alla conoscenza della malacofauna del Golfo di Gabès (Tunisia). Quaderni della Civica Stazione Idrobiologica di Milano 31: 1-175, 91 pls.

Cerulli-Irelli S. 1910. - Fauna Malacologica Mariana Parte Quarta. Scaphopoda: Dentalidae. Gastropoda: Stenogyridae, Gadiuiidae, Acteonidae, Tortnatinidae, Scaphandridae, Bullidae, Ringiculidae, Philinidae, Umbrellidae, Conidae, Pleurotomidae. Palaeontographia Italica 16: 23-70, pls. 3 (34) - 6 (37).

Ceulemans L., Van Dingenen F., Bernard M. \& LANDAU B.M. 2018. - The lower Pliocene gastropods of Le Pigeon Blanc (Loire-Atlantique, northwest France). Part. 5: Neogastropoda (Conoidea) and Heterobranchia (fine). Cainozoic Research 18 (2): 89-176.

Chester C., Agosti D., Sautter G., Catapano T., Martens K., GÉRARD I. \& BÉNICHOU L. 2019. - EJT editorial standard for the semantic enhancement of specimen data in taxonomy literature. European Journal of Taxonomy 586: 1-22. https://doi. org/10.5852/ejt.2019.586

CHIRLI C. 1997. - Malacofauna pliocenica toscana. Vol. 1. B.M.B., Firenze, 129 p., 29 pls.

Cipolla F. 1914. - Le Pleurotomidi del pliocene di Altavilla (Palermo). Palaeontographia Italica, Memorie di palentologia, 20: 105 (1)-181 (77), pls. 12 (1)-14 (3).

Claudon E. 1902. - Faunule malacologique marine de SaintRaphael (Var). La feuille des jeunes naturalistes: revue mensuelle d'histoire naturelle 32: 184-199.

CoCCONI G. 1873. - Enumerazione sistematica dei molluschi miocenici e pliocenici delle provincie di Parma e di Piacenza. Memoire della Accademia delle Scienze dell'Instuto di Bologna serie 3 3: 409-776, 11 pls.

Coen G. S. 1933. - Saggio di una Sylloge Molluscorum Adriaticorum. Memorie Comitato Talassografico Italiano 192: VII+186, $10 \mathrm{pls.}$

Compagnoni B., Conato V., Follieri M. \& Malatesta A. 1969. Il Quaternario di Scalea. Quaternaria 10: 95-123.

Consolado Macedo M. C. 1996. - Rei Dom Carlos: Campanhas oceanográphicas. Estudo das colleçôes malacológicas. Ediçôes INAPA, Lisboa, 191 p.
Coppi F. 1869. - Catalogo dei fossili miocenici e pliocenici del modenese. Annuario della Società dei Naturalisti 4: 163-228.

Corselli C. 1981. — La tanatocenosi di un fondo S.G.C.F. Bollettino Malacologico 17: 1-26.

Cossignani T. \& ARdovini R. 2011. - Malacologia Mediterranea. L'Informatore Piceno, Ancona, $536 \mathrm{p}$.

Cossignani T., Cossignani V., Di Nisio A. \& Passamonti M. 1992. - Atlante delle conchiglie del Medio Adriatico. L'Informatore Piceno, Ancona, $120 \mathrm{p}$.

Cossmann M. 1896. - Essais de Paléoconchologie Comparée. Vol. 2. Cossmann, Paris, 180 p., 8 pls.

Costa O. G. 1844. - Catalogo de'testacei viventi del piccolo e grande mare di Taranto redatto sul sistema di Lamarck. Atti Reale Accademia di Scienze in Napoli 5 (2): 13-66, 4 pls.

Cretella M., Crovato C., Crovato P., Fasulo G. \& Toscano F. 2005. - The malacological works of Arcangelo Scacchi (18101893). Part II: A critical review of Scacchian taxa. Bollettino Malacologico 40 (9-12): 114-131.

Crocetta F. \& Spanu M. 2008. - Molluscs associated with a Sardinian deep water population of Corallium rubrum (Linnt, 1758). Mediterranean Marine Science 9(2): 63-86. https://doi. org $/ 10.12681 / \mathrm{mms} .133$

CROSSE H. 1885. - Nomenclature generica e specifica di alcune Conchiglie Mediterranee, pel marchese di Monterosato. Journal de Conchyliologie, 33: 139-142. http://biodiversitylibrary.org/ page/15979493

D’Angelo G. \& GARgiullo S. 1978. — Guida alle conchiglie mediterranee. Conoscerle, cercarle, collezionarle. Milano, Fabbri Editore, $224 \mathrm{p}$.

D’Orbigny A. 1852. - Prodrome de paléontologie stratigraphique universelle des animaux mollusques \& rayonnés, faisant suite au Cours élémentaire de paléontologie et de géologie stratigraphiques. Vol. 3. V. Masson, Paris, 191 p. https://gallica.bnf.fr/ark:/12148/ bpt6k291611

DautZenberg P. 1889. - Contribution à la faune malacologique des Iles Açores. Résultats des Campagnes Scientifiques Accomplies sur son Yacht par Albert Ier Prince Souverain de Monaco 1: 1-112, 4 pls. https://doi.org/10.5962/bhl.title.13198

DAUTZENBERG P. 1891. - Contribution à la faune malacologique du Golfe de Gascogne. Mémoires de la Société Zoologique de France 4: 604-619, 2 pls. https://gallica.bnf.fr/ark:/12148/bpt6k4326278

De CASA G. \& Hallgass A. 1979. - Osservazioni sul sottogenere Leufroyia del genere Raphitoma. Notiziario CISMA 1 (1): 5-14.

De CRISTOFORI J. \& JAN G. 1832. — Catalogus in quatuor sectiones divisus rerum naturalium in museo exstantium Josephi de Cristofori et Georgii Jan plurium Acad. Scient. et Societ. Nat. Cur. Sodalium complectens adumbrationem oryctognosiae et geognosiae atque prodrumum faunae et floriae Italiae Superioris. Sectio II. - Pars I. Carmignani, Parmæ, p. [1-7], [Conchylia] 1-8, [1], [Mantissa] 1-4, [Excerptum] 1-4, [1], [Conchylia fossilia] 1-16, [1-2]. https:// doi.org/10.5962/bhl.title.59812

De Lamothe L. J. B. \& Dautzenberg P. 1908. - Catalogue des Mollusques qu'ils renferment, p. 488-501, in de Lamothe, Les Gîtes fossiliferes des marnes plaisanciennes du Sahel d'Alger. Bulletin de la Société Géologique de France, série 4, tome 7: 481-505 [de Lamothe is listed as "Le Général de Lamothe »]. https://www. biodiversitylibrary.org/page/30560555

Delamotte M. \& Vardala-Theodorou E. 1994. - Koxv́d $l \alpha$

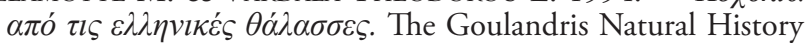
Museum, Kifissia, 317 p.

Delle Chiaje S. 1831 [1823-1831]. — Memorie sulla storia e gli animali senza vertebre del regno di Napoli. Fratelli Fernandes, Napoli (volume 1) and Società Tipografica, Napoli (volumes 2-4). Vol. 1, p. I-XII, 1-84 [1823], p. 1-184 [1824]; vol. 2, p. [1-4] + 185-224 [1825], p. 225-444 [1826]; vol. 3, p. I-XX, p. 1-232 [1828]; vol. 4, p. I-VII [1831], 1-116 [1830], p. 117-214 [1831]; pl. 1-4; pl. 1-69 [date?], Pl. 70-109 [1830]. https://doi. org/10.5962/bhl.title.10021 
Deshayes G. P. 1835. - Expédition scientifique de Morée. Bertrand, Paris. Vol. 3 (Mollusques): 81-203, Atlas, pls. 18-26.

DesPotT G. 1919. - The Mollusca of Marsascirocco Harbour Malta. Proceedings of the Malacological Society of London 13 (5-6): 168183. https://www.biodiversitylibrary.org/page/15771030

DEVIDTS J. 1959. - Mollusques marins recueillis à la Ciotat (B.-du-Rh.). Bulletin du Muséum National d'Histoire Naturelle de Marseille 19: 93-111.

Dewalque G. 1880. — Prodrome d'une Description Géologique de la Belgique, $2^{d}$ edition. H. Maceaux, Brussels, xi-501 p. https:// gallica.bnf.fr/ark:/12148/bpt6k96434881

Di Stefano G. 1889. - Il Pliocene e Postpliocene di Sciacca; osservazioni stratigrafiche. Bollettino Regio Comitato Geologico Italiano, ser. II 10 (3-4): 69-110. https://www.biodiversitylibrary. $\mathrm{org} /$ page $/ 53553460$

DODERLEIN P. 1864. - Cenni geologici intorno la giacitura dei terreni miocenici superiori nell'Italia centrale, in Atti del X Congresso degli scienziati italiani, Siena, 1862. Siena, 1864, 83-107.

Dollfus G. \& DAuTZENBerg P. 1886-1887. — Etude préliminaire des coquilles fossiles des faluns de la Touraine. La Feuille des Jeunes Naturalistes 16 (1886): 77-80, 92-96, 101-105, 138-143; 17 (1887): 33-36. http://gallica.bnf.fr/ark:/12148/bpt6k99075w

DOLLFUSS C. F. \& DAUTZENBERG P. 1886. — Étude préliminaire des coquilles fossiles des faluns de la Tourraine. La Feuille des Jeunes Naturalistes 16 (189): 101-105. http://gallica.bnf.fr/ ark:/12148/bpt6k99075w

Fassio G., Russini V., Pusateri F., GiannuZzi-Savelli R., Høisaeter T., Puillandre N., Modica M. V. \& Oliverio M. 2019. - An assessment of Raphitoma and allied genera (Neogastropoda: Raphitomidae). Journal of Molluscan Studies 85 (4): 414-425. https://doi.org/10.1093/mollus/eyz022

FISCHER P. 1878. — Essai sur la distribution géographique des brachiopodes et des mollusques du littoral océanique de la France. Actes de la Société Linnéenne de Bordeaux 33: 171-214.

Folmer O., Blac M., Hoeh W., Lutz R. \& Vrijenhoek R. 1994. DNA primers for amplification of mitochondrial cytochrome c oxidase subunit I from diverse metazoan invertebrates. Molecular Marine Biology and Biotechnology 3 (5): 294-299.

FORBES E. 1844. - Report on the Mollusca and Radiata of the Aegean Sea, and on their distribution, considered as bearing on geology. Reports of the British Association for the Advancement of Science for 1843 1843[1844]: 130-193. http://biodiversitylibrary.org/page/12920789

FORBES E. \& HANLEY S. 1853. - The families of Gasteropoda from Neritidae to Elysiadae. A history of British Mollusca, and their shells. Vol. 3. John Van Voorst, London: 321-616, pls. W, MM, AAA-SSS, 94E-133. [Lettered plates were not present in the examined copy.]. https://www.biodiversitylibrary.org/page/ 12891724

FORESTI L. 1874. - Catalogo dei molluschi fossili Pliocenici delle colline Bolognesi. Parte II (Conchiferi e Brachiopodi). Memorie della Accademia delle Scienze Dell'Istituto di Bologna, serie terza 4: 295-378, 1 pl.

FretTer V. \& GRAHAM A. 1985. - The prosobranch molluscs of Britain and Denmark. Part 8: Neogastropoda. Journal of Molluscan Studies supplement 15: 435-556.

FrIedBerG W. 1912 [1911-1928]. — Mięczaki mioceńskie ziem Polskich (Mollusca Miocaenica Poloniae), 1. Ślimaki i tódkonogi, 1. Gastropoda et Scaphopoda. Muzeum Imienia Dzieduszyckich, Lwow, 31 p. [issued in parts: 1, 1-112, pls 1-5 (1911); 2, 113 240, pls 6-14 (1912); 3, 241-360, pls 15-20 (1914); 4, 361-440, pls 21-26 (1923); 5, 441-631, pls 27-38 (1928). Reprinted 1951-55 with slightly different title and pagination, Warszawa (Wydawnictwa Geologiczne)].

FRIEDBERG W. 1951. — Mieczaki mioceńskie ziem polskich i krajów przylegtych (Mollusca Miocenica Poloniae et Regionum Vicinarum). (Pars 1. Gasteropoda). Polskie Towarzystwo Geologiczne, Kraków, 234 p., 14 pls.

GHISOTTI F. 1972. — Le conchiglie del golfo di Gabés (parte prima). Conchiglie 8: 63-89.
Giannuzzi-Savelli R., Pusateri F. \& Bartolini S. 2018a. A revision of the Mediterranean Raphitomidae (Gastropoda, Conoidea), 7: on the sibling species Raphitoma densa (Monterosato, 1884) and R. griseomaculata n. sp. Biodiversity Journal 9(4): 429440. https://doi.org/10.31396/Biodiv.Jour.2018.9.4.429.440

Giannuzzi-Savelli R., Pusateri F. \& Bartolini S. 2018b. A revision of the Mediterranean Raphitomidae (Gastropoda Conoidea), 5: Loss of planktotrophy and pairs of species, with the description of four new species. Bollettino Malacologico, 54 Suppl. 11: 1-77

GiannuZZi-Savelli R., Pusateri F., Bartolini S. \& Oliverio M. 2017. A revision of the Mediterranean Raphitomidae (Neogastropoda Conoidea) 4: The species of the group of Raphitoma purpurea (Montagu, 1803) with the description of a new species. Bollettino Malacologico 53: 161-183

Gignoux M. 1913. — Les formations marines Pliocénes et Quaternaires de l'Italie du Sud et de la Sicile. Annales Université de Lyon 36: 1-639, 21 pls.

Giribet G. \& PeÑAs A. 1997. - Fauna malacológica del litoral del Garraf (NE de la Península Ibérica). Iberus 15 (1): 41-93.

Glibert M. 1954. - Pleurotomes du Miocène de la Belgique et du Bassin de la Loire. Mémoires de l'Institut Royal des Sciences Naturelles de Belgique 129: 1-75.

GliberT M. 1960. — Gastropodes du Diestien, du Scaldisien et du Merxemien de la Belgique. 4e Note (Fin). Annexe. Additions aux Pleurotomes du Neogène du Bassin de la Loire (France). Bulletin Institut Royal des Sciences Naturelles de Belgique 36 (33): 1-44, pls. 4-5.

Gofas S., Moreno D. \& Salas C. 2011. - Moluscos marinos de Andalucia - I. University of Malaga, Malaga, $342 \mathrm{p}$.

GRAHAM A. 1988. - Molluscs: prosobranch and pyramidellid gastropods. In Kermack D.M. \& Barnes R.S.K. (Eds.) Synopsis of the British Fauna (New Series). No. 2 (Second Edition). E.J. Brill/ Dr. W. Backhuys for the Linnean Society of London and the Estuarine and Brackish-Water Sciences Association, Leiden, New York, København and Köln, p. vii + 652 .

Harmer F. W. 1915. - The Pliocene Mollusca of Great Britain being supplementary to S. V. Wood's Monograph of the Crag Mollusca. Part II. Monograph of the Palaeontological Society of London 68: 201302, pls 25-32. https://doi.org/10.1080/02693445.1915.12035571

HaYWard P. J., Wigham G. D. \& YonOW N. 1995. — Molluscs (Phylum Mollusca). In Hayward, P.J. \& Ryland, J.S. (Eds.) Handbook of the Marine Fauna of North-West Europe. Oxford University Press, Oxford, p. 484-628.

Hillis D. \& BULL J. J. 1993. An empirical test of bootstrapping as a method for assessing confidence in phylogenetic analysis. Systematic Biology 42: 182-192. https://doi.org/10.1093/sysbio/42.2.182

HøISAETER T. 2016. - A taxonomic review of the Norwegian species of Raphitoma (Gastropoda: Conoidea: Raphitomidae). Fauna Norvegica 36: 9-32. https://doi.org/10.5324/fn.v36i0.1839

HÖRNES M. 1854 [1851-1870]. — Die fossilen Mollusken des Tertiär-Beckens von Wien. Abhandlungen der K. K. Geologischen Reichsanstalt 3: 1-42, pl. i-v (1851), 43-208, pl. vi-xx (1852), 209-296, pl. xxi-xxxii (1853), 297-382, pl. xxxiii-xl (1854), 383-460, pl. xli-xlv (1855), 461-736, pl. xlvi-lii (1856); 4: 1479, pl. i-lxxxv (1870).

HUBENDICK B. \& WARÉN A. 1974. - Småsnackor vid svenska västkusten 6: Släktena Emarginula, Lacuna, Natica, Philbertia, Lora. Särtryck ur Göteborges Naturhistoriska Museum, Arstryck 1974, p. 25-32.

IDATO E., Fresi E. \& RuSSO G. F. 1983. — Zonazione verticale della fauna vagile di strato foliare di una prateria di Posidonia oceanica Delile. Bollettino Malacologico 19 (5-8): 109-120.

JefrReys J. G. 1856. - On the marine Testacea of the Piedmontese coast. Annals and Magazine of Natural History, series 2 17: 155188. http://biodiversitylibrary.org/page/22069750

JEFFREYS J. G. 1859. - Additional gleanings in British conchology. Annals and Magazine of Natural History, series 34: 189-201. 
JefFreys J. G. 1867. — British Conchology, or an account of the Mollusca which now inhabit the British Isles and surrounding seas. Vol. 4. John Van Voorst, London, 486 p., 8 pls. [plates published in 1869 as part of Vol. 5]. https://www.biodiversitylibrary.org/ page/ 16363027

JEFFREYS J. G. 1870. - Mediterranean Mollusca part V. Annals and Magazine of Natural History, series 34 (6): 65-86.

JefFreYs J. G. 1882. - Notes of the Mollusca procured by the Italian exploration of the Mediterranean in 1881. Annals and Magazine of Natural History, ser. 5 10: 27-35. https://www.biodiversitylibrary.org/page/51244023

KANTOR YU I. \& TAYLOR J. D. 2002. - Foregut anatomy and relationships of raphitomine gastropods (Gastropoda: Conoidea: Raphitominae), In Oliverio M. \& Chemello R. (eds), Systematics, Phylogeny and Biology of the Neogastropoda. Bollettino Malacologico Supplement 5: 161-174.

KATOH K., ROZEWICKI J. \& YAMADA K. D. 2017. — MAFFT online service: multiple sequence alignment, interactive sequence choice and visualization. Briefings in Bioinformatics bbx108. https://doi. org/10.1093/bib/bbx108

Kearse M., Moir R., Wilson A., Stones-Havas S., Cheung M., Sturrock S., Buxton S., CoOper A., Markowitz S., Duran C., Thierer T., Ashton B., Meintjes P. \& Drummond A. 2012. Geneious Basic: an integrated and extendable desktop software platform for the organization and analysis of sequence data. Bioinformatics 28 (12): 1647-1649. https://doi.org/10.1093/bioinformatics/bts199

Kiener L. C. 1839. - Genre Pleurotome. (Pleurotoma, Lam.) Spécies général et iconographie des coquilles vivantes comprenant la collection du Muséum d'Histoire naturelle de Paris, collection Lamarck, celle du Prince Masséna et les découverts récente des voyageurs. Vol. 5. Rousseau, Paris, 84 p., 27 pls. https://doi.org/10.5962/bhl.title.39135

KLEĆAK B. 1873. - Catalogus ad rationem synonymion ordinatus marinorum molluscorum Dalmatiae, qua ut inter opera artificiaque propalara collocanda ponerentur anno 1873 Vindobonam mittit Blasius Klecak. Typis Antonii Zannoni, Spalati, 44 p.

KNUDSEN J. 1952. - Marine prosobranchs of tropical West Africa collected by the Atlantide Expedition, 1945-46. Videnskabelige Meddelelser fra Dansk Naturhistorisk Forening i Kjobenhavn 114: 129-185, 3 pls.

KNUDSEN J. 1956. - Remarks on a collection of marine prosobranchs from Senegal. Bulletin Institute Française de l'A Arique Noir, 18 ser. A n. 2: 514-529 (april).

KobeLT W. 1905 [1904-1905]. — Iconographie der schalentragenden europäischen Meeresconchylien. Vol. 3. C.W. Kreidel, Wiesbaden, 219-406 p., pls. 79-98. [219-272 p., pls. 79-84, 86, \& $87=1904$ 273-406 p., pls. $85,88-98$ p. $=1905$; dates and pagination from Aarsten et al., 1984]. http://www.biodiversitylibrary.org/item/40977

Koutsoubas D., Koukouras A., Karakassis I. \& Dounas C. 1992. - Contribution to the knowledge of Gastropoda and Bivalvia (Mollusca) of Crete Island (S. Aegean Sea). Bollettino Malacologico 28 (1-4): 69-82.

Kumar S., STecher G. \& TAMura K. 2016. - MEGA7: Molecular Evolutionary Genetics Analysis Version 7.0 for Bigger Datasets. Molecular Biology and Evolution 33 (7): 1870-1874 (July 2016). https://doi.org/10.1093/molbev/msw05

Kuraku S., ZMaseK C. M., Nishimura O. \& Katoh K. 2013. aLeaves facilitates on-demand exploration of metazoan gene family trees on MAFFT sequence alignment server with enhanced interactivity. Nucleic Acids Research 41: W22-W28. https://doi. org/10.1093/nar/gkt389

Landau B. M., HarZHauser M., YeȘim İsLamoĞLu Y. \& MarQueS DA SILVA C. 2003. - Systematics and palaeobiogeography of the gastropods of the middle Miocene (Serravallian) Karaman Basin, Turkey. Cainozoic Research 11-13: 3-584, 69 pls.

Landau B. M., Van Dingenen F. \& Ceulemans L. 2020. - The upper Miocene gastropods of northwestern France, 5. Conoidea. Cainozoic Research 20 (1): 3-107. https://doi.org/10.11646/ zootaxa.4447.1.1
Lebour M. V. 1934. - The eggs and larvae of some British Turridae. Journal of the Marine Biological Association of the United Kingdom, N. F. 19 (2): 541-553.

Leray M., Yang J. Y., Meyer C. P., Mills S. C., Agudelo N., Ranwez V., BOeHM J. T., Machida R. J. 2013. - A new versatile primer set targeting a short fragment of the mitochondrial COI region for metabarcoding metazoan diversity: application for characterizing coral reef fish gut contents. Frontiers in Zoology 10: no. 34. https://doi.org/10.1186/1742-9994-10-34

LOCARD A. 1886. - Prodrome de malacologie Française Mollusques marins. Annales de la Société d'Agriculture et d'Histoire Naturelle de Lyon, série 5, 8: 1-216 [Continued in Vol. 9: 1-320, 1886.].

LOCARD A. 1891. - Contribution à la faune malacologique française XVI. Les coquilles marines vivantes de la faune française décrites par G. Michaud. Etudes critiques d'aprés les types de ses collections. Annales de la Societé d'Agriculture, Histoire et Arts utiles de Lyon, Ge série 3[1890]: 93-134. https://gallica.bnf.fr/ ark:/12148/bpt6k54370051

LOCARD A. 1892. - Les coquilles marines des côtes de France. J.-B. Baillière et Fils, Paris, 384 p.

LOCARD A. 1899. - Conchyliologie française. Les coquilles marines au large des côtes de France, faune pélagique et faune abyssale, description des familles, genres et espèces. Baillière, Paris, 198 p. https://gallica.bnf.fr/ark:/12148/bpt6k6315113q

LOCARD A. \& CAZIOT E. 1899. - Les coquilles marines des côtes de Corse. Annales de la Société Linnéenne, Lyon 46 : 193-274. [A reprint of this work was published as separate book with the same title in 1900 by J.B. Baillière et fils, Paris]. https://gallica. bnf.fr/ark:/12148/bpt6k9910/z/f2.image

LOZET J. B. \& DejEAN-ARRECGROS J. 1977. - Je Découvre les Coquillages Côtes Européennes et Méditerranéennes. André Leson, Paris, 174 p.

LuQue del Villar A. \& Templado Gonzalez J. 1981. — Estudio de una tanatocenosis de moluscos de la isla de sa Torreta (Formentera). Iberus 1: 23-32. https://www.biodiversitylibrary. org/page/32802399

MALM A. W., 1855. - Malakozoologiska bidrag, till Skandinavisk Fauna. Götheborgs Kongliga Vetenskaps och Vitterhets Samhâlles Handlingar 3: 1-48, 1 pl.

Manousis T. 2012. - The sea shells of Greece. Kyriakidis Brothers S.A., Thessaloniki, $381 \mathrm{p}$.

Manousis T., Kontadakis C., Mbazios G. \& Polyzoulis G. 2018. - The family Raphitomidae (Mollusca: Gastropoda: Conoidea) in the Greek Seas with the description of two new species. Journal of Biological Reasearch - Thessaloniki 25: article no. 14. https://doi.org/10.1186/s40709-018-0085-3

MARQUET R. 1998. - The Pliocene turrid gastropods of Belgium, 2. Conidae (genera Asthenotoma, Comarmondia, Cytharella, Mangelia, Lusitanops, Raphitoma and Philbertia). Bulletin de l'Institut Royal des Sciences Naturelles de Belgique, Sciences de la Terre 68: 263-287.

MARS P. 1956. - Faunes malacologiques du Pliocène et du Quaternaire dee Milazzo (Sicile). Bulletin Musée Histoire Naturelle Marseille 16: 33.52.

Marshall J. T. 1912. — Additions to 'British Conchology'. Journal of Conchology 13: 294-306.

Martini N., Gillone G., Lombardi C. \& Sabelli B. 2001. Mollusc community of a Posidonia oceanica (L.) Delile bed: Annual variability. Bollettino Malacologico 36 (9-12): 191-194.

Mazziotti C., Agamennone F. \& Tisselli M. 2008. - Checklist della malacofauna delle Isole Tremiti (Medio Adriatico). Bollettino Malacologico 44 (5-8): 71-86.

MCMilLan N. 1973. — British shells. Warne Co., London, 195 p., 80 pls.

MEZNERICS I. 1933. - Die Minutien der tortonischen Ablagerungen von Steinabrunn in Niederösterreich. Annalen des Naturhistorischen Museums in Wien 46: 319-359, pls. 13-14.

Michaud A. L. G. 1828. - Description de plusieurs espèces de coquilles vivantes de la Méditerranée. Bulletin d'Histoire Naturelle de la Société Linnéenne de Bordeaux 2(10): 119-122, 1 pl. http://biodiversitylibrary.org/page/35729992 
Mifsud C. 1993. - Notes on some Mollusca from Maltese waters. La Conchiglia 24 (265): 4-9.

Mifsud C. 2003. - Note su alcuni molluschi viventi da Malta. La Conchiglia 307: 39-46.

Montefameglio L., Pavia G. \& Rosa D. A. 1979. — Associazioni a molluschi del Tabianiano del Basso Monferrato (Alba, Italia NW). Bollettino della Società Paleontologica Italiana 18: 173-199.

Monterosato T. A. (di) 1872. - Notizie Intorno alle Conchiglie Mediterranee. Michele Amenta, Palermo, 61 p. http://biodiversitylibrary.org/page/34578233

Monterosato T. A. 1874. - Recherches Conchyliologiques effectuées au cap Santo Vito, en Sicile. Journal de Conchyliologie 22 (3): 243-282. http://biodiversitylibrary.org/page/15661963

MONTEROSATO T. A. 1875. - Nuova rivista delle conchiglie mediterranee. Atti dell'Accademia di Scienze, Lettere ed Arti di Palermo, nuova serie 5: 1-50.

Monterosato T. A. 1877 a. - Note sur quelques coquilles provenant des côted d'Algerie. Journal de Conchyliologie 25 (1): 24-49, 2 pls. http://biodiversitylibrary.org/page/16223236

Monterosato T. A. 1877b. - Catalogo delle conchiglie fossili di Monte Pellegrino e Ficarazzi presso Palermo. Bollettino Regio Comitato Geologico d'Italia (1-2): 28-42.

Monterosato T. A. 1877c. - Notizie sulle conchiglie della rada di Civitavecchia. Annali del Museo Civico di Genova 9: 407-428.

Monterosato T. A. 1878. - Enumerazione e sinonimia delle conchiglie mediterranee. Giornale Scienze Naturali ed Economiche, Palermo 13: 61-115. http://biodiversitylibrary.org/page/35333762

Monterosato T. A. 1884. - Nomenclatura generica e specifica di alcune conchiglie mediterranee. Stabilimento Tipografico Virzì, Palermo, 152 p. https://www.biodiversitylibrary.org/ page/35367233

Monterosato T. A., 1890. - Conchiglie della profondità del mare di Palermo. Il Naturalista Siciliano 9 (8): 181-191. http:// biodiversitylibrary.org/page/11568606

Muñoz Ferrera de Castro J. L., Hernández J., Ríos Jiménez F., Martínez Chacón M., Torres Alba J. S. \& Meneses SORES V. 2019. - Guia de los moluscos marinos y continentales del Campo de Gibraltar. Editorial Ornitour, Cadiz, 401 p.

Nam H. H., Corneli P. S., WatKins M., Olivera B. \& BandyoPADHYAY P. 2009. - Multiple genes elucidate the evolution of venomous snail-hunting Conus species. Molecular Phylogenetics and Evolution 53 (3): 645-652. https://doi.org/10.1016/j. ympev.2009.07.013

NARDO G. D. 1847. - Sinonimia Moderna delle Specie Registrate nell'Opera Intitolata: Descrizione de' Crostacei, de' Testacei e de' Pesciche Abitano le Lagune e Golfo Veneto Rappresentati in Figure, A chiaro-scuro ed a Colori dall'Abate Stefano Chiereghini Ven. Clodiense. Antonelli, Venezia, xi + 128 p. https://doi.org/10.5962/bhl.title.120206

Negri M. P. \& CoRSElli C. 2016. - Bathyal Mollusca from the cold-water coral biotope of Santa Maria di Leuca (Apulian margin, southern Italy). Zootaxa 4186: 1-97. https://doi.org/10.11646/ zootaxa.4186.1.1

Nobre A. 1931. - Moluscos Marinhos de Portugal. Instituto de Zoologia da Universidade do Pôrto, Pôrto, 466 p., pls. 13-80.

Nobre A. 1936. - Moluscos Marinhos de Portugal. Vol. 2. Instituto de Zoologia da Universidade do Pôrto, Pôrto, vii + 378 p., 6 pls.

Nobre A. 1938. - Fauna malacológica de Portugal: Moluscos marinhos e das águas salobras, Volume 1: Moluscos marinhos e das águas salobras. Instituto de Zoologia da Universidade do Pôrto, Porto, xxxii, $806+(2)+$ xix p., 87 pls.

NorDSIECK F. 1968. — Die Europäischen Meeres-Gehäuseschnecken (Prosobranchia) vom Eismeer bis Kapverden und Mittelmeer. Gustav Fischer, Stuttgart, VIII + 273 p.

NordsieCK F. 1977. - The Turridae of the European Seas. La Piramide, Roma, 131 p., 26 pls.

Nordsieck F. \& GarCía-Talavera F. 1979. - Moluscos Marinos de Canarias y Madera (Gastropoda). Aula de Cultura, Tenerife, 208 p., 46 pls.
Norman A. M. 1879. - The mollusca of the fiords near Berge Norway. Journal of Conchology 2: 8-77.

Norman A. M. 1899. - Revision of British Mollusca. Annals and Magazine of Natural History, series 74: 126-152.

NYST P. H. 1878. - Conchyliologie des terrains Tertiaires de la Belgique. Ire. Terrain Pliocène Scaldisien. Annales du Musée Royal d'Histoire Naturelle de Belgique, série Paléontologique 3 (Atlas): 28 pls.

NYST P. H. 1881. - Conchyliologie des terrains Tertiaires de la Belgique, Ire. Terrain Pliocène Scaldisien. Annales du Musée Royal d'Histoire Naturelle de Belgique, série Paléontologique 3 (text): 1-263.

OdHner N. H. 1931-1932. - Beiträge zur Malakozoologie der Kanarischen Inseln. Lamellibranchien, Cephalopoden, Gastropoden. Arkiv for Zoologi 23A (14): 1-116.

Olabarria C., Urgorri V. \& Troncoso J. S. 1999. — Trophic structure of the molluscan fauna in the inlet of Baño (NW Spain): distribution, ordination and relationship to environmental parameters. Bollettino Malacologico 34 (5-8): 87-96.

Oliver Baldoví J. D. 2007. - Checklist of the marine testaceous gastropods in the southern part of the Gulf of Valencia (Spain). Iberus 25 (2): 29-61. https://www.biodiversitylibrary. org/page/42380528

Oliver J. D., Calvo M., Guallart J., Sanchez-Tocino L. \& TEMPLADO J. 2015. - Gasteropódos marinos de las islas Chafarinas (Meditérraneo suroccidental). Iberus 33 (1): 97-150.

Oliver J. D., Templado J. \& Kersting D. K. 2012. — Gasteropodos marinos de las islas Columbretes (Mediterraneo occidental) Iberus 30 (2): 49-87.

Oliverio M. 1997. - Biogeographical patterns in the developmental strategies of gastropods from Mediterranean Posidonia beds. Bollettino Malacologico 32 (1-4): 79-88.

Oliverio M. \& MARiotTini P. 2001. - A molecular framework for the phylogeny of Coralliophila and related muricoids. Journal of Molluscan Studies 67: 215-224. https://doi.org/10.1093/ mollus/67.2.215

Orlando V. E. \& Palazzi S. 1985. - Malacofauna del Golfo di Castellamare (Sicilia). Il Naturalista Siciliano, serie 49: 29-77.

OstroumofF A. 1896. - Otchet o dragirovkah i planktonniyh ulovaht ekspeditsia "Selyanika”. Bulletin de l'Academie Imperiale des Sciences de St. Petersbourg 5: 33-92 [in Russian].

ÖZTÜrk B., Buzzurro G. \& Benli H. 2004. — Marine mollusks form Cyprus: New data and Checklist. Bollettino Malacologico 39 (5-8): 49-78

Pallary P. 1900. - Coquilles marines du littoral du Départment d'Oran. Journal de Conchyliologie 48: 211-422, pls. 6-8. http:// biodiversitylibrary.org/page/25146965

Pallary P. 1912. - Catalogue des mollusques du littoral Méditerranéen de l'Égypte. Mémoires de l'Institut d'Égypte 7 (3): 69-207, pls. 15-18. http://digi.ub.uni-heidelberg.de/diglit/meminstitutegyptien 1914

PanetTa P. \& Imperatrice M. 1994. - Analisi dei molluschi del Banco dell'Amendolara. Bollettino Malacologico 30 (1-4): 33-42.

ParenZAN P. 1970. - Carta d'identità delle conchiglie del Mediterraneo, volume primo Gasteropodi. Edizioni Bios Taras, Taranto, 283 p.

PASTeur-Humbert C. 1962. - Les mollusques marins testacés du Maroc. Catalogue non critique. Rabat, $245+184$ p., $42+39$ pls.

Paulus M. \& Mars P. 1942. - Guide malacologique des environs de Marseille. Deuxième partie (suite et fin). Catalogue des principaux mollusques marins du Golfe de Marseille. Gastéropodes (suite et fin), scaphopodes, pélécypodes, céphalopodes. Bulletin du Muséum National d'Histoire Naturelle de Marseille 2: 71-120.

Peñas A. \& Giribet G. 2003. - Adiciones a la fauna malacologica del litoral del Garraf (NE de la Penísula Ibérica). Iberus 21 (1): 177-189.

Peñas A., Rolán E., Luque A. A., Templado J., Moreno D., Rubio F., Salas C., Sierra A. \& Gofas S. 2006. - Moluscos marinos de la isla de Alboran. Iberus 24 (1): 23-151. 
Peñas A., Rolán E. \& Almera J. 2009. - Fauna malacologica de un fondo detrítico fangoso en el Maresme, Barcelona (Nordeste de la Péninsula Ibérica). Iberus 27 (1): 19-56.

Petit de la Saussaye S. 1852. - Suite et fin du Catalogue des coquilles marines des côtes de France. Journal de Conchyliologie 3 : 176-207.

Petit de la Saussaye S. 1869. - Catalogue des Mollusques Testacées des Mers d'Europe. F. Savy, Paris, 312 p. https://gallica.bnf.fr/ ark:/12148/bpt6k57731605

Peyrot A. 1938. - Les mollusques testacés univalves des dépots Helvétiens du Bassin Ligérien. Catalogue critique, descriptive et illustré. Actes de la Société Linnéenne de Bordeaux 89: 5-361. https://doi.org/10.5962/bhl.title.147213

PHILIPPI R. A. 1836. - Enumeratio molluscorum Siciliae cum viventium tum in tellure tertiaria fossilium, quae in itinere suo observavit. Vol. 1. Schropp, Berlin [Berolini], xiv + 267 p., XII pls. https:// doi.org/10.5962/bhl.title.100735

Philippi R. A. 1844. - Enumeratio molluscorum Siciliae cum viventium tum in tellure tertiaria fossilium, quae in itinere suo observavit. Volumen secundum continens addenda et emendanda, nec non comparationem faunae recentis Siciliae cum faunis aliarum terrarum et com fauna periodi tertiariae. Eduard Anton, Halle [Halis Saxorum], iv + 303 p., pls. XIII-XXVIII.

PIANI P. 1980. - Catalogo dei molluschi conchiferi viventi nel Mediterraneo. Bolletino della Malacologico 16 (5-6): 113-224.

Poppe G. T. \& Goto Y. 1991. — European Seashells. Volume 1 (Polyplacophora, Caudofoveata, Solenogastra, Gastropoda). Verlag Christa Hemmen, Wiesbaden, 352 p.

Potiez V. L. V. \& Michaud A. L. G. 1838. - Gallerie des mollusques, ou catalogue méthodique, descriptifet raisonné des mollusques et coquilles du Muséum de Douai. J.-B. Bailliére, Paris, Vol. 1: xxxvi + 560 p. +[i-iv, errata]; Atlas: 1-56, pl. 1-37.

Powell A. W. B. 1966. - The molluscan families Speightiidae and Turridae an evaluation of the valid taxa, both Recent and fossil, with lists of characteristic species. Bulletin of the Aukland Institute and Museum 5: 1-184, 23 pls.

PrIOlO O. 1967. - Nuova revisione delle conchiglie marine di Sicilia - Memoria XVIII. Atti Accademia Gioenia Scienze Naturali, Catania, serie V. Vol. 19: 667-718, 1 pl.

Prkić J., GiannuZZi-SaVelli R., Pusateri F., Russini V., Fassio G. \& Oliverio M. 2000. - Three new species of Raphitoma Bellardi, 1847 (Mollusca, Gastropoda, Raphitomidae) from Croatian waters (NE Adriatic Sea). Zoosystema 42 (16): 215-237. https:// doi.org/10.5252/zoosystema2020v42a16

Puillandre N., Lambert A., Brouillet S. \& Achaz G. 2012. ABGD, Automatic Barcode Gap Discovery for primary species delimitation. Molecular Ecology 21(8): 1864-1877. https://doi. org/10.1111/j.1365-294X.2011.05239.x

PusATERi F. \& GiannuZZi-Savelli R. 2008. - A new raphitomine neogastropod from the Mediterranean Sea (Conoidea). Iberus 26: 119-126.

PUSATERI F., GIANNUZZI-SAVELli R. \& BARTOLINI S. 2016. — A revision of the Mediterranean Raphitomidae, 3: on the Raphitoma pupoides (Monterosato, 1884) complex, with the description of a new species (Mollusca Gastropoda). Biodiversity Journal 7(1): 103-115.

Pusateri F., Giannuzzi-Savelli R. \& Bartolini S. 2018. A revision of the Mediterranean Raphitomidae (Gastropoda Conoidea), 6: on the Raphitoma corbis (Potiez et Michaud, 1838). Biodiversity Journal 9 (3): 217-225. https://doi.org/10.31396/ Biodiv.Jour.2018.9.3.217.225

Pusateri F., Giannuzzi-Savelli R. \& Oliverio M. 2012. A revision of the Mediterranean Raphitomidae 1: on the sibling species Raphitoma contigua Monterosato, 1884 and Raphitoma spadiana n. sp. (Gastropoda, Conoidea). Iberus 30(1): 41-52.

Pusateri F., GianNUZZI-SAVElli R. \& Oliverio M. 2013. - A revision of the Mediterranean Raphitomidae 2: on the sibling species Raphitoma lineolata (B.D.D., 1883) and Raphitoma smriglioi n. sp. Iberus 31(1): 11-20.
ReEve L. A. 1843. - Monograph of the Genus Pleurotoma. Conchologia Iconica, or Illustrations of the shells of molluscous animals. Vol. 1. Reeve Brothers, London. Pls. 18, species 1155. [Published JanuaryDecember 1843.]. http://www.biodiversitylibrary.org/page/11119161

Repetto G., Orlando F. \& Arduino G. 2005. - Conchiglie del Mediterraneo. Edizioni Amici del Museo "Federico Eusebio", Alba, $392 \mathrm{p}$.

REQUIEN E. 1848. - Catalogue des coquilles de l'Ile de Corse. Seguin Ainé, Avignon, xii + 13-111 p. [Supplément begins on p. 97]. Requien listed numerous varietal names under many of the nominal taxa he listed. All are nomina nuda and none were mentioned by any subsequent author.

RoBIN A. 2008. - Encyclopedia of Marine Gastropods. ConchBooks, Hackenheim, $480 \mathrm{p}$.

Rolán E. 2005. - Malacological Fauna from the Cape Verde Archipelago. ConchBooks, Hackenheim, 455 p.

ROLÁN E. (ED.) 2011. - Moluscos y conchas marinas de Canarias. Solenogastres, caudofoveata, Polyplacophora, Gastropoda, Bivalvia, cefalópodos y Scaphopoda. Conchbooks, Hackenheim, 588 p., 130 pls. + CD-Rom.

Rolán E., Otero-Schmitt J. \& Fernandes F. 1998. - The family Turridae s. l. (Mollusca, Neogastropoda) in Angola (West Africa), 1. Subfamily Daphnellinae. Iberus, 16, 95-118. http:// biodiversitylibrary.org/page/32629070

RugGieri G. 1967. - Lo stratotipo del piano milazziano. Atti Accademia Gioenia Scienze Naturali, Catania, ser. VIa, 18 (Suppl.), 311-318.

Russini V., Giannuzzi-Savelli R., Pusateri F., Prkić J., Fassio G., Modica M. V. \& Oliverio M. 2020. — Genetic evidence of poecilogony in the genus Raphitoma Bellardi, 1847. Submitted to Invertebrate Systematics 34: 293-318. https://doi.org/10.1071/IS19039

Sabelli B., GiannuZzi-Savelli R. \& Bedulli D. 1990. - Catalogo annotato dei Molluschi marini del Mediterraneo. Vol. 1. Edizioni Libreria Naturalistica Bolognese, Bologna, xiv + 348 p. [Title also given in English "Annotated check-list of Mediterranean marine mollusks"].

SACCO F. 1904. - I Molluschi dei Terreni Terziarii del Piemonte e della Liguria, Parte XXX. Aggiunte e Correzioni. Considerazioni Generali. Indice Generale dell'Opera. Carlo Clausen, Torino, xxxvi + 203 p., 31 pls. http://www.biodiversitylibrary.org/item/46270

SANDRI G. B. \& DANILO F. 1856. - Elenco nominale dei gasteropodi testacei marini raccolti nei dintorni di Zara. Programma dell'Imperiale Regio ginnasio completo di prima classe in Zara (6): 107-151.

SARS G. O. 1878. - Bidrag til Kundskaben om Norges Arktiske Fauna. I. Mollusca Regionis Arcticae Norvegiae. A.W. Brogger, Christiania, xiii + [3] + 466 p., 18 pls. http://www.biodiversitylibrary.org/item/92496

SCACCHI A. 1833. - Osservazioni zoologiche. Napoli, Tipi della società tipografica, Napoli. part I, p. 1-12 (February); part II, p. 13-27 (May). http://biodiversitylibrary.org/page/35752103

SCACCHI A. 1836a. - Notizie intorno alle conchiglie ed a' zoofiti fossili che si trovano nelle vicinanze di Gravina in Puglia. Seconda edizione. Tipografia Fernandes, Napoli, 74 p., 2 pls.

SCACCHI A. 1836b. - Catalogus Conchyliorum Regni Neapolitani quae usque adhuc Reperit. Typis Filiatre Sebetii, Neapoli. 18 p.,1 pl.

SCACCHI A. 1857. - Catalogus Conchyliorum Regni Neapolitani quae usque adhuc Reperit. Typis Francisci Xaverii Tornese, Neapoli, $19 \mathrm{pp}, 1 \mathrm{pl}$. (2nd edition). https://www.biodiversitylibrary.org/ page/34807485

SCALIA S. 1900. - Revisione della fauna postpliocenica dell'argilla di Nizzeti presso Acicastello (Catania). Atti Accademia Gioenia Scienze Naturali Catania, ser. IVa. Vol. 13, mem. 19, 1-26.

SCALIA S. 1907. - Il Postpliocene dell'Etna. Atti Accademia Gioenia Scienze Naturali Catania, ser. IVa. Vol. 20 (mem. 13): 1-43.

Scaperrotta M., Bartolini S. \& Bogi C. 2010. - Accrescimenti - Stadi di accrescimento dei molluschi marini del Mediterraneo. Vol. 2. L'Informatore Piceno, Ancona, 176 p. 
SCAPERrotta M., Bartolini S. \& Bogi C. 2012. - Accrescimenti - Stadi di accrescimento dei molluschi marini del Mediterraneo. Vol. 4. L'Informatore Piceno, Ancona, 184 p.

SEgUENZA G. 1873. - Studi stratigrafici sulla formazione pliocenica dell'Italia meridionale. Bollettino del Regio Comitato Geologico d'Italia, 9-10, 280-301.

SeguenZA G. 1875. - Studi stratigrafici sulla Formazione pliocenica dell'Italia Meridionale. Bollettino del Regio Comitato Geologico d'Italia 7-8: 204-211. [See Bertolaso \& Palazzi, 2000, for an analysis of the work, which appeared in 25 parts.].

SeguenZa G. 1880. - Le formazioni terziarie nella provincia di Reggio (Calabria). Memorie della Classe di Scienze Fisiche Matematiche e Naturali della Regia Accademia dei Lincei, serie 3. Vol. 6: 1-445, 17 pls.

SHIKAMa T. \& HoriKOSHI M. 1963. - Selected shells of the World Illustrated in Colours. Hokuryu-Kan Publishing Co. LTD., Tokyo, [8] + 154 p., 102 pls.

SISMONDA E. 1847. - Sinossi metodica animalium invertebratorum pedemontii fossilium (exceptis inedite inbus). Typis Regiis, Augustae Taurinorum, VIII + 62 p.

SMITH E. H. 1967. - The reproductive system of the British Turridae (Gastropoda: Toxoglossa). The Veliger 10: 176-187.

Soppelsa O., CRocetta F. \& Fasulo G. 2007. - I molluschi marini di Punta di Pioppeto (Isola di Procida - Campania). Bollettino Malacologico 43 (1-8): 21-32.

SOWERBY G. B., II 1859. - Illustrated index of British shells. Containing figures of all the Recent species, with names and other information. Simpkin, Marshall, \& Co., London, xii p., 24 pls. + captions. https://doi.org/10.5962/bhl.title.15936

SPADA G. 1971. - Contributo alla conoscenza della malacofauna della biocenosi a Posidonia oceanica (L.) lungo le coste italiane. Conchiglie 7: 125-134.

Spada G., Sabelli B. \& Morandi V. 1973. - Contributo alla conoscenza della malacofauna marina dell'isola di Lampedusa. Conchiglie 9: 29-67.

STeuer A. 1939. - Die Fischereigründe vor Alexandrien XIX Mollusca. Thalassia 3: 1-143

SYKES E. R. 1906. - On the Mollusca procured during the "Porcupine" expeditions, 1869-1870. Supplemental notes, part III. Proceedings of the Malacological Society of London 7: 173-190, pl. 16. http://biodiversitylibrary.org/page/15797635

TABANElli C. \& SEgurini R. 1994. - Nota preliminare ala malacofauna pliocenica di Rio Albonello (Faenza). Quaderno di Studi e Notizie di Storia Naturale della Romagna 3: 3-22.

TALLACK W. 1861. - Malta under de Phoenicians, Knighths and English. In: Natural History of Malta, p. 142-192.

Templado J. \& Llanso R. 1981. - Turridos (Gastropoda: Prosobranchia) del Cabo de Palos (Murcia). Iberus 1: 33-38.

Terreni G. 1981. - Molluschi conchiferi del mare antistante la costa toscana. Benvenuti \& Cavacioppi, Livorno, 106 p., with 9 pls.

TesCH P. 1912. - Beiträge zur Kenntnis der marinen Mollusken in West-Europäischen Pliocänbecken. Mededeelingen van de Rijksopsporing van Delfstoffen 4: 1-96.

THIELE J. 1929. - Handbuch der Systematischen Weichtierkunde. Vol. 1. Gustave Fischer, Jena, 376 p.

Thiriot-QuiÉvreux C. 1972. - Microstructures de coquilles larvaires de prosobranches au microscope électronique à balayage. Archives de Zoologie Expérimentale et Générale 113:553-564, 7 pls.

Trigo J. E., Diaz Agras G. J., Garcia Alvarez O. L., Perez Dieste J., Rolán Mosquera E., Souza Troncoso J. \& UrGORRI V. 2018. — Guía de los Moluscos Marinos de Galicia. Servizio de Publicacións da Universidade de Vigo., 832 p.
Trono D. 2006. - Nuovi data sulla Malacofauna del Salento (Puglia Meridionale). Bollettino Malacologico 42 (5-8): 58-84.

Trono D. \& MACrì G. 2013. - Malacofauna del Salento (Trono, 2006): Corrigenda e addenda. Bollettino Malacologico 49 (1): 26-48. https://www.biodiversitylibrary.org/page/51214543

Tropeano D., Arduino L., Bosso C. \& Fornaro M. 1984. - Il Pliocene di La Loggia (Torino). Rivista Piemontese Storia Naturale 5: 55-67.

Tryon G. W. JR 1890. — Conidae, Pleurotomidae. Manual of Conchology, Structural and Systematic, with Illustrations of the Species. Vol. 6. Tryon, Philadelphia, 413 p., 34 pls. https://www.biodiversitylibrary.org/page/23626788

VAN AARTSEN J. J. 1988. - Nomenclatural notes, 7. Forbes' Aegean Turridae. Bollettino Malacologico 24 (5-8): 141-144.

VAN AARTSEN J. J. MENKHORST H. P. M. \& GitTENBERGER E. 1984. The marine Mollusca of the Bay of Algeciras, Spain, with general notes on Mitrella, Marginellidae and Turridae. Basteria Supplement 2: 1-135. http://natuurtijdschriften.nl/download?type=d ocument; docid $=645087$

VAN STRAATEN L. M. J. U. 1960. — Marine mollusc shell assemblages of Rhone Delta. Geologie en Mijnbouw, NW. S. 22: 105-129, 6 pls.

Vardala-Theodorou E. \& Nicolaidou A. 2007. - On the Recent and fossil malacofauna of "Vouliagmeni Lake", Peracora (Korinthiakos Gulf, Greece). Bollettino Malacologico 43 (1-8): 62-70. https://www.biodiversitylibrary.org/page/49936845

VAZZANA A. 2010. — La malacofauna del Circalitorale di Scilla (Stretto di Messina). Bollettino Malacologico 46 (2): 65-74. https:// www.biodiversitylibrary.org/page/51117416

VAZZANA A. 2011. - Biodiversità marina lungo le coste della provincia di Reggio Calabria. Laruffa editore, Reggio Calabria, $71 \mathrm{p}$.

Vera-Peláez J. L., Martinell J. \& Lozano-Francisco M. C. 1999. - Turridae (Gastropoda, Prosobranchia) del Plioceno inferior de Málaga (España). Iberus 17: 1-19.

Warén A. 1980. - Marine Mollusca described by John Gwyn Jeffreys, with location of the type material. Conchological Society of Great Britain and Ireland, Special Publication 1:1-60 + 8 pls.

WATSON R. B. 1886. - Report on the Scaphopoda and Gasteropoda collected by the H. M. S. Challenger during the years 1873-76. Report on the Scientific Results of the Voyage of the 'Challenger' (Zoology) 15: 1-756, 50 pls. http://www.19thcenturyscience.org/ HMSC/HMSC-Reports/Zool-42/README.htm

WATSON R. B. 1897. - On the marine Mollusca of Madeira; with descriptions of thirty-five new species and an index-list of all the known sea-dwelling species of that island. Journal of the Linnean Society (London), 26, 233-329. https://doi. org/10.1111/j.1096-3642.1897.tb00033.x

WeinKaufF H. C. 1868. - Die Conchylien des Mittelmeeres, ihre geographische und geologische Verbreitung. T. Fischer, Cassel, 512 p.

WEINKAUFF H. C. 1873. - Catalog der im europäischen Faunengebiet lebenden Meeres-Conchylien. Voigtländer, Creuznach, xvi + 86 p. https://doi.org/10.5962/bhl.title.11775

WenZ W. 1943. - Gastropoda. Prosobranchia. In: Schindewolf, O.H. (Ed.) Handbuch der Paläozoologie. Vol. 6. Gebrüder Borntraeger, Berlin, 1201-1505 pp, figs 3417-4211 [October, 1943]].

Wigham G. D. \& Graham A. 2018. - Marine Gastropoda 3: Neogastropoda. Synopsis of the British fauna no. 62. The Linnean Society of London and Field Studies Council, 206 p.

Zelinskaya V. A., Kulichenko V. G., Makarenko D. E. \& Sorochan E. A. 1968. - Paleontologicheskii Spravochnik. Vol. 2. Brushonogie i Lopatonogie Molluski Paleogena i Miozhena Ukrainiy. Akademija Nauk Ukrainskoj SSR Institut Geologicheskikh Nauk, Kiev, 281 p., 54 pls. 